\title{
Tank Farm Surveillance and Waste Status Summary Report for July 1993
}

Prepared for the U.S. Department of Energy Office of Environmental Restoration and Waste Management

\section{Q Westinghouse \\ Hanford Company Richland, Washington}

Hanford Operations and Engineering Contractor for the

U.S. Department of Energy under Contract DE-AC06-87RL10930 


\section{LEGAL DISCLAIMER}

This report was prepared as an account of work sponsored by ari agency of the United Slates Government. Neither the United Stales Government nor any agency thereof, nor any of their employees, nor any of their contractors, subcontractors or their employees, makes any warranly, express or implied, or assumes any legal liability or responsibility for the accuracy, completeness, or any third party's use or the results of such use of any information, apparatus, product, or process disclosed, or represents that its use would not infringe privately owned rights. Reference herein to any specific commercial product, process, or service by trade name, trademark, manufacturer, or otherwise, does not necessarily constitute or imply its endorsement, recommendation, or fave-ing by the United States Government or any agency there of or its contractors or subcontractors. The views and opiniens of authors expressed herein do not necessarily state or reflect those of the United States Government or any agency thereot.

This report has been reproduced from the best available copy Available in paper copy and microtiche.

Available to the U.S. Department of Energy and its contractors from

Otfice of Scientific and Technical Information

P.O. Box 62

Oak Ridge, TN 3783

(615) $576-8401$

Available to the oublic from the U.S. Department of Commerce National Technical Information Service

5285 Port Royai fioad

Springlield, VA 22161

(703) 487.4650

Prinled in the United Stales of America

DISCLM-1.CHP $\{1.91\}$ 


\section{Tank Farm Surveillance and Waste Status Summary Report for July 1993}

B. M. Hanlon

Date Published

November 1993

Prepared for the U.S. Department of Energy Office of Environmental Restoration and Waste Management

\footnotetext{
(2) Westinghouse

P.O. Box 1970

Hanford Company Richland, Washington 99352

Hanford Operations and Engineering Contractor for the

U.S. Department of Energy under Contract DE.AC06-87RL10930
} 


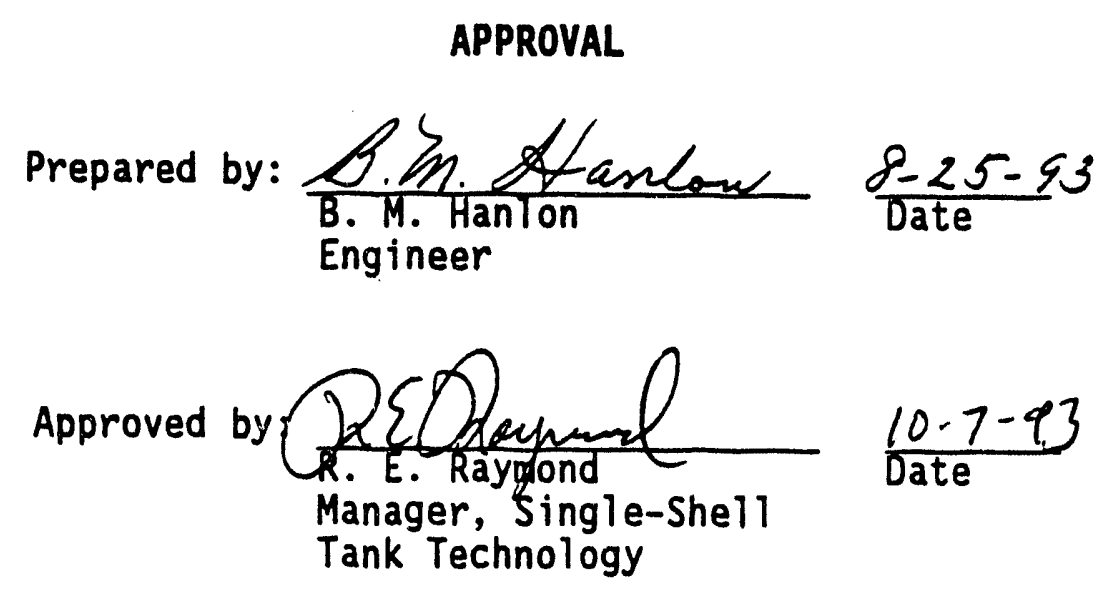




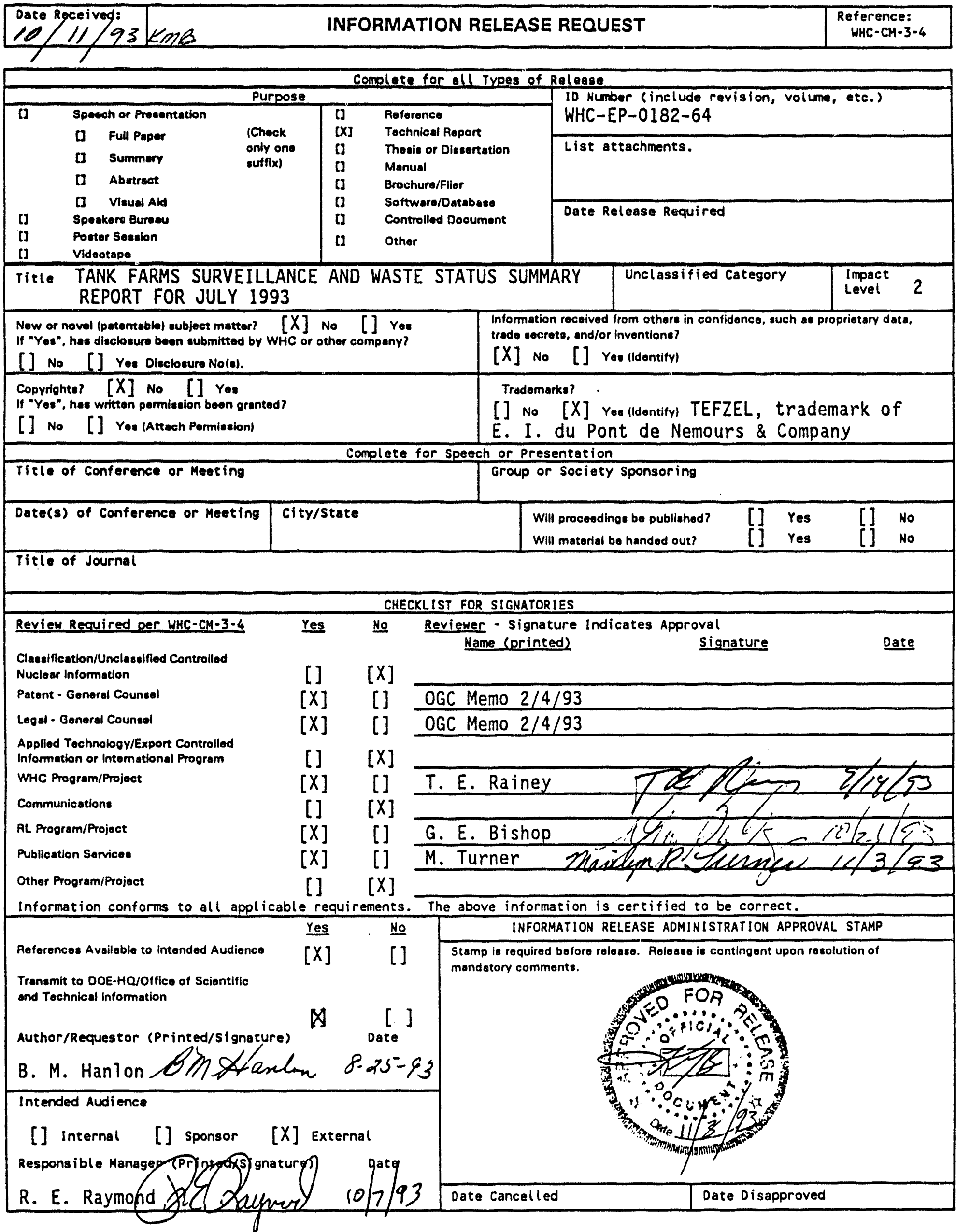




\title{
WHC-EP-0182-64
}

\section{TANK FARM SURVEILLANCE AND WASTE STATUS}

SUMMARY REPORT FOR JULY 1993

\author{
E. M. Hanlon
}

\begin{abstract}
This report is the official inventory for radioactive waste stored in underground tanks in the 200 Areas at the Hanford Site. Data that depict the status of stored radioactive waste and tank vessel integrity are contained within the report. This report provides data on each of the existing 177 large underground waste storage tanks and 49 smaller catch tanks and special surveillance facilities, and supplemental information regarding tank surveillance anomalies and ongoing investigations. This report is intended to meet the requirement of U. S. Department of Energy-iichland Operations office Order 5820.2A, Chapter I, Section 3.e. (3) (DOE-RL, 1990, Radioactive Waste Management, U. S. Department of Energy-Richl and Operation Office, Richland, Washington) requiring the reporting of waste inventories and space utilization for Hanford Tank Farm Tanks.
\end{abstract}


WHC-EP-0182-64

This page intentionally left blank. 
SUMMARY

I. WASTE TANK STATUS

II. WASTE TANK INVESTIGATIONS

III. SURVEILLANCE AND WASTE TANK STATTUS HIGHLIGHTS $\cdots \cdots \cdots \cdots$

\section{Appendixes:}

A. WASTE TANK SURVEILLANCE MONITORING TABLES . . . . . . . . . A A-1

Tables:

1 Watch List Tanks ................. . . A-3

2 Tanks Containing $>1000$ Gram Mole of Ferrocyanide . . . . . A-5

3 Tanks With Potential for Hydrogen or Flammable Gas Accumulation above the Flammability Limit . . . . . . . A-7

4 Single-She1l Tanks Containing Concentrations of Organic Salts . A-8

5 Single-She11 Tanks With High Heat Loads $(>40,000 \mathrm{Btu} / \mathrm{h})$. . . . A-9

6 Non-Watch !ist Low Heat List Tanks $(<40,000 \mathrm{Btu} / \mathrm{h}) \ldots . . .$. A-11

7 Single-Shell Tanks Monitoring Compliance Status . . . . . . . A-14

8 Double-Shell Tanks Monitoring Compliance Status . . . . . . . A-19

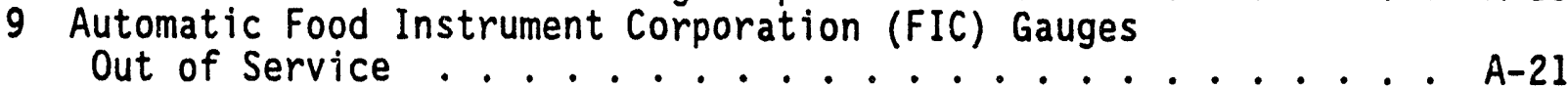

B. DOUBLE-SHELL TANK WASTE TYPE AND SPACE ALLOCATION ......... B-1 Tables:

1 Double-Shell Tank Waste Type and Space Allocation ...... B-3

2 Double-She'l Tank Waste Inventory ........... B-14 Figures:

1 Current atus and Contingency Space for the 242-A

Evaporator Restart ............... B-4

2 Total Available Usable Tank Space . . . . . . . . . B-5

3 Priority Space Availablity and Usage .......... B-6

4 Comparison of Monthly Average Waste Generation to Management Limit by Facility . . . . . . . . . . . B-7

5 PUREX Monthly Waste Generations . . . . . . . . . . . . B-8

6 Tank Farm Monthly Waste Generations . . . . . . . . . . B-9

7 B Plant Monthly Waste Generations . . . . . . . . . . B-10

8 T Plant Monthly Waste Generations . . . . . . . . . . . B-11

9 S Plant Monthly Waste Generations ............. B-12

10300 Area Monthiy Waste Generations . . . . . . . . . . . B-13

C. TANK AND EQUIPMENT CODE AND STATUS DEFINITIONS .......... c-1

1 Tank and Equipment Code/Status Definitions ......... C-3

D. TANK FARM CONFIGURATION, STATUS AND FACILITY CHARTS . . . . . . D D-1 Figures:

I High-Level Waste Tank Configuration .......... D-3

2 Double-Shell Tank Instrumentation Configuration ...... D-4

3 Single-Shell Tank Instrumentation Configuration ...... D-

4 Double-Shell Tank Status .............. D-7/8

5200 E Single-Shell Tank Status . . . . . . . . . . . . D-9/10

$6200 \mathrm{~W}$ Single-Shel1 Tank Status .......... . . D-11/12

7 Hanford Tank Farms Facilities Chart: 200-West Area . . . . . D-13/14

8 Hanford Tank Farms Facilities Chart: 200-East Area . . . . . D-15/16 
WHC-EP-0182-64

This page intentionally left blank. 
E. MONTHLY SUMMARY . . . . . . . . . . . . . . . . . . E-1 Tables:

1 Monthly Summary . . . . . . . . . . . . . . . E-3

2 Tank Use Summary . . . . . . . . . . . . . . . . E-4

3 Inventory Summary by Tank Farm . . . . . . . . . . . . E-5

4 Inventory and Status by Tank - Double-Shell Tanks . . . . . . E-6

5 Inventory and Status by Tank - Single-She1l Tanks . . . . . . . E-9

F. PERFORMANCE SUMMARY .................... F-1

Table:

1 Performance Summary . . . . . . . . . . . . . F-3

G. PUMPING RECORD/LIQUID STATUS AND PUMPABLE LIQUID REMAINING IN TANKS . . G-1 Tables:

1 Pumping Record . . . . . . . . . . . . . . . . . . G G-3

2 Liquid Status and Pumpable Liquid Remaining in Tanks . . . . . . G-4

H. CATCH TANKS AND SPECIAL SURVEILLANCE FACILITIES . . . . . . . . H-1 Tables:

1 East and West Area Catch Tanks and Special

Surveillance Facilities (Active) . . . . . . . . . . . H-3

2 East Area Catch Tanks and Special Surveillance

Facilities (Inactive) ................ H-4

3 West Area Catch Tanks and Special Surveillance

Facilities (Inactive) ............... H-5

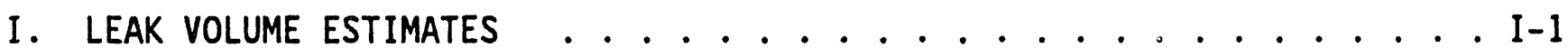

Table:

1 Single-Shell Tank Leak Volume Estimates . . . . . . . . . . I-3

\begin{tabular}{|l|l|l|}
\hline \multicolumn{3}{|c|}{ METRIC CONVERSION CHART } \\
\hline 1 inch & $=$ & 2.54 centimeters \\
\hline 1 foot & $=$ & 30.48 centimeters \\
\hline 1 gallon & $=$ & 3.80 liters \\
\hline 1 ton & $=0.90$ metric tons \\
\hline & ${ }^{\circ} \mathrm{F}=\left(\frac{9}{5}{ }^{\circ} \mathrm{C}\right)+32$ \\
\hline \\
1 Btu/h \\
$($ International Table)
\end{tabular}


WHC-EP-0182-64

This page intentionally left blank 
WHC-EP-0182-64

\section{TANK FARM SURVEILLANCE AND WASTE STATUS SUMMARY \\ REPORT FOR JULY 1993 \\ SUMMARY}

Note: Changes from the previous month are in bold print.

\section{WASTE TANK STATUS}

\begin{tabular}{|c|c|c|}
\hline Category & Quantity & Date of Last Change \\
\hline In-Service Tanks ${ }^{c}$ & 28 double-shell & $10 / 86$ \\
\hline Out-of-Service Tanks & 149 single-shell & $07 / 88$ \\
\hline Assumed Leaker Tanks ${ }^{f}$ & 67 single-shell & $7 / 93$ \\
\hline Sound Tanks & $\begin{array}{l}28 \text { double-shel1 } \\
82 \text { single-shell }\end{array}$ & $\begin{array}{l}1986 \\
7 / 93 \\
\end{array}$ \\
\hline Interim Stabilized Tanks ${ }^{b, d}$ & 106 single-shell & $04 / 93$ \\
\hline Not Interim Stabilized ${ }^{f}$ & 43 single-shell & $04 / 93$ \\
\hline Intrusion Prevention Completed & 98 single-shell & $09 / 91$ \\
\hline $\begin{array}{l}\text { Watch List Tanks } \\
\text { Total }\end{array}$ & $\begin{array}{l}44 \text { single-shell } \\
6 \text { double-she11 } \\
50 \text { tanks }\end{array}$ & $\begin{array}{l}7 / 93^{h} \\
6 / 93 \\
7 / 93\end{array}$ \\
\hline
\end{tabular}

although all 149 single-shell tanks were removed from service (i.e., no longer authorized to receive waste) as of November 21, 1980, the category of "Out-of-Service" was not established until July 1988.

b of the 106 tanks classified as interim stabilized, 59 are listed as assumed leakers. The total of 106 interim stabilized tanks includes eight tanks that do not meet current establ ished supernatant and interstitial liquid stabilization criteria: B-104, B-107, B-110, B-111, BX-110, T-102, T-112, and U-110. (These tanks did meet the criteria in existence when they were declared interim stabilized; B-107, B-110, $B-111, B X-110$ and $U-110$ are assumed leakers but surveillance data do not show an indication of a cont inuing (eak.)

c six double-shell tanks listed as "in service" are currently included on the Hydrogen Watch List and are thus prohibited from receiving waste in accordance with "Safety Measures for Waste Tanks at Hanford Nuclear Reservation," Section 3137 of the National Defense Authorization Act for Fiscal Year 1991. November 5, 1990, Public Law 101-510.

d of the 44 single-shell tanks on Watch Lists, 19 have been Interim Stabilized.

e of the 44 single-shell tanks on Watch Lists, 28 have completed Intrusion Prevention (this category replaced Interim Isolation). See Appendix C, Tank and Equipment Codes and Status Definitions, for "Intrusion Prevention" definition.

f Eight of the tanks are both assumed leakers and not Interim Stabilized. See Appendix I, Leak Volume Estimates, for more details. Tank SX-102 was declared an assumed leaker in May, and reclassified as Sound in July, 1993. See "Waste Tank Investigations" section, of the July 1993 report for more details.

9 See Tables A-1 through A-5 for more information on Watch List Tanks. Three tanks are currently on more than one Watch List.

$h$ Dates for the Watch List tanks ore "officially added to the Warch List" dates. See Table A-1, - Watch List Tanks, for further information. 


\section{WASTE TANK INVESTIGATIONS}

This section includes all single-shell tanks or catch tanks on the Alert List for surface level or interstitial liquid level (ILL) decreases, or for drywell/lateral radiation level increases.

There were no tanks under investigation for surface or ILL decreases or for drywe11/lateral radiation increases during July 1993.

A. Assumed Leakers or Assumed Re-leakers: (See Appendix C for definition of "Re-leaker")

This section includes all single- or double-shell tanks or catch tanks for which an off-normal or unusual occurrence report has been issued for assumed leaks or re-leaks. Tanks/catch tanks will remain on this list until either a) completion of Interim Stabilization, or b) the updated occurrence report indicates that the tank/catch tank is not an assumed leaker.

Tank 241-BX-111. The surface level showed a slow erratic increasing trend since 1986. The level had increased approximately 1.00 inch from the reference baseline of 79.00 inches. A decreasing trend was observed during February 1993, but has since remained stable, fluctuating between 78.75 and 79.00 inches. The decrease criteria for this tank is 1.00 inch from the reference baseline. The liquid observation well (LOW) interstitial liquid level (ILL) was stable as of Apri1 1, 1993. In-tank photographs were taken July 16, 1993. Figure 1, Tank 241-BX-111 In-Tank Photo, shows the location of two saltwell screens and an LOW. There appears to be approximately $90 \% 1$ iquid surface with about $10 \%$ floating solids.

- Resolution status: When this tank was under investigation, preliminary notifications were made to regulatory agencies on March 24 and April 16, 1993. Preparations to begin emergency pumping were initiated in late March. This tank was declared an assumed re-leaker on April 30, 1993. Upon completion of pumping, the surface level baseline for the tank will be adjusted.

Significant accomplishments were made in July toward emergency pumping this tank: pressure testing of transfer lines in the BX Farm was successfuily completed; all maintenance-related work packages were completed except for the 244-BX Transfer Tank; liquid sampling from both the BX-110 and 111 tanks was completed; pressure switch calibration and installation on jet pumps on both tanks were completed; pump tests on the BX-110 jet pump were successfully done; and the Final Readiness Review Checklist sign-off was begun. Tanks 241BX-110 and 111 were removed from the ferrocyanide Watch List on July 9, 1993, on the basis that the tanks sontain <1000 gm moles of ferrocyanide. See Highlights, item $\# 2$.

Tank 241-SX-102. The quarterly LOW reading taken Apri1 30, 1993, indicated a decrease of 0.2 feet from the established baseline. The rerun requested and taken on May 5, 1993, indicated a decrease of 0.3 feet which equals the established decrease criteria. Previous neutron LOW readings had been stable, fluctuating between the baseline and a 0.2-foot decrease, but the May 5, 1993, reading was the first indication of a 0.3 foot or larger decrease. An OffNormal Report was issued at that time and the LoW frequency was increased from quarterly to weekly. The neutron LOW is the primary means of liquid level detection as this tank has a solid surface. The LOW readings taken on May 20 , 1993, indicated a further decrease to 0.4 feet below the established baseline. The previous Off-Normal was upgraded to an Unusual Occurrence Report, and 
proper notifications were initiated. Because of the recently observed decreasing trend, this tank was declared an "assumed leaker" on May 20, 1993. The LOW readings taken on June 30, 1993, indicated a further decrease to 1.0 feet below the established baseline. However, an improved method for measuring the ILL using LOW data has been under development. This new method does not show a recent decreasing trend. Using the improved method, Westinghouse Hanford (WHC) and Pacific Northwest Laboratories (PNL) have reevaluated the LOW data. This re-evaluation indicated that the ILL has been on a very steady decline since at least 1987, with no acceleration of the estabi ished decrease rate. Similar constant rates of decline in ILLs are also seen in other tanks, with the decreases normally being attributed to evaporation. An evaporation study performed by WHC Waste Characterization Analysis arrived at estimated evaporation rates closely matching those seen in the revised LOW analyses. After reviewing all available information, there are no surveillance data which would indicate a loss of liquid attributed to a breach of integrity at this time. Tank 241-SX-102 meets the definition of a sound tank, and has been reclassified from "Assumed Leaker" to "Sound." See Highlights item \#8, Occurrence Report RL-WHC-TANKFARM-1993-0044. This tank will no longer appear in this report, unless conditions change to warrant its inclusion.

\section{B. Tanks with increases indicating possible intrusions:}

This section includes all single-shell tanks for which the surveillance data shows that the surface level or ILL has met or exceeded the increase criteria (this section does not include all tanks on the Alert List because the intrusion criteria for the Alert List is $\underline{50 \%}$ of the increase criteria).

Tank 241-B-202. A steady increase in the surface level measurement has been observed since December 1984. The manual tape pencil plummet is contacting 1 iquid. When the quarterly reading was obtained on October 6,1992 , the level was recorded as 144.75 inches, thus exceeding the 2.00 -inch increase criteria from the established baseline of 142.50 inches. The surface level measurement was rechecked on October 9, 1992, (145.50 inches) and October 13 (145.00 inches), verifying the increase and that the criteria had been exceeded. The surface level continues to show an increase and is at 145.25 inches for June 1993. The monitoring frequency has been increased from quarterly to monthly. Occurrence Report RL-WHC-TANKFARM-1993-0024 was issued February 13, 1993. The tank was administratively stabilized in May 1985.

Resolution status: A photo package was initiated on May 11, 1993, to investigate the possibility of an intrusion. Review of previous photos was inconclusive. New photos are required to determine the actual supernatant increase, if any. A temporary baseline was established at 145.25 inches, until the new photos are available. The surface level in this tank is below the $50 \%$ action criteria based on the temporary baseline; therefore, the tank has been removed from the Alert List.

Tank 241-BX-103. On January 18, 1993, the surface level measurement in 103-BX exceeded the 0.50 -inch increase criteria from the reference baseline of 19.50 inches, and was verified on January 20, 1993. The surface level measurement is currently at 20.40 inches. This tank has shown an erratic increase in surface level measurements since January 6, 1986. Discrepancy Report S\&DA 93522 was issued January 21, 1993. Occurrence Report RL-WHC-TANKFARM-1993-0036 was issued March 25, 1993. The FIC plummet is contacting liquid as indicated by in-tank photographs taken October 31, 1986. Tank 241-BX-103 is Sound, and Interim Stabilized/Intrusion Prevention completed. 
Resolution status: The current level is greater than that prior to stabilization in November 1983. The tank was previously determined to have experienced an intrusion from 1977 to March 1983 (prior to stabilization). Subsequent isolation was expected to halt the intrusion, however, the intrusion is apparently ongoing. A work package was initiated on May 11 , 1993, to re-seal pits and risers and to obtain in-tank photos. The photos will be used to assess the current stabilization status of the tank. A visual survey of the area was performed to determine possible paths for precipitation to enter the tank. The weather covering on the pits and risers was found in place and undamaged. The existing grade is level and revealed no obvious draining problems. Ongoing design/isolation drawing review revealed that nozzles, floor drains and some transfer lines entering the heel pit have been left open. Whether precipitation can enter these lines or condensation can form in sufficient quantities is yet to be determined. These possibilities will be investigated. Photos are expected to be available for review by March 1994.

Tank 241-BY-105. The LOW ILL has shown a slow increasing trend since 1986. The ILL is at the 0.4-foot increase criteria from the reference baseline of $13.50 \mathrm{ft} .$, as of June 30,1993 . The surface level manual tape does not show an increase. Discrepancy Report S\&DA-93-561 was issued June 15, 1993.

Resolution Status: The surface level and ILL are displaying behavior similar to $T X-113$ and $T X-115$. The ILL is showing an increase, while the surface level measurement is showing a decrease. This phenomena could be due to either solids dissolution or formation of a depression in the solids beneath the plummet in conjunction with an intrusion. Review of previous photos indicates the liquid volume is increasing, although it cannot be verified that the solids level is decreasing. A photo package was initiated to investigate the possibility of intrusion, or solids dissolution. Photos are expected to be available for review by July 1994. This tank is on the ferrocyanide Watch List.

Tank 241-S-103. The FIC was out of service from March 8 to May 14, 1993. The surface level increased from 104.15 inches on March 8 to 104.80 inches after FIC repair on May 14, 1993. The level is at the increase criteria. The LOW, last scanned July 22, 1993, has remained stable.

Resolution status: After recalibration of the FIC on June 7, 1993, the surface level (SL) remains stable at approximately 104.65 inches, The SL shows a general increase since 1981. Review of tank level history has also shown the SL to show sudden increases following calibration. Recalibration has normally returned the SL to previous levels. Since the SL currently remains high after recalibration, it is possible that the SL has indeed reached the action criterion for this tank. A photo package for in-tank photos was initiated to investigate the possibility of an intrusion. Photos are expected to be available for review by September 1994.

Tank 241-TX-113. The LOW ILL has shown a slow increase since March 12, 1986, with both the neutron and gamma probes. This tank appeared on the Alert List in 1989, when the ILL reached 50\% of the 0.4-foot increase criteria, but was removed in 1990 when the ILL appeared stable for longer than a 12-month period. The scan data on February 5, 1993, showed the ILL to be 5.5 foot and at the 0.4-foot increase criteria from the reference baseline. S\&DA Discrepancy Report 93-534 was issued March 10, 1993. The LOW was last scanned July 30, 1993, and showed the ILL to be 0.3 feet above the baseline. Resolution status: The technical evaluation of this tank was completed 
April 14, 1993. The results were inconclusive, with recommendation to accelerate the October 1997 waste characterization of the tank. This characterization is expected to confirm that solids are dissolving, causing an increase in ILL. Acceleration of waste characterization is not possible. Watch List tanks have first priority for core sampling. The photo package has been written; photos are expected to be available for review by February 1994. LOW scans and surface level readings have been increased from a quarterly to a monthly frequency. Observation and monitoring will continue.

Tank 241-TX-115. The LOW ILL is exceeding the 0.4-foot increase criteria from the reference baseline. This tank has been on report since 1988, when the increase criteria was first exceeded. Comparison of past and present in-tank photographs show no significant change in surface conditions or obvious evidence of intrusion. Surveillance Deviation Report \#88-08 was issued on May 18, 1988, and Event Fact Sheet \#TF-EFS-88-140 was issued October 27, 1988. This tank appeared on the Executive Summary Report and Alert List until December 31 , 1991, when the report was discontinued. The ILL continues to show an increase with both the neutron and gamma probes. The LOW was last scanned July 30, 1993, and showed a 1.3-foot increase from the baseline. Resolution status: The technical evaluation of the alert condition in this tank was completed April 14, 1993. The results were inconclusive, with recommendation to accelerate the October 1997 waste characterization. Waste characterization is expected to confirm that solids are dissolving, causing an increase in ILL. Acceleration of waste characterization is not possible for non-Watch List tanks. The 1981 photos show evidence of rain intrusion through a central pump pit riser. However, it cannot be concluded from the 1988 photos that the intrusion is ongoing. A photo package was initiated and photos are expected to be available for review by February 1994. This tank will be included in the waste characterization with 113-TX. LOW scans and surface level readings have been increased from a quarterly to a monthly frequency.

Tank 241-TY-102. On November 8, 1992, the automatic FIC surface level measurement of 32.10 inches exceeded the 0.50 -inch increase criteria from the reference baseline of 31.40 inches. Discrepancy Report S\&DA-92-489 was issued November 9, 1992. The tank has a history of icicle buildup on the FIC plummet and intrusions. The surface level measurement was 31.80 inches as of June 30 , 1993. The increase criteria of 0.50 inches is considered to be an extremely tight tolerance for this tank. The FIC readings are erratic, causing the tank to go on alert unnecessarily. The general trend of the data is level.

Revising the increase criteria to 2.0 inches, which is more in 1 ine with other tanks that exhibit similar erratic surface level behavior, has been proposed for this tank. Tank 241-TX-102 is not currently on the Alert List.

Resolution status: This tank is experiencing an ongoing intrusion as is evident by comparison of November 1984 photos with July 1987 photos and an increasing trend in surface level data. A visual survey was conducted to determine possible paths for precipitation to enter the tank. The grade around the tank is level and weather covering is on the pits and intact. The photo package, initiated on May 17, 1993, will be required to assess the current stabilization status of the tank, and to assist in determining the possible paths of intrusion. Ongoing design/isolation drawing review revealed that nozzles, floor drains and some transfer lines entering the pump pit have been left open. Whether precipitation can enter these lines or condensation can form in sufficient quantities is yet to be determined. These possibilities will be investigated. 
Vent Station Catch Tank. The zip cord surface level reading exceeds the maximum operating limit of 36.00 inches. The manual tape has been out of service since July 7, 1992. A temporary zip cord was installed December 16, 1992. The level was 45.50 inches which exceeded the active tank 1 imit of $50 \%$ volume of 40 inches (400 gallons). Transfers are not permitted until the tank is pumped and the level is within limits. Discrepancy Report S\&DA-92-511 was issued December 24, 1992. A new calibrated zip cord was installed May 26, 1993.

Resolution status: Work packages are out to repair the manual tape and pump the catch tank. Extensive surface contamination in the surrounding area is hampering efforts to perform the needed activities. Sampling of the solution in the tank is necessary before pumping can begin. Completion of the transfer procedure is expected August 15, 1993. Estimated date of completion of pumping is September 1, 1993.

UX-302-A Catch Tank. Surface level measurement exceeds the maximum operating Timit of 50.00 inches. The level is 62.60 inches which exceeds the $50 \%$ volume of 54 inches ( 8840 gallons). The FIC plummet is contacting liquid.

Discrepancy report S\&DA-92-465 was issued May 12, 1992. A work package was initiated to pressure test lines and to pump liquid level to below alarm limits.

Resolution status: Work packages for the transfer of waste from UX-302-A and the repair of necessary instrumentation are being prepared, and the transfer of waste is being scheduled as a prestart item for the Cross Site Transfer. Completion of transfer procedure is expected August 15, 1993. A work package has been prepared to sample/pump this catch tank. Expected compietion date is September 1, 1993.

\section{SURVEILLANCE AND WASTE TANK STATUS HIGHLIGHTS}

\section{Tank 241-SY-101 Gas Venting}

The predicted gas release from Tank 241-SY-101 began on June 26, 1993. The initial surface level decrease was six inches, followed by smaller decreases over the next few days. At least a 7-inch drop in surface level is required before a window can be "opened," and on June 30, the tank level had decreased by 8 inches and Window "I" opening was approved for 30 days. On July 3, 1993, the 64-foot, 19,000-pound mixing pump was installed in sY-101. It is hoped to use the pump at the slowest effective speed to prevent hydrogen gas from building up to potentially explosive levels. The pump is expected to circulate liquid waste from the tank waste's upper layer and send it down toward the tank's bottom where two jet nozzles will discharge the fluid about two feet from the bottom. During the five days of Phase A testing, the pump was run for short periods each day. A gas release of $20 \mathrm{ppm}$ was recorded during the final test of Phase $A$ which was completed on July 20 . Phase B testing will last for one to two months and consists of 27 different pump runs. The pump will increase speed and will run between 20 minutes and four hours per day. In addition, the nozzles will be circulating from all directions during this second phase. Larger quantities of gas are expected to be released when the pump is run faster and longer. Figure 2, Tank 241-SY-101 Mixing Pump, shows the pump being installed. 
2. Four Tanks Removed from Ferrocyanide Watch List

On March 19, 1993, WHC requested approval from DOE-RL to remove six tanks (241-BX-102, BX-106, BX-110, and BX-111, BY-101 and T-101) from the ferrocyanide Watch List, on the basis that these tanks do not contain meaningful amounts of ferrocyanide sludge. This followed a study which concluded that these tanks contain $<1000$ gm moles of ferrocyanide. On July 9 , 1993, WHC was authorized to close the ferrocyanide Unreviewed Safety Question (USQ) associated with four tanks, 241-BX-110, BX-111, BY-101 and T-101, and remove them from the Watch List. The need for special monitoring of these tank temperatures is being reviewed. DOE-RL requested WHC to make an additional evaluation and a revised approval request for BX-102 and BX-106.

\section{Tank 241-SX-102 Removed from "Assumed Leaker" Status}

On July 20, 1993, WHC advised DOE-RL that 241-SX-102 had been reclassified from "Assumed Leaker" to "Sound," based on a review conducted by WHC and PNL using a new improved method for evaluating neutron scan data. See Unusual Occurrence Report RL-WHC-TFARM-1993-0044 below for further details.

\section{Potential New Watch List Tanks}

On May 24, 1993, WHC recommended to DOE-RL that Tank 241-U-111 be included on the organic tanks Watch List. This recommendation was based on information discovered during a review of historical records, which suggests that the total organic carbon (TOC) content of interstitial liquor in this tank is approximately 14 wt.\% (dry basis), which exceeds the 3 wt.\% (dry basis) of the organic Watch List criteria. Tank 241-U-107, currently on the organics Watch List, is being reviewed for also adding it to the hydrogen Watch List. Both tanks are undergoing USQ screening.

\section{Tank 241-C-105}

In accordance with Engineering Change Notice 196834, dated June 24, 1993, which changed the status of this tank from High Heat Load to Normal, Tank C-105 has been deleted from the High Heat Load table and added to the Low Heat Load table, effective July 1993. (See June Highlights, page 6, for complete information. See also next item below).

\section{Non-Watch List Low Heat Load Semiannual Temperatures}

Current WHC surveillance requirements call for temperatures to be taken in 97 low heat load tanks in January and July of each year. Temperature readings were obtained in 71 tanks in July 1993. There were no readings in 26 tanks; this includes nine tanks which are listed in the WHC-SD-RE-TI-053, Rev 7, "Riser Configuration for Single-Shell Waste Tanks," September 1991, as having no trees available. Table A-6, Non-WatchList Low Heat Load Tanks, has been added to this report. Tanks C-105, formerly on the High Heat Load list, and $B X-110, B X-111, B Y-101$, and T-101, formerly on the ferrocyanide Watch List, are included in Table $A-6$.

\section{Criticality Safety Issues}

On Apri1 30, 1992, an Unreviewed Safety Question (USQ) concerning criticality safety issues in the Tank Farms was declared to be a reportable event. Unusual Occurrence report RL-WHC-TANKFARM-1992-0037 was issued. A 
prohibition was placed on all waste transfers into and between the tank farm facilities which is negatively affecting various Hanford programs. On September 1, 1992, the approved Justification For Continued Operations (JCO) was received. This establishes the limitations for all tanks receiving transfers and also excludes any interim stabilization of single-shell tanks until further evaluations are completed and approved by DOE-HQ. On December 15, 1992, the approved JCO was issued as WHC-SD-WM-JCO-001, "Justification for Continued Operations of Hanford High Level Waste Tanks Resulting From the Criticality USQ, 492-CRITSAS." Resolution of the USQ is scheduled for summer 1993.

8. Occurrence Report

RL-WHC-TFARM-1993-0044 (UNUSUAL) - LIQUID OBSERVATION WELL (LOW) ON TANK 241-SX-102 INDICATES INTERSTITIAL LIOUID LEVEL DECREASE (Fina) Report)

On April 30, 1993, the quarterly Liquid Observation Well (LOW) reading taken in Tank 241-SX-102 indicated a decrease of 0.2 feet from the established baseline value. The reading was repeated on May 5, 1993, and this reading indicated a decrease of 0.3 feet which was equal to the established decrease criteria. Another reading taken on May 20, 1993, indicated an additional 0.1-foot decrease. This reading brought the total decrease to 0.4 foot, and exceeded the decrease criteria. On May 20, 1993, Tank 241-SX-102 was declared to be an "assumed leaker." Previous neutron LOW readings have been stable showing minor fluctuation between the baseline and 0.2 -foot decrease. Instrument repeatability is \pm 0.1 foot. The LOW is the primary means of liquid level detection because this tank has a solid surface.

This tank is actively ventilated with a waste temperature of approximately $150^{\circ} \mathrm{F}$. Although decreasing level trends attributed to evaporation have been recorded on other SX Tank Farm tanks (i. e., $S X-105)$, the $S X-102$ liquid level has decreased more rapidly than typicaliy observed. Tank $S X-102$ is a not yet interim-stabilized, Partial Isolated Watch List Tank (Hydrogen list), actively ventilated, with $183 \mathrm{Kgallon}$ drainable liquid.

Shortly after reporting this tank as an "assumed leaker," an improved method for evaluating the ILL from LOW data was developed by WHC and PNL. The new method improves on the accuracy and repeatability of the ILL measurements and reduces or eliminates some sources of variability which could previously lead to potentially misleading conclusions. Using the improved method the LOW data was re-evaluated, arriving at a different conclusion concerning the integrity status of this tank. After reviewing all available information, WHC concluded that there is no surveillance data which would indicate a loss of liquid attributed to a breach of integrity in this tank at this time, therefore, this tank meets the definition of a "sound tank." Tank 241-SX-102 was reclassified from "assumed leaker" to "sound," on July 20, 1993.

WHC intends to use the improved method for evaluating neutron scan data in LOWs for all applicable tanks starting on or before September 30, 1993. 


\section{WHC-EP-0182-64}

Changes to the Report:

1. Appendix A: Surveillance Monitoring Tables

Table A-6, Non-Watch List Low Heat Load Tanks ( $<40,000 \mathrm{Btu} / \mathrm{h})$ was added to this report. The temperatures in these tanks are taken semiannually, with exceptions as noted in the table. See item \#5 above for more details. Tank C-105 was added to this list because it was reclassified from High Heat Load to Normal and removed from the High Heat Load List effective July 1, 1993. Tanks $B X-110, B X-111, B Y-101$, and T-101 were removed from the ferrocyanide Watch List on July 9, 1993, and have been added to Table A-6 (see item \#2 above). 

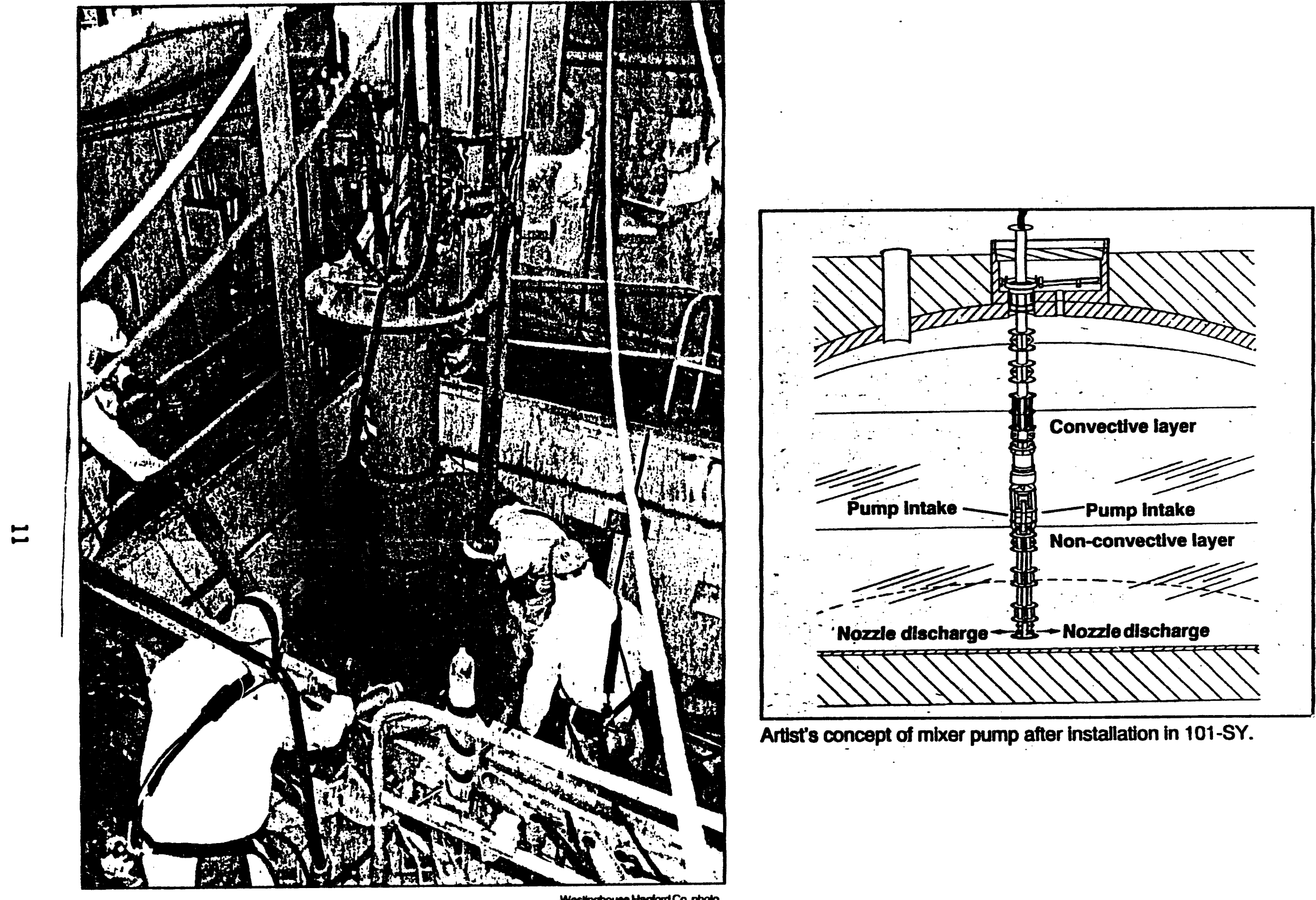

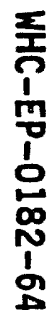

Hanlord workers install a giant circulation purnp in Tank 101-SY on Saturday afternoon.

Figure 2. Tank 101-SY Mixing Pump 
WHC-EP-0182-64

This page is intentionally left blank. 
WHC-EP-0182-64

\section{APPENDIX A}

\section{WASTE TANK SURVEILLANCE MONITORING TABLES}


WHC-EP-0182-64

This page intentionally left blank 


\section{TABLE A-1. WATCH LIST TANKS (Sheet 1 of 2)}

These tanks have been identifled as Watch List Tanks in accordance with Public Law 101-510, Section 3137, " Safety Measures for Waste Tanks at Hanford Nuclear Reservation." (1990). These tanks have been identified as the Priority 1 Haniord Site Tank Farm Safety Issues: "Issues/situations that contain most necessary conditions that could lead to worker (onsite) or ofisite radiation exposure through an uncontrolled release of fission products, e.g., Tank SY-101."

July 31, 1993

\begin{tabular}{|c|c|c|c|c|c|c|c|c|c|c|}
\hline \multicolumn{2}{|c|}{ Single-Shell Tanks } & \multirow{2}{*}{$\begin{array}{l}\text { Officially } \\
\text { Added to } \\
\text { Watch List }\end{array}$} & Single-S & hell $T$ & anks & $\begin{array}{l}\text { Officially } \\
\text { Added to }\end{array}$ & \multicolumn{3}{|c|}{ Single-Shell Tanks } & \multirow{2}{*}{$\begin{array}{l}\text { Officially } \\
\text { Added to } \\
\text { Watch List }\end{array}$} \\
\hline Tank No. & Category & & Tank No. & & Category & Watch List & Tank No. & & Category & \\
\hline $\begin{array}{ll}A-101 & (2) \\
A X-101 & (2) \\
A X-103 & (2) \\
\end{array}$ & $\begin{array}{l}\text { Hydrogen } \\
\text { Hydrogen } \\
\text { Hydrogen } \\
\end{array}$ & $\begin{array}{l}1 / 91 \\
1 / 91 \\
1 / 91 \\
\end{array}$ & $\begin{array}{l}S-102 \\
s-111\end{array}$ & $\begin{array}{l}\text { (2) } \\
\text { (2) } \\
\text { (2) }\end{array}$ & $\begin{array}{l}\text { Hydrogen, } \\
\text { Organic Salts } \\
\text { Hydrogen }\end{array}$ & $\begin{array}{l}1 / 91 \\
1 / 91 \\
1 / 91\end{array}$ & $\begin{array}{l}T Y-101 \\
T Y-103 \\
T Y-104 \\
\end{array}$ & $\begin{array}{l}(2) \\
(2) \\
(2) \\
\end{array}$ & $\begin{array}{l}\text { Ferrocyanide } \\
\text { Ferrocyanide } \\
\text { Ferrocyanide }\end{array}$ & $\begin{array}{l}1 / 91 \\
1 / 91 \\
1 / 91 \\
\end{array}$ \\
\hline $\mathrm{B}-103 \quad(2)$ & Organic Salts & $1 / 91$ & $s-112$ & (2) & Hydrogen & $1 / 91$ & $\overline{U-103}$ & (2) & Hydrogen & $1 / 91$ \\
\hline $\begin{array}{l}B X-102(2) \\
B X-106 \text { (2) }\end{array}$ & $\begin{array}{l}\text { Ferrocyanide } \\
\text { Ferrocyanide }\end{array}$ & $\begin{array}{l}1 / 91 \\
1 / 91\end{array}$ & $\begin{array}{l}S x-101 \\
S x-102\end{array}$ & $\begin{array}{l}\text { (1)(2) } \\
\text { (1)(2) }\end{array}$ & $\begin{array}{l}\text { Hydrogen } \\
\text { Hydrogen }\end{array}$ & $\begin{array}{l}1 / 91 \\
1 / 91\end{array}$ & $\begin{array}{l}U-105 \\
U-106\end{array}$ & $\begin{array}{l}\text { (2) } \\
\text { (2) }\end{array}$ & $\begin{array}{l}\text { Hydrogen } \\
\text { Organic Salts }\end{array}$ & $\begin{array}{l}1 / 91 \\
1 / 91\end{array}$ \\
\hline $\begin{array}{l}B Y-103(2) \\
\text { BY-104 (2) } \\
\text { BY-105 (2) }\end{array}$ & $\begin{array}{l}\text { Ferrocyanide } \\
\text { Ferrocyanide } \\
\text { Ferrocyanide }\end{array}$ & $\begin{array}{l}1 / 91 \\
1 / 91 \\
1 / 91\end{array}$ & $\begin{array}{l}s x-103 \\
s x-104 \\
s x-105\end{array}$ & $\begin{array}{l}\text { (1)(2) } \\
\text { (1)(2) } \\
\text { (1)(2) }\end{array}$ & $\begin{array}{l}\text { Hydrogen } \\
\text { Hydrogen } \\
\text { Hydrogen }\end{array}$ & $\begin{array}{l}1 / 91 \\
1 / 91 \\
1 / 91\end{array}$ & $\begin{array}{l}U-107 \\
U-108 \\
U-109\end{array}$ & $\begin{array}{l}\text { (2) } \\
(2) \\
(2)\end{array}$ & $\begin{array}{l}\text { Organic Salts } \\
\text { Hydrogen } \\
\text { Hydrogen }\end{array}$ & $\begin{array}{l}1 / 91 \\
1 / 91 \\
1 / 91\end{array}$ \\
\hline $\begin{array}{l}B Y-106 \text { (2) } \\
B Y-107 \text { (2) } \\
B Y-108 \text { (2) } \\
B Y-110 \text { (2) } \\
B Y-111 \text { (2) }\end{array}$ & $\begin{array}{l}\text { Ferrocyanide } \\
\text { Ferrocyanide } \\
\text { Ferrocyanide } \\
\text { Ferrocyanide } \\
\text { Ferrocyanide }\end{array}$ & $\begin{array}{l}1 / 91 \\
1 / 91 \\
1 / 91 \\
1 / 91 \\
1 / 91\end{array}$ & $\begin{array}{l}5 x-106 \\
5 x-109\end{array}$ & $\begin{array}{l}(1)(2) \\
(1)(2) \\
(1)(2)\end{array}$ & $\begin{array}{l}\text { Hydrogen, } \\
\text { Organic Salts } \\
\text { Hydrogen because } \\
\text { other tanks vent } \\
\text { thru it }\end{array}$ & $\begin{array}{l}1 / 91 \\
1 / 91\end{array}$ & $\frac{\text { Double-S }}{\text { Tank No. }}$ & $\| \mathrm{Ta}$ & & $\begin{array}{l}\text { Officially } \\
\text { Added to } \\
\text { Watch List }\end{array}$ \\
\hline $\begin{array}{ll}B Y-112 & (2) \\
C-103 & (2)(4) \\
C-106 & (2) \\
C-108 & (2) \\
C-109 & (2) \\
C-111 & (2) \\
C-112 & (2)\end{array}$ & $\begin{array}{l}\text { Ferrocyanide } \\
\text { Organic Salts } \\
\text { High Heat Load } \\
\text { Ferrocyanide } \\
\text { Ferrocyanide } \\
\text { Ferrocyanide } \\
\text { Ferrocyanide }\end{array}$ & $\begin{array}{l}1 / 91 \\
1 / 91 \\
1 / 91 \\
1 / 91 \\
1 / 91 \\
1 / 91 \\
1 / 91\end{array}$ & \begin{tabular}{|l|}
$T-107$ \\
$T-110$ \\
$T X-105$ \\
$T X-118$
\end{tabular} & $\begin{array}{l}\text { (3) } \\
\text { (2) } \\
\text { (2) } \\
\text { (2) } \\
\text { (2) }\end{array}$ & $\begin{array}{l}\text { Ferrocyanide } \\
\text { Hydrogen } \\
\text { Organic Salts } \\
\text { Ferrocyanide, } \\
\text { Organic Salts }\end{array}$ & $\begin{array}{l}2 / 91 \\
1 / 91 \\
1 / 91 \\
1 / 91 \\
1 / 91\end{array}$ & $\begin{array}{l}\text { AN-103 } \\
\text { AN-104 } \\
\text { AN-105 } \\
\text { AW-101 } \\
\text { SY-101 } \\
\text { SY-103 } \\
\text { OOnKS } \\
\end{array}$ & $\begin{array}{l}\text { (1)(2) } \\
\text { (1)(2) } \\
(1)(2) \\
(1)(5) \\
(1)(2) \\
(1)(2)\end{array}$ & $\begin{array}{l}\text { Hydrogen } \\
\text { Hydrogen } \\
\text { Hydrogen } \\
\text { Hydrogen } \\
\text { Hydrogen } \\
\text { Hydrogen } \\
\end{array}$ & $\begin{array}{l}1 / 91 \\
1 / 91 \\
1 / 91 \\
6 / 93 \\
1 / 91 \\
1 / 91 \\
\end{array}$ \\
\hline
\end{tabular}

See footnotes next page 


\section{TABLE A-1 WATCH LIST TANKS (Sheet 2 of 2)}

Footnotes:

(1) These eight single-shell ta ks and the six double-shell tanks on the Watch List are actively ventilated.

Although on various dates WHC identified tanks which contained ferrocyanide, organic salts, etc., which were then added to this report as Watch List tanks, the following official notifications were made to DOE-RL:

(2) Letter 9059124, H. D. Harmon, WHC, to R. E. Gerton, DOE-RL, "Safety Measures for Waste Tanks at Hanford Site, Richland, Washington," dated January 8, 1991, identified 23 ferrocyanide tanks, 23 tanks with potential for accumulation of flammable gas, eight organic tanks, and one high heat load tank, as being Watch List tanks. (52 tanks)

The ferrocyanide and hydrogen tanks were declared Unresolved Safety Questions (USQ); the organic tanks and the high heat load tank were within the safety envelope as defined by the safety analysis reports and were not designated as USQs.

(3) Letter 9059124.1 (revision to 9059124 above), dated February 8, 1991, added T-107 to the Ferrocyanide Watch List. (53 tanks)

(4) Tank C-103 was declared a USQ per Unusual Occurrence Report RL-WHC-TANKFARM-1992-0069, issued September 1992, because of an organic layer covering the surface. This tank was previously identified as a Watch List tank in footnote (2) above.

(5) Letter 9354700, J. C. Fulton, WHC, to R. E. Gerton, DOE-RL, "Addition of Tank 241-AW-101 to Flammable Gas Watch List," dated June 3, 1993, added this double-shell tank to the Watch List. (54 tanks)

Notes: $\mathrm{BX}-110, \mathrm{BX}-111, \mathrm{BY}-101$ and T-101 were removed from the Ferrocyanide Watch List in July 1993, per letter 93-CAB-223, John H. Anttonen, DOE-RL, to T. M. Anderson, WHC, "Resolution of Unreviewed Safety Question for Four Ferrocyanide Tanks," dated July 9, 1993.

Letter 9353957, J. C. Fulton, WHC, to R. E. Gerton, DOE-RL, "Single-Shell Waste Tank 241-U-111," dated May 24, 1993, recommended this tank be included on the Organic Tanks Watch List. This recommendation has not yet been accepted by DOE-RL. 
TABLE A-2. TANKS CONTAINING >1000 GRAM MOLE OF FERROCYANIDE (Watch List Tanks) (Sheet 1 of 2)

These tanks have been declared an Unreviewed Salety Question (USO) because their explosion potential exceeds previously reported safety analysis consequences (1). Tanks containing ferrocyanide are required to be monitored for temperatures at least weekly.

Temperatures in these tanks did not exceed the maximum temperature criteria or surveillance frequency limits for July 1993. All Watch List tanks are reviewed for increasing temperature trends. Tanks connected to TMACS are required to be monitored continuously: the others are required to be monitored weekly. Temperatures are taken in the waste unless indicated otherwise.

\begin{tabular}{|c|c|c|c|c|c|c|c|c|c|c|}
\hline Tank No. & & $\begin{array}{c}\text { Highest } \\
\text { Temperature } \\
\text { Peading } \\
\text { in Waste (F.) }\end{array}$ & $\begin{array}{c}\text { Date } \\
\text { of } \\
\text { Reading } \\
\end{array}$ & $\begin{array}{c}\text { Monitored } \\
\text { by } \\
\text { TMACS (5) }\end{array}$ & $\begin{array}{c}\text { Total } \\
\text { Waste } \\
\text { (inches) (6) }\end{array}$ & $\begin{array}{c}\text { FeCN (2) } \\
(\times 1000 \mathrm{~g} \mathrm{~mol})\end{array}$ & $\frac{\text { Estimated }}{(\text { Btu/h) }}$ & 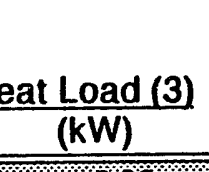 & $\begin{array}{c}\text { Date } \\
\text { Declared } \\
\text { Assumed } \\
\text { Leaker } \\
\end{array}$ & $\begin{array}{c}\text { Interim } \\
\text { Stabilized } \\
\text { Date } \\
\end{array}$ \\
\hline B) $10 \%$ & & $\overline{1}$ & 0708193 & (No 10. & 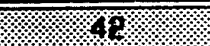 & ( & 410000 & 2993 & $19711=$ & 1078 \\
\hline$B X-106$ & & 64 & $07 / 16 / 93$ & No & 24 & $<1$ & $<10000$ & $<2.93$ & Sound & N/A \\
\hline 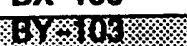 & & 86 & 07126193 & Yos. & 1538 & $66 \%$ & 86000 & 2852 & 19978 & WNA \\
\hline$B Y-104$ & Riser 1 & 127 & $07 / 16 / 93$ & Yes & 155 & 83 & 5500 & 1.61 & Sound & $1 / 85$ \\
\hline $8 x$ & DIsor 108 & 15 & 071729 & Yos. & $155 \%$ & $69 \%$ & 58601 & 681: & souno: & $1185 \%$ \\
\hline$B Y-105$ & Riser 10C & 194 & $07 / 12293$ & Yes & 190 & 36 & 3400 & 0.97 & 1984 & N/A \\
\hline $89 x$ & Ms6r & 2 & 07118493. & ros. & $190 \%$ & 86 & 400 & 997\% & $198 \%$ & NIA \\
\hline$B Y-106$ & & 129 & $07 / 26 / 93$ & Yes & 241 & 70 & 3300 & 0.97 & 1984 & N/A \\
\hline Bux 607 & & $95 \%$ & 0726193 & ros. & $10 \%$ & $48 \%$ & 14500 & $425:$ & 1989 & 7779. \\
\hline$B Y-108$ & & 108 & $07 / 26 / 93$ & Yes & 90 & 58 & 23000 & 6.74 & 1972 & $2 / 85$ \\
\hline $87 \% \times 10$ & qus & Kao & 0731193 & $10 \%$ & 152. & \% & $25200 \%$ & $7 \times 99:$ & Sound & 1185. \\
\hline$B Y-110$ & Riser io & 108 & $07 / 31 / 93$ & No & 152 & 71 & 25200 & 7.39 & Sound & $1 / 85$ \\
\hline BY & SOH: & 67 & 0726193 & $\mathrm{Y}=\mathrm{s}$ & 874 & 6 & 84200 & 1002. & $5000 \%$ & 1785 . \\
\hline BY-111 & Riser 14 & 84 & $07 / 29 / 93$ & Yes & 174 & 6 & 34200 & 10.02 & Sound & $1 / 85$ \\
\hline GY\%rts: & How: & 83 & 07126193: & $\gamma \times \mathbf{s}$ & $418 \%$ & 2 & 410000 & \%293\% & Sound\% & $5 / 85 \%$ \\
\hline$B Y-112$ & Riser 5 & 89 & $07 / 26 / 93$ & Yes & 113 & 2 & $<10000$ & $<2.93$ & Sound & $5 / 85$ \\
\hline 6108 & & 28 & 07129193 & 110. & 31 & 5 & 10000 & \% 93 & Souno & $3 / 84$. \\
\hline$C-109$ & Riser 1 & 76 & $07 / 08 / 93$ & No & 31 & 30 & 3800 & 1.11 & Sound & $11 / 83$ \\
\hline (8) 109 & pisor 8 & 66 & 07124 93 & No: & 311 & 20 & 18300 & 1111 & Sound: & $11183 \%$ \\
\hline C-111. & & 74 & $07 / 16 / 93$ & No & 28 & 33 & $<10000$ & $<2.93$ & 1968 & $3 / 84$ \\
\hline g. & 8R & $78:$ & 07129193. & No. & $45 \%$ & $31 \%$ & $1000 \%$ & $293 \%$ & souno & 9990 . \\
\hline C-112 & Riser 8 & 80 & $07 / 29 / 93$ & No & 45 & 31 & $<10000$ & $<2.93$ & Sound & $9 / 90$ \\
\hline$T-107$ & & 64 & $07 / 29 / 93$ & No & 73 & 5 & $<10000$ & $<2.93$ & 1984 & N/A \\
\hline$T X-118(4)$ & & 76 & $07 / 29 / 93$ & Yes & 134 & $<1$ & 4900 & 1.44 & Sound & $4 / 83$ \\
\hline$T \gamma-101$ & & 64 & $07 / 26 / 93$ & Yes & 50 & 23 & $<10000$ & $<2.93$ & 1973 & $8 / 83$ \\
\hline TY 103 & & 699 & 07112493 & Yos & $66 \%$ & 28 & $\$ 100010$ & $1293 \%$ & $197 / 3$. & 2183 \\
\hline$T Y-104$ & & 64 & $07 / 26 / 93$ & Yes & 24 & 12 & $<10000$ & $<2.93$ & 1981 & $1 / 83$ \\
\hline 2001aks & & & Legend: & WACS & Moniloring & Ooniros System & & & & \\
\hline
\end{tabular}

Note: Tanks BX-110, BX-111, BY-101 and T-101 were removed from this Watch List in July 1993, per letter 93-CAB-223, John H. Anttonen, DOE-RL, to T. M. Anderson, WHC, "Resolution of Unreviewed Safety Question for Four Ferrocyanide Tanks," dated July 9, 1993.

FOOTNOTES: See next page 


\section{TABLE A-2. TANKS CONTAINING >1000 GRAM MOLE OF FERROCYANIDE (Watch List Tanks) (Sheet 2 of 2)}

\section{FOOTNOTES:}

(1) This Priority 1 Waste Tank Safety Issue is stated as follows: "Could the concentrations and distribution of ferrocyanide and nitrate/nitrite in the tanks lead to an explosion if allowed to heat up or if an uncontrolled exothermic reaction could occur?"

(2) The amount of FeCN reported in the tanks is based on WHC-SD-WM-ER-133-REV 0, "An Assessment of the Inventories of the FeCN Watch List Tanks," (Table 3-7), October 1991.

(3) The estimated heat generation rates are from WHC-EP-0474-4, "Quarterly Report on Defense Nuclear Facilities Safety Board Recommendation 90-7 for the Period Ending March 31, 1992," Table 1-A, dated January 1992. Tank 104-BY only estimated per WHC-EP-0521, "SST 104-BY Thermal Hydraulic Analysis," October 1991 (kW =3412 Btu/h). A new thermal hydraulic analysis of several tanks is currently being updated and is expected to be processed for external release by the end of FY1993. This document analyzes six tanks, BY-105, 106, 108, 110, and 111, and C-109. Information from this document will be incorporated in future monthly reports as soon as the clearance process is completed.

(4) This tank also contains a high concentration (>3\% wt TOC) of organic salts.

o (5) This column indicates which tanks are being monitored by the Tank Monitoring \& Control System (TMACS); automatic temperature readings are taken continuously. Temperatures in tanks connected to TMACS but temporarily not being monitored by TMACS are taken manually. Temperatures in BY-110 are currently being taken manually.

(6) Total waste in Kgal taken from Table E-5, Inventory and Status by Tanks for SSTs. Kgal/inches calculations for the temperature tables are as follows:

$$
\frac{\text { Kgal waste }-12.5 \mathrm{Kgal} \text { waste }}{2.75 \mathrm{Kgal} / \mathrm{inch}}+12 \text { inches }^{*}
$$

- The bottom 12 inches in dish bottom tanks contain $12.5 \mathrm{Kgal}$. All tanks are calculated as dish bottom tanks for the temperature tables, although A and AX farms have flat bottoms. Inches are from centerline tank bottom. 


\section{TABLE A-3. TANKS WITH POTENTIAL FOR HYDROGEN OR FLAMMABLE GAS ACCUMULATION ABOVE THE FLAMMABILITY LIMIT (Watch List Tanks)}

These tanks have been declared an Unreviewed Safety Question (USQ) because of the potentlal consequences of a radiological release resulting from a flammable gas burn, an event not analyzed in previous safety analyses.

Temperatures in these tanks did not exceed the applicable maximum temperature criteria or surveillance frequency limits for the month of July 1993. All Watch List tanks are reviewed for increasing temperature trends. Temperatures are taken in the waste unless indicated otherwise.

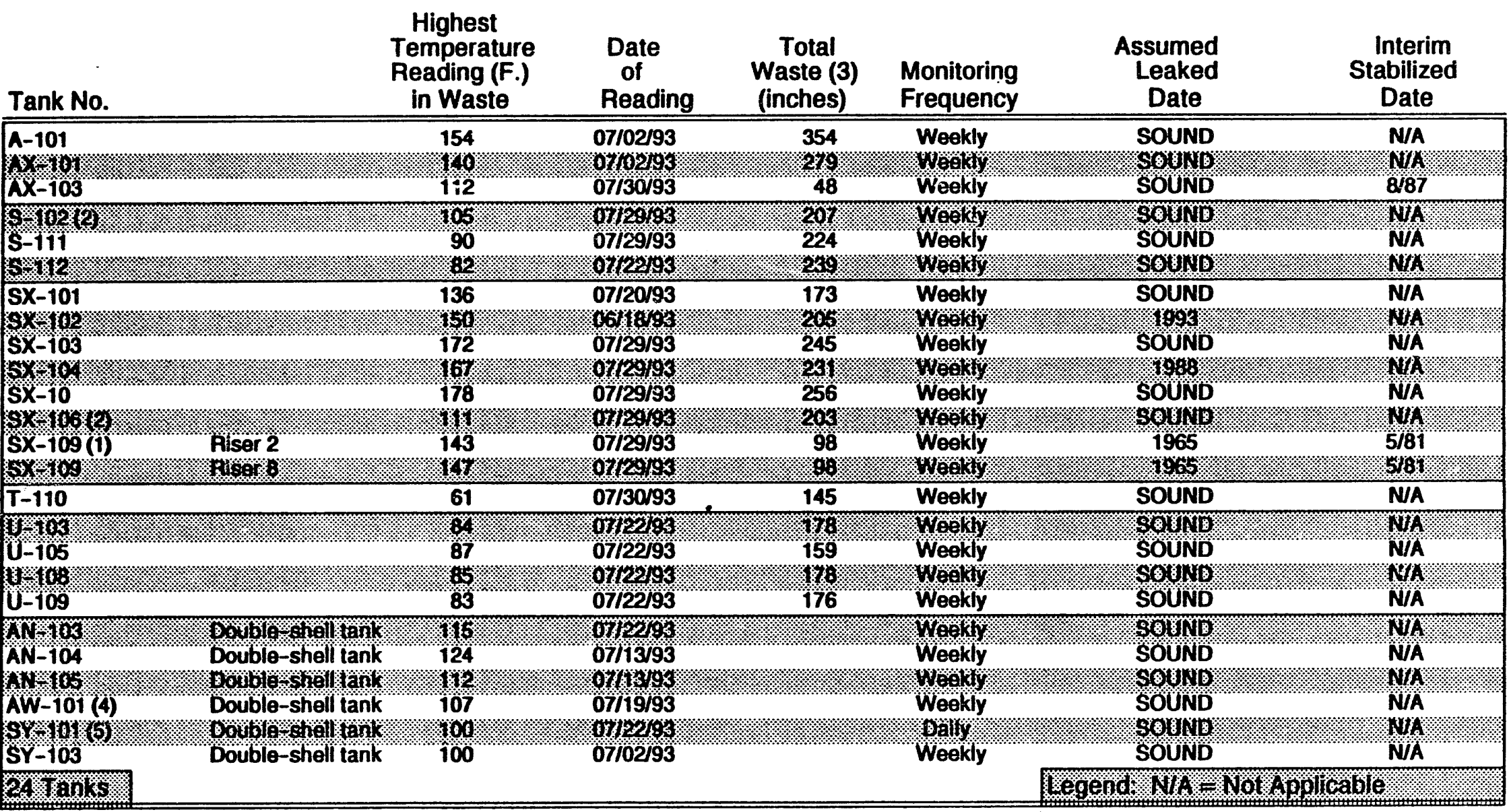

(1) Tank SX-109 has the potential for flammable aas accumulation only because other SX tanks vent through it

(2) Tanks S-102 and SX-106 also contain potentially high concentrations of organic salts

(3) See footnote (6) in Table A-2 (Ferrocyanide Tanks) for Total Waste/nnches calculations

(4) Tank 241-AW-101 was added to this list per letter 9354700, J. C. Fulton, WHC, To R. E. Gerton, DOE-RL, "Addition of Tank 241-AW-101 to Flammable Gas Watch List," dated June 3, 1993.

(5) Temperature dropped after gas release which occurred on 6/26/93. 


\section{TABLE A-4. SINGLE-SHELL TANKS CONTAINING CONCENTRATIONS OF ORGANIC SALTS $>3$ WEIGHT \% TOC (Watch List Tanks)}

These tanks have organic chemicals which are potentlally flammable and mixtures of organic materials mixed with nitrate and nitrate salts can defiagrate. They are listed here because of thelr "polential for release of high level waste because of uncontrolled increases in the temperature or pressure." Double-Shell tanks having $>3$ Weight \% TOC are not on the Watch List because they contain mostly liquld and there is no credible organic safety concern for tanks which contain mostly liquid. The safety concern is with tanks that primarlly contain solids because they could dry out and heat up, and "high organic concentrations in the tanks could support an exothermic reaction at elevated temperatures (350 degrees F/180 degrees C)." These tanks (with the exception of C-103), do not have an assoclated USQ because the presence of organic materlal was reviewed in the SST Safety Analysis Report.

Temperatures in these tanks did not exceed the applicable maximum temperature criteria or surveillance frequency limits for the month of July 1993. These tanks are monitored weekly. All Watch List tanks are reviewed for increasing temperature trends.

Temperatures are taken in the waste unless indicated otherwise.

\begin{tabular}{|c|c|c|c|c|c|}
\hline Tank No. & $\begin{array}{c}\text { Temperature } \\
\text { Reading (F.) } \\
\text { in Waste }\end{array}$ & $\begin{array}{c}\text { Date } \\
\text { of } \\
\text { Reading }\end{array}$ & $\begin{array}{l}\text { Total } \\
\text { Waste } \\
\text { Inches (4) }\end{array}$ & $\begin{array}{l}\text { Assumed } \\
\text { Leaked } \\
\text { Date }\end{array}$ & $\begin{array}{c}\text { Interim } \\
\text { Stabilized } \\
\text { Date }\end{array}$ \\
\hline B-103 & 61 & $07 / 08 / 93$ & 29 & 1978 & $2 / 85$ \\
\hline $6=105 / 51$ & 10 & 0729198 & 18 & SOUNB. & $\%$ \\
\hline$s-102(1)$ & 105 & $07 / 29 / 93$ & 207 & SOUND & N/A \\
\hline 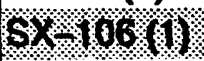 & 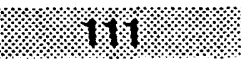 & 01729195 & 203. & SOUNB & $W /$. \\
\hline $\mathrm{TX}-105$ & 96 & $07 / 29 / 93$ & 228 & 1977 & $9 / 83$ \\
\hline $18=180$ & 768 & 10729193 & 134. & SOHAB & 1188 \\
\hline$U-106$ & 78 & $07122 / 93$ & 90 & SOUND & NIA \\
\hline $1310 \%$ \% & 15. & $172019 \%$ & 155 & SOHNB & WIA \\
\hline $818 n_{k}$ & & & & & \\
\hline
\end{tabular}

(1) These tanks also have the potential for hydrogen or flammable gas accumulation

(2) Tank TX-118 also contains ferrocyanide

(3) Tank C-103 was declared a USQ per Unusual Occurrence Report RL-WHC-TANKFARM-1992-0069, issued September 1992, because of an organic layer covering the surface.

(4) See lootnote (6) in Table A-2 (Ferrocyanide Tanks) for Total Waste/lnches calculations 


\section{TABLE A-5. SINGLE-SHELL TANKS WITH HIGH HEAT LOADS $(>40,000$ Btu/h)(Sheet 1 of 2)}

High heai load tanks have temperature survelliance requirements established by SD-WM-SAR-006 REV 1, "SST Isolation Salety Analysis Report," dated Januaiy 1986, and OSD-T-151-00013 REV D-O, "Operating Specifications for Single-Shell Waste Storage Tanks," dated August 1990. While all of these tanks are considered high heat load tanks per SAR definition, only one (241-C-106) is on the High Heat Watch List.

Temperatures in these tanks did not exceed SAR or OSD requirement limits for the month of July 1993. All high heat load tanks are on active ventilation. These high heat tanks are reviewed for increasing temperature trends.

Temperatures are taken in the waste unless indicated otherwise.

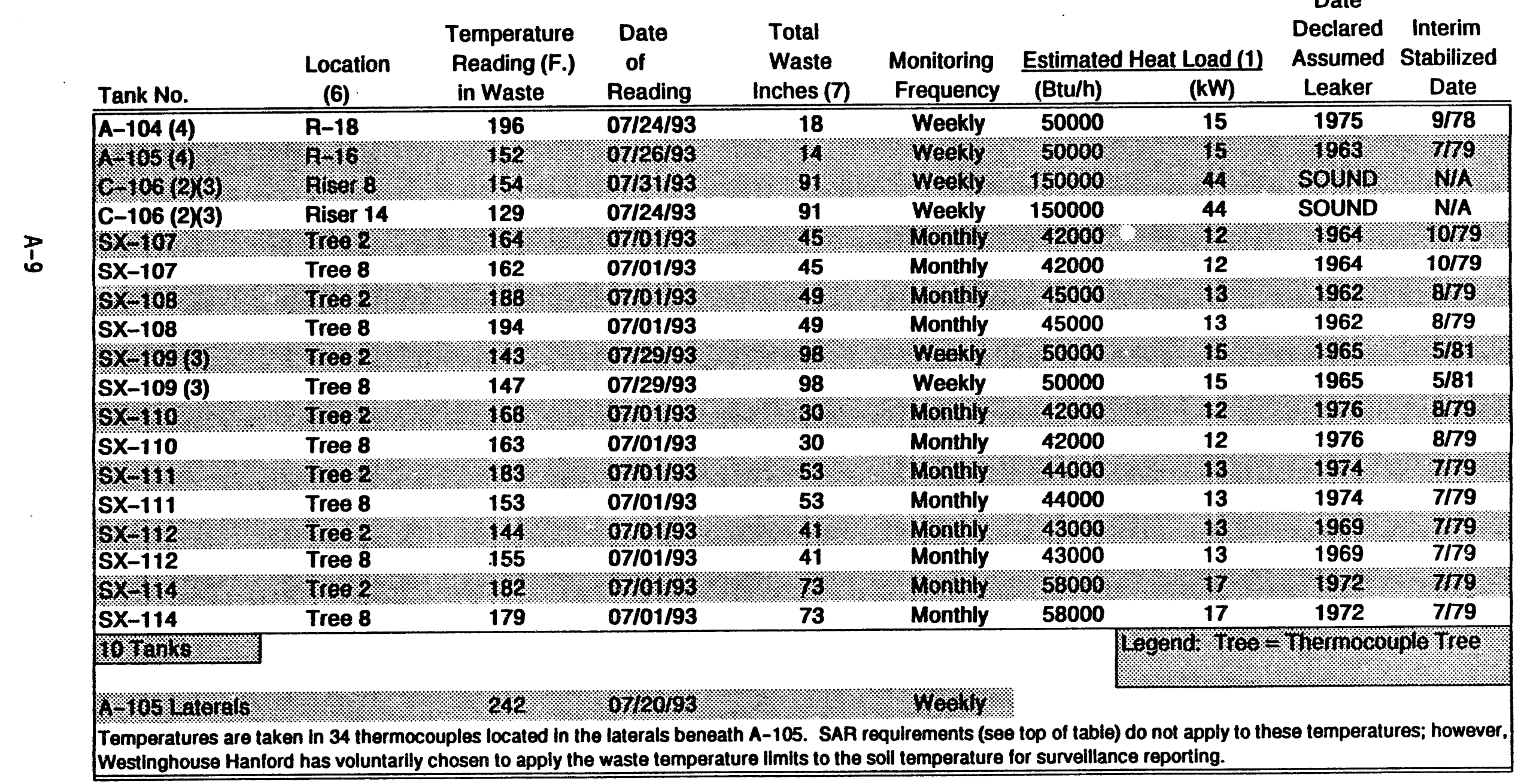




\section{TABLE A-5. SINGLE-SHELL TANKS WITH HIGH HEAT LOADS $(\mathbf{4 0 , 0 0 0}$ Btu/h)(Sheet 2 of 2)}

\section{Footnotes:}

(1) High heat loads as of 1988, evaluation completed April 20, 1989 (kW = 3412 Btu/h). The predominant heat load for these tanks is from CS 137 (half Ilfe of 30 years) and SR 90 (half IIte of 28.1 years). Tank C-105 was re-evaluated In WHC-SD-WM-ER-178, "Thermal Analysis of Tank 241-C-105 in Support of Process Test," January 1993. Engineering Change Notice \$196834, June 24, 1993, changed the status of C-105 from High Heat Load to Normal, effective July 1. 1993.

(2) Perlodic water additions are required in C-106 to maintaln evaporative cooling and thus prevent overheating. This tank Is scheduled for partial retrieval starting in 1997, at which time cooling water additions will be disconilinued.

(3) Watch List Tanks: C-106 is on the Watch List because "without water additions (in the event of a leak) the tank could exceed structural temperature limits resulting in unacceptable structural damage." SX-109 is on the hydrogen Watch List because it has the potential for flammable gas accumulation due to other $\mathbf{S X}$ tanks venting through li.

(4) A-104/105/106 exhauster has been out of service from October 1, 1991, untll August 20, 1992, when It was briefly restarted. Problems exist which must be resolved before the exhauster is operatlonal. Temperatures in A-104 and A-105 are monitored weekly.

(5) Maximum lateral temperatures under A-105 Increased 20 degrees F. by January 1992, but then dropped a few degrees and have remalned fairly stable at current temperature. These temperatures are monitored weekly.

(6) Tanks $A-104$ and $A-105$

Two temperature probes are Installed in risers in A-104, and six are Installed in risers in A-105. These are individual probes. In A-104, the probes are in contact with the sludge; In A-105, they are in contact with the bottom of the tank (A-105 has a bulged bottom).

Tank C-106

Tank C-106 has six functioning thermocouples ("il through 6).

Tanks SX-107, 108, 109, 110,111, 112, and 114

Each of these tanks has elght thermocouple trees, with elght thermocouples on each tree, with the exception of SX-108, which has four operational thermomocouples on each of two trees. Tree $* 2$ and Tree $\$ 8$ are monitored in each of these SX tanks.

(8) Calculations for Total Waste Inches: see footnote (6), Table A-2 (Ferrocyanide Tanks)

(9) There are 19 single-shell tanks with active ventllation (elght are on the Watch List as Indicated by an asterisk):

$\begin{array}{lll}A-104 & S X-101: & S X-107 \\ A-105 & S X-102: & S X-108 \\ A-106 & S X-103: & S X-109 \\ C-104 & S X-104: & S X-110 \\ C-105 & S X-105: & S X-111 \\ C-106 & S X-106 & S X-112 \\ & & S X-114\end{array}$


TABLE A-6. NON-WATCH LIST LOW HEAT LOAD TANKS $(<40,000 \mathrm{Btu} / \mathrm{h})$ (Page 1 of 3 )

Temperatures are taken semiannually in January and July, unless otherwise indicated, in the following 97 single-shell tanks. Legend follows table.

\section{Highest Temperatures}

taken in waste Total Waste (1)

Tank No. Jan. 93 Jul.93 Kgal Inches

\section{Comments}

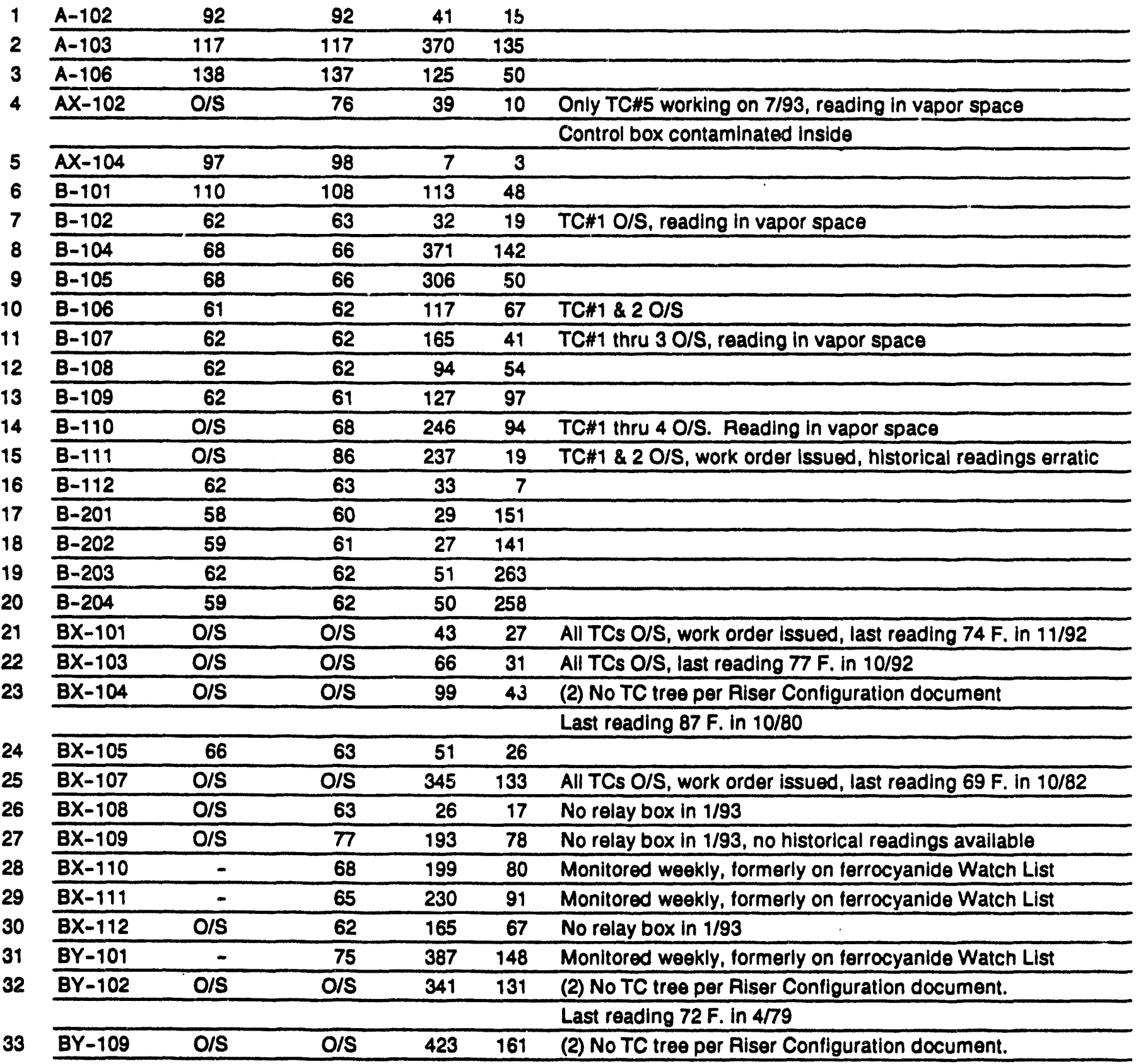




\title{
TABLE A-6. NON-WATCH LIST LOW HEAT LOAD TANKS (<40,000 Btu/h)
}

\author{
(Page 2 of 3)
}

Temperatures are taken semiannually in January and July, unless otherwise indicated, in the following 97 single-shell tanks. Legend follows table.

\section{Highest Temperatures}

taken in waste Total Waste (1)

Tank No. Jan. 93 Jul. 93 Kgal Inches

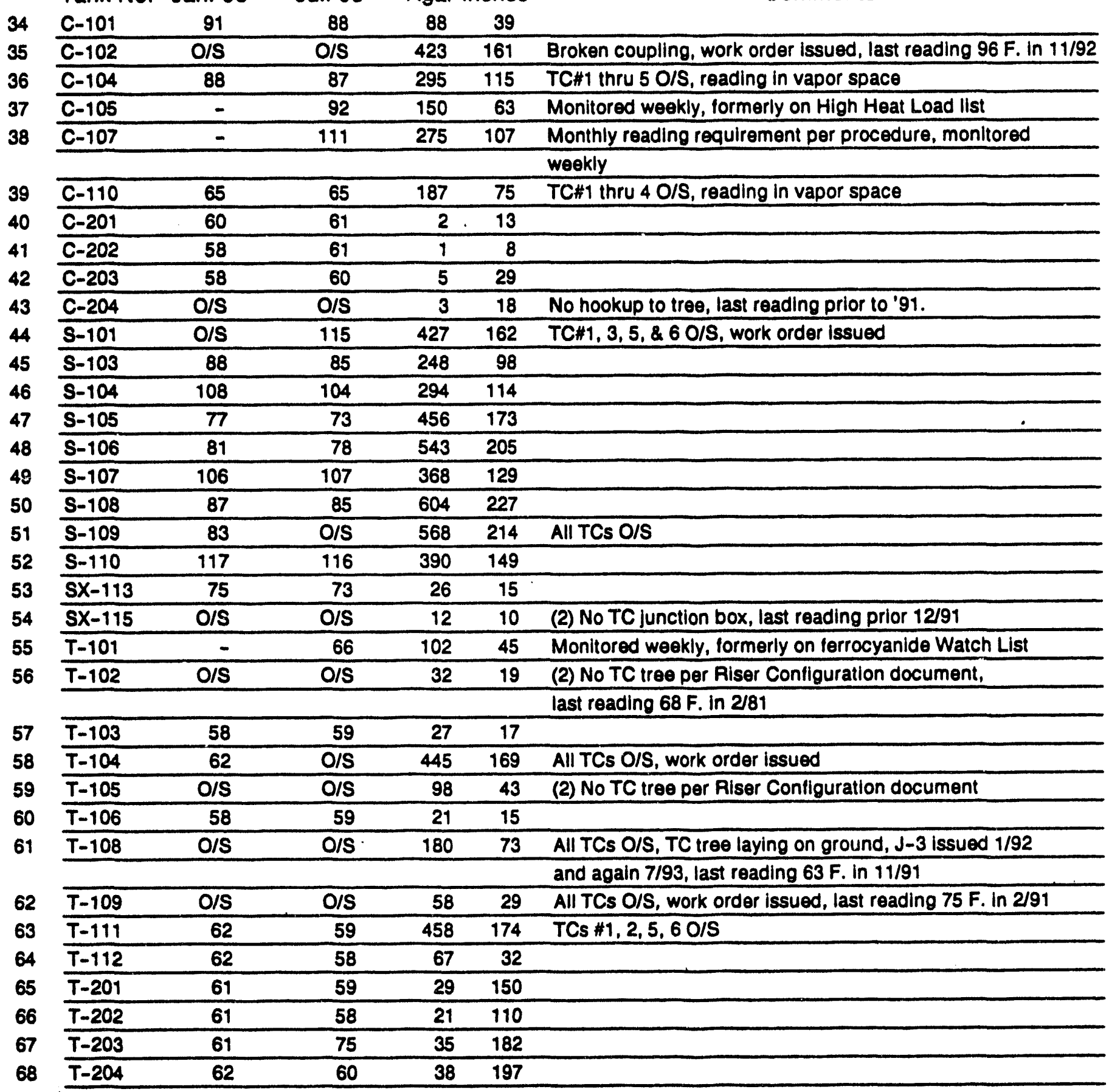




\section{TABLE A-6. NON-WATCH LIST LOW HEAT LOAD TANKS $(<40,000 \mathrm{Btu} / \mathrm{h})$ (Page 3 of 3)}

Temperatures are taken semiannually in January and July, unless otherwise indicated, in the following 97 single-shell tanks. Legend follows table.

Highest Temperatures taken in waste Total Waste (1)

Tank No. Jan. 93 Jul. 93 Kgal Inches Comments

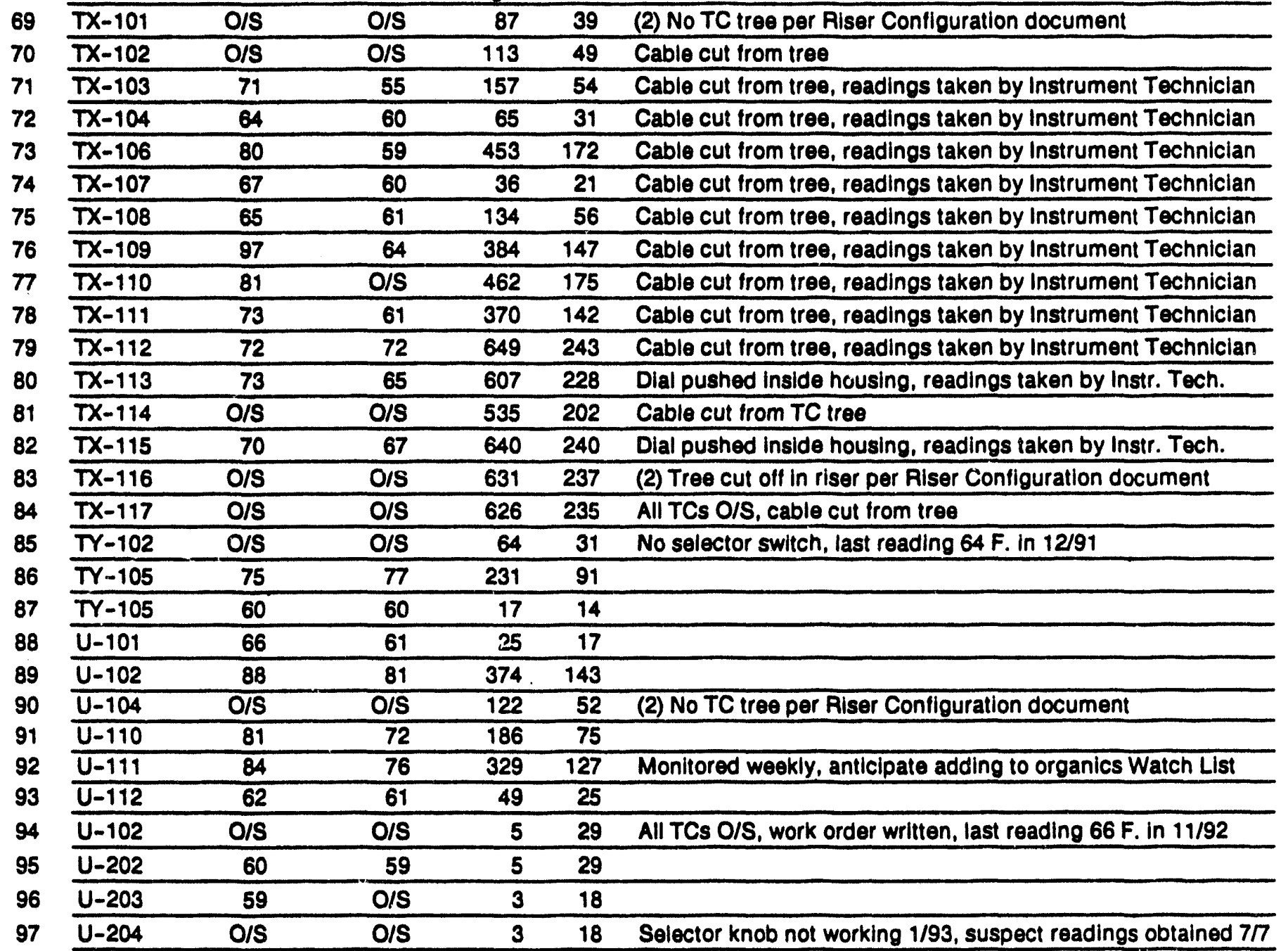

(1) See Table A-2 (footnote 6) for waste gallons/inches calculations.

(2) Thermocouples in nine tanks (BX-104, BY-102, BY-109, SX-115, T-102, T-105, TX-101, TX-116, and U-104) are out of service due to no TC trees in these tanks, or the thermocouples have been cut off, covered over, or are otherwise unable to function, per the Riser Configuration document. (Also see comment section above)

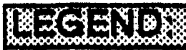

TC - Thermocouple

O/S - Out of senvice

Riser Conflguration document - WHC-SD-RE-TI-053, REV 8, "Riser Configuration Document for Single-Shell Tanks," September 1991

- Readings obtained in July 1993 Tanks

No readings (TC trees O/S - includes nine tanks with no trees - 800 footnote above) Total low heat load tanks 


\section{TABLE A-7. SINGLE-SHELL TANKS MONITORING COMPLIANCE STATUS 149 TANKS (Sheet 1 of 5)}

The following table indicates whether Single-Shell tank monitoring was in compliance with the requirements as specified in the applicable documents as of the last day of the applicable month:

NOTE:

All Watch List and High Heat tank temperature monitoring is in compliance. (5)

All Dome Elevation Survey monitoring is in compliance.

All Drywell monitoring is in compllance.

Psychrometrics (2)

In-tank Photographs (3)

Pressure Monitoring (6)

CAM/RAMP Monitoring (7)

Vapor Monitoring (8)

\begin{tabular}{|c|c|}
\hline LEGEND: & - In complianoe with all applicable dooumentation \\
\hline O/C & = Out of compliance with documentation \\
\hline-357 & $\begin{array}{l}=\text { WHC-SD-WM-TI-357, "Wacte Storage Tank Status and Lauk } \\
\text { Dotection Criteria" }\end{array}$ \\
\hline POP & $\begin{array}{l}\text { - Plant Operating Procedure TO-040-650, "Obtain/Record SST } \\
\text { Temperatureo" }\end{array}$ \\
\hline M.T. & = Manual Tape \\
\hline FIC & - Food Inetrument Company \\
\hline OSAVAR & $\begin{array}{l}\text { - Operatione Safoty Requiremente/Saloty Analydie Report, } \\
\text { SD-WM-SAR-006, Rev 2, 2/80; -SAR-034, Rev 0, Q181 }\end{array}$ \\
\hline $\mathbf{0 S 0}$ & - Operating Specification, Doc., OSD-T-151-00013, Rev D-O, 8sso \\
\hline N/A & - Not Applicable (i.e., no LOW, M.T, FIC inctalled) \\
\hline O/S & - Out of Senvice \\
\hline $\begin{array}{l}\text { Gamma } \\
\text { Noutron }\end{array}$ & $\begin{array}{l}\text { - LOW readinge taken by Gamma probe } \\
\text { - LOW readinge taken by Neutron probe }\end{array}$ \\
\hline
\end{tabular}

Information as of 7/31/93

\begin{tabular}{|c|c|c|c|c|c|c|c|c|c|c|}
\hline \multirow{4}{*}{$\begin{array}{l}\text { Tank } \\
\text { Number }\end{array}$} & \multirow{2}{*}{\multicolumn{2}{|c|}{ Category }} & \multirow{4}{*}{$\begin{array}{c}\text { Temperature } \\
\text { Readings } \\
\text { (5)(6) } \\
\end{array}$} & \multirow{3}{*}{\multicolumn{2}{|c|}{$\begin{array}{c}\text { Surface Level } \\
\text { Readings (1) } \\
\text { (-357) }\end{array}$}} & \multirow{3}{*}{\multicolumn{2}{|c|}{$\begin{array}{l}\text { LOW Readings } \\
(-357)\end{array}$}} & \multicolumn{2}{|c|}{ Radiation Readings } & \multirow{4}{*}{$\begin{array}{c}\text { Dome } \\
\text { Elevation } \\
\text { Surveys } \\
\text { (OSR/SAR) }\end{array}$} \\
\hline & & & & & & & & \multirow{3}{*}{$\begin{array}{c}\text { Lateral } \\
\text { Readings } \\
(-357) \\
\end{array}$} & \multirow{3}{*}{$\begin{array}{c}\text { Drywell } \\
\text { Readings } \\
\text { (OSRVSAR) } \\
\end{array}$} & \\
\hline & \multirow{2}{*}{$\begin{array}{l}\text { Watch } \\
\text { List(6) }\end{array}$} & \multirow{2}{*}{$\begin{array}{l}\text { High } \\
\text { Heat } \\
\end{array}$} & & & & & & & & \\
\hline & & & & M.T. & FIC & Gamma & Noutron & & & \\
\hline$A-101$ & $x$ & & & & $10 \%$ & & & ONC & & \\
\hline$A-102$ & & & & W' & & W1 & 118 & $O K$ & & \\
\hline$A-103$ & & & & NT. & & & & OK & & \\
\hline$A-104$ & & $\bar{x}$ & & & U4: & WA & WA & & & \\
\hline$A-105$ & & $\bar{x}$ & & & 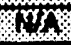 & NII & KW & & & \\
\hline$A-100$ & & & & rist & & U1 & \%rs & & & \\
\hline AX-101 & $\bar{x}$ & & & WH & & & & & & \\
\hline$\alpha x-102$ & & & & O/C & WW & NA & NA & & & \\
\hline Ax-103 & $x$ & & & 9ras: & & $\mathrm{x}$ & m & & & \\
\hline$A x-104$ & & & & & an & MI & III & & & \\
\hline$B-101$ & & & & 4 & & WW & WH & & & \\
\hline$B-102$ & & & & $\mathrm{WA}$ & & Wh & WM & & & \\
\hline$B-103$ & $\bar{X}$ & & & na & & y. & v1t & & & \\
\hline 8-104 & & & & & साA & & & & & \\
\hline$B-105$ & & & & & $\mathrm{NIT}$ & & & & & \\
\hline B-106 & & & & wh & & WA & 19 & & & \\
\hline B-107 & & & & & 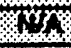 & WIX & $\mathrm{xr}$ & & & \\
\hline$B-108$ & & & & Ths & & $\mathrm{NH}$ & NIS & & & \\
\hline $8-100$ & & & & & W & $\mathrm{WH}$ & 4 & & & \\
\hline$B-110$ & & & & $\mathrm{OKC}$ & 6x & $\mathrm{ax}$ & $\mathrm{WH}$ & & & \\
\hline B-111 & & & & YWX & & wh & Ho & & & \\
\hline B-112 & & & & Wrs & & 13 & 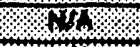 & & & \\
\hline$B-201$ & & & & & Wx & WN & 14 & 2 & & \\
\hline B-202 & & & & & Wh & $\mathrm{WN}$ & 11 & & & \\
\hline$B-203$ & & & & & 14 & $\mathrm{x}$ & $1 \times$ & & & \\
\hline $8-204$ & & & & & NH & rirs & N4 & & 1 & \\
\hline EX-101 & & & OLC & & $x$ & rts & 4 & & & \\
\hline $8 x-102$ & $x$ & & & & 84 & Wh & ras & & & \\
\hline $8 x-103$ & & & OKC & $2 \times$ & & 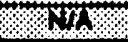 & 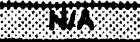 & & & \\
\hline$B x-104$ & & & DE-OK & 924 & & Mrs & Mrs & & & \\
\hline $8 x-105$ & & & & $1 \%$ & & 14 & 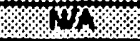 & & & \\
\hline$B X-108$ & $x$ & & & Q11 & & Wh & NA & & & \\
\hline$B X-107$ & & & O/C & 4 & OKC & $1 \times$ & 14 & & & \\
\hline
\end{tabular}


TABLE A-7. SINGLE-SHELL TANKS MONITORING COMPLIANCE STATUS 149 TANKS (Sheet 2 of 5)

Information as of 7/31/93

\begin{tabular}{|c|c|c|c|c|c|c|c|c|c|c|}
\hline \multirow{4}{*}{$\begin{array}{l}\text { Tank } \\
\text { Number }\end{array}$} & \multirow{2}{*}{\multicolumn{2}{|c|}{ Category }} & \multirow{4}{*}{$\begin{array}{l}\text { Temperature } \\
\text { Peadings } \\
\text { (5)(6) }\end{array}$} & \multirow{3}{*}{\multicolumn{2}{|c|}{$\begin{array}{l}\text { Surface Level } \\
\text { Readings (1) } \\
(-357)\end{array}$}} & \multirow{3}{*}{\multicolumn{2}{|c|}{$\begin{array}{c}\text { LOW Readings } \\
(-357)\end{array}$}} & \multicolumn{2}{|c|}{ Radlation Readings } & \multirow{4}{*}{$\begin{array}{c}\text { Dome } \\
\text { Elevation } \\
\text { Surveys } \\
\text { (OSPYSAR) }\end{array}$} \\
\hline & & & & & & & & \multirow{3}{*}{\begin{tabular}{|c|} 
Lateral \\
Readinges \\
$(-357)$
\end{tabular}} & \multirow{3}{*}{$\begin{array}{c}\text { Drywell } \\
\text { Readings } \\
\text { (OSPSAR) }\end{array}$} & \\
\hline & \multirow{2}{*}{$\begin{array}{l}\text { Watch } \\
\text { Lut(6) }\end{array}$} & \multirow{2}{*}{$\begin{array}{l}\text { Hion } \\
\text { Heat }\end{array}$} & & & & & & & & \\
\hline & & & & M.T. & FIC & Gamma & Noutron & & & \\
\hline $8 x-108$ & & & & & $\sqrt{5 \%}$ & \% $10 \%$ & 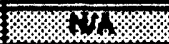 & \%W\% & & \\
\hline $8 x-100$ & & & & WW & & (1) & WW & 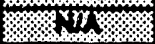 & & \\
\hline$E x-110(4)$ & & & \% & & IIS & $\mathrm{MTr} / 2$ & WW & SU\% & (1) & \\
\hline $8 x-111(4)$ & & & & & OU. & $18 \%$ & & WT & & \\
\hline$B X-112$ & & & & YU1\% & & $14 \%$ & 84W & IAC. & & \%ে. \\
\hline BY-101 (4) & & & & ONC & Nas & & & 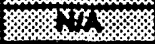 & & \\
\hline$B Y-102$ & & & O\&-OKC & & Wय & & & (24\% & & \\
\hline BY-103 & $\bar{x}$ & & & & $x \pi$ & থ & r. & 10 & \% & \\
\hline BY-104 & $\bar{x}$ & & & & Wक. & & & Mx & & \\
\hline$B Y-106$ & $\overline{\mathbf{x}}$ & & & & xy & & প & 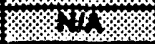 & ?. & \\
\hline BY-100 & $\bar{x}$ & & & & WUS & & & पTS & & \\
\hline BV-107 & $\bar{x}$ & & \% & & $\pi$ & ষৌ & m & lon & & \\
\hline $8 Y-100$ & $\bar{x}$ & & & & WM & 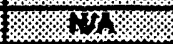 & 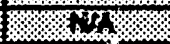 & Im & & \\
\hline BY-100 & & & $O E-O K C$ & VIr & & ( & ২. & $x$ & $\%$ & \\
\hline BY-110 & $\bar{x}$ & & & & WH: & 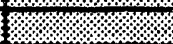 & 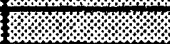 & WT: & & \\
\hline BY-111 & $\bar{x}$ & & ঋেফ & 28 & XIX & & & SWh & & ঋেফ \\
\hline BY-112 & $\bar{x}$ & & & & $8 \mathrm{XS}$ & orc & occ & STris: & & \\
\hline$c-101$ & & & & & XII & \%Ory & X्युs & 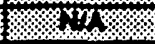 & & \\
\hline$C-102$ & & & orc & WWK & & \% W & YRr. & N48 & WA & \\
\hline$c-103$ & $\bar{x}$ & & & W & & 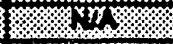 & 8 & Wro & & \\
\hline$C-104$ & & & & SWY & \%? & WUY & 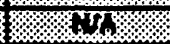 & 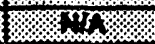 & & \\
\hline$c-106$ & & & & Wres & & 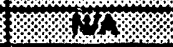 & $8 \%$ & 20 & ras & \\
\hline$C-100(A)$ & $\bar{x}$ & $\bar{x}$ & & WR & & IIIKR & $\mathbb{1 X}$ & XIM & \%. & \\
\hline$C-107$ & & & & $\mathrm{ver}$ & or & Why & 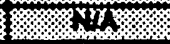 & 80 & 28 & 18 \\
\hline$c-100$ & $\bar{x}$ & & & & 5 & 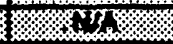 & 84 & (21\% & \%(\%) & \\
\hline$c-100$ & $\bar{x}$ & & & & 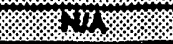 & 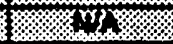 & W & 10 & (1) & \% \\
\hline$C-110$ & & & & & $4 x$ & W世. & STE & प1 & $1 \%$ & \\
\hline$c-111$ & $\bar{x}$ & & & & InT & Wha & W & 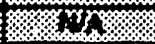 & & \\
\hline C-112 & $\bar{x}$ & & & & कास & WUS & $\sqrt{2 x}$ & Wh & & \% \\
\hline$c-201$ & & & & & xhx & WT & $\mathrm{BrH}$ & $x$ & r/ & \\
\hline$c-202$ & & & & & ITH & WA & 42 & 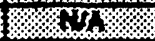 & & \\
\hline$C-203$ & & & & & $8 \mathrm{Wr}$ & nxt & 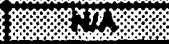 & XT & & ঋে \\
\hline C-204 & & & orc & & WA & INA & $\sqrt{428}$ & (WM: & ? & \\
\hline $8-101$ & & & & 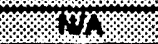 & & & & 50 & 18. & \\
\hline $8-102$ & $\bar{x}$ & & & WW & পা & 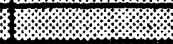 & & 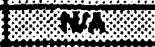 & & \% \\
\hline $8-103$ & & & ঋে & TLA & & & & Wrts: & \%: & \% \\
\hline $8-104$ & & & & & 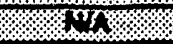 & Wr. & (1) WHS & NA & & \\
\hline $8-100$ & & & 88 & WWT & & 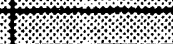 & min & $6 \mathrm{TH}$ & \%? & $\%$ \\
\hline $8-100$ & & & & IUR & & & & 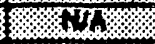 & & $\%$ \\
\hline $8-107$ & & & & 67 & & 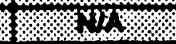 & 10 & WOS & & \\
\hline $5-108$ & & & & & & & & 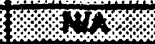 & & / \\
\hline $8-100$ & & & oc & WH & Ors (o) & & & $20 \%$ & & \\
\hline $8-110$ & & & & MW & & & & Krow & 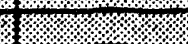 & \% \\
\hline क-111 & $\bar{x}$ & & ry & $42 \%$ & ore & & & YYT & & \\
\hline $8-112$ & $\bar{x}$ & & & WTS & & & & $\overline{R N}$ & X & $1 \% 1 \%$ \\
\hline $8 x-101$ & $\bar{x}$ & & & WW & & & স্যে & $x+1$ & & \\
\hline $8 x-102$ & $\bar{x}$ & & & XYX & ২: : & א. & 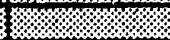 & \%W\% & & $\%$ \\
\hline $8 \times-103$ & $\bar{x}$ & & & XII & m & & & \%W & & ' \\
\hline $8 x-104$ & $\bar{x}$ & & & 848 & (1) & or-orc & वह- & STR & & 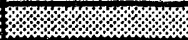 \\
\hline$\overline{x-106}$ & $\bar{x}$ & & ঋ & Wr & $8 \%$ & স্ষে & & orc & k & ky \\
\hline $8 x-100$ & $\bar{x}$ & & & 121. & Ox & & \% & 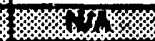 & 叕 & \% / . \\
\hline $8 x-107$ & & $x$ & কে & \% $/$ / & 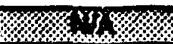 & 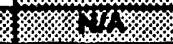 & twrty & OC & $7 \%$ & \% \\
\hline $8 x-10$ & & $\bar{x}$ & & \% / & কיক & W/Th\% & $\% / \% 1 \%$ & ox & & $1 / 1 \% \%$ \\
\hline
\end{tabular}


WHC-EP-0182-64

TABLE A-7. SINGLE-SHELL TANKS MONTORING COMPLIANCE STATUS 149 TANKS (She日t 3 of 5)

Information as of 7/31/93

\begin{tabular}{|c|c|c|c|c|c|c|c|c|c|c|}
\hline \multirow{4}{*}{$\begin{array}{l}\text { Tank } \\
\text { Number }\end{array}$} & \multirow{2}{*}{\multicolumn{2}{|c|}{ Category }} & \multirow{4}{*}{$\begin{array}{c}\text { Temperature } \\
\text { Readinos } \\
\text { (5)(6) }\end{array}$} & \multirow{3}{*}{\multicolumn{2}{|c|}{$\begin{array}{l}\text { Surface Level } \\
\text { Readings (1) } \\
\text { (-357) }\end{array}$}} & \multirow{3}{*}{\multicolumn{2}{|c|}{$\begin{array}{c}\text { LOW Raadings } \\
(-357)\end{array}$}} & \multicolumn{2}{|c|}{ Radiation Readings } & \multirow{4}{*}{$\begin{array}{c}\text { Dome } \\
\text { Eevation } \\
\text { Surveys } \\
\text { (OSR/SAR) }\end{array}$} \\
\hline & & & & & & & & \multirow{3}{*}{$\begin{array}{c}\text { Lateral } \\
\text { Readings } \\
(-357)\end{array}$} & \multirow{3}{*}{$\begin{array}{c}\text { Drywell } \\
\text { Readings } \\
\text { (OSR/SAR) }\end{array}$} & \\
\hline & \multirow{2}{*}{$\begin{array}{l}\text { Watch } \\
\text { Let(6) } \\
\end{array}$} & \multirow{2}{*}{$\begin{array}{l}\text { High } \\
\text { Hent }\end{array}$} & & & & & & & & \\
\hline & & & & T.T. & FTC & Gamma & Neutron & & & \\
\hline $8 x-100(4)$ & $x$ & $x$ & & & $\sqrt{15 x}$ & 646 & \% & Occ & & \\
\hline $8 x-110$ & & $\bar{x}$ & & & $12 \times$ & YYY & Yrs & orc & & \\
\hline $8 x-111$ & & $\bar{x}$ & & & 16. & 14 & 11\% & कर & & \\
\hline $8 x-112$ & & $\bar{x}$ & & & 14 & rox & 24 & क्ट & & \\
\hline $8 x-113$ & & & & & WH & 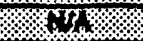 & 121 & $83 \times$ & & \\
\hline Sx-114 & & $\bar{x}$ & & & 10 & 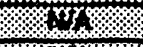 & 4 & ONC & & \\
\hline $8 x-116$ & & & O/8-OK & & 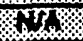 & W12 & ny & क्र & & \\
\hline $1-101(4)$ & & & & & & $\%$ & 20 & $8 \%$ & & \\
\hline T-102 & & & OS-OC & WT. & oc & 15\% & 128 & 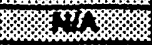 & & \\
\hline$T-103$ & & & & rts. & & WT & $8 \%$ & 2 & & \\
\hline$T-104$ & & & OR & & 97 & & & 54 & & \\
\hline$T-105$ & & & OS-OC & WX & & 14 & 84 & $\mathrm{KH}$ & & \\
\hline$T-103$ & & & & \%क\% & & 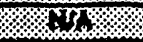 & 121 & 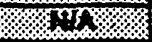 & & \\
\hline$T-107$ & $\mathbf{x}$ & & & 4 & & 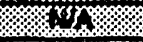 & 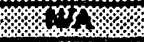 & 82 & & \\
\hline$T-103$ & & & OC & & 174. & W. & (n) & 198 & & \\
\hline$T-100$ & & & Oc & 10 & & 40 & 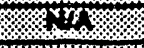 & $1 \%$ & & \\
\hline$T-110$ & $\bar{x}$ & & & \%4 & & 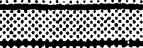 & & $\%$ & & \\
\hline$T-111$ & & & & Wrs & Ore & & & 110 & & \\
\hline$T-112$ & & & & 14 & & 84 & 84 & 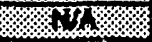 & & \\
\hline$T-201$ & & & & & 45 & 24 & $2 \%$ & 14 & & \\
\hline$T-202$ & & & & & 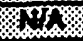 & $8 \%$ & 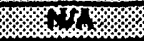 & 19. & & \\
\hline$T-203$ & & & & & 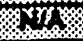 & 81 & 12 & $\times$ & & \\
\hline$T-204$ & & & & & 84 & 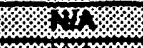 & 5 & 48 & & \\
\hline$T x-101$ & & & OIS-OL & $\%$ & & 10 & 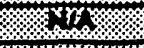 & $\times$ & & \\
\hline $7 x-102$ & & & OC & & 8 & & & 5 & & \\
\hline$\overline{x-103}$ & & & & 10 & & W & 818 & 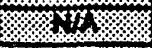 & & \\
\hline $7 x-104$ & & & & INA & & 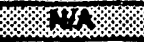 & Wrow & 54 & & \\
\hline $7 x-106$ & $\bar{x}$ & & & & 3 & OE-OIC & OE-OC & 80 & & \\
\hline $7 x-100$ & & & & & 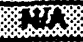 & & & 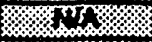 & & \\
\hline$T x-107$ & & & & 14 & & 84 & 4 & 84 & & \\
\hline$\overline{x-103}$ & & & & Wh & & & & It & & \\
\hline $7 x-100$ & & & & 28 & & & & 14 & & \\
\hline $7 x-110$ & & & oc & & 94 & & & 44 & & \\
\hline $7 x-111$ & & & & & $x$ & & & 10 & & \\
\hline $7 x-112$ & & & & & 40 & & & rrs & & \\
\hline $\bar{x}-113$ & & & & & $4 \%$ & & & 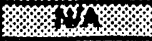 & & \\
\hline $7 x-114$ & & & Ox & & Wh: & & & Wh & & \\
\hline $7 x-116$ & & & & & 20 & & & 10 & & \\
\hline$\overline{x-110}$ & & & OISOK & & 4 & \&4. & $8 \times$ & $4 \%$ & & \\
\hline $7 x-117$ & & & OCC & & W & & & U. & & \\
\hline $7 x-118$ & $\bar{x}$ & & & 4 & & & & $\%$ & & \\
\hline$\pi r-101$ & $\bar{x}$ & & & 4 & & 4 & 4. & $\%$ & & \\
\hline$T Y-102$ & & & oc & sas. & & 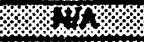 & 14\% & 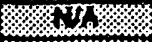 & & \\
\hline$T y-103$ & $x$ & & & 1 & & & & 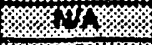 & & \\
\hline$T r-104$ & $\bar{x}$ & & & 48 & & ins: & प18 & $1 \times 4$ & & \\
\hline$\pi / 106$ & & & & & 14 & 8 & 40 & W. & & \\
\hline$T Y-100$ & & & & & 84 & 8 & MW & W\% & & \\
\hline U-101 & & & & & U. & 80 & 8 & 8 & & \\
\hline $0-102$ & & & & 179 & & 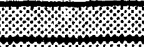 & & WA & & \\
\hline U-103 & $x$ & & & 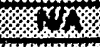 & & & & 1 & & \\
\hline U-104 & & & OS-OVC & & 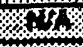 & 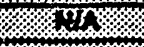 & $5 \quad$ & $4 \pi$ & & \\
\hline U-105 & $x$ & & & $4 y^{3}$ & & & & 4 & & \\
\hline $4-100$ & $x$ & & & $11 \%$ & & & & 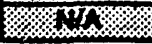 & & \\
\hline
\end{tabular}


TABLE A-7. SINGLE-SHELL TANKS MONITORING COMPLIANCE STATUS 149 TANKS (Sheet 4 of 5)

\begin{tabular}{|c|c|c|c|c|c|c|c|c|c|c|}
\hline \multirow{4}{*}{$\begin{array}{l}\text { Tank } \\
\text { Number }\end{array}$} & \multirow{2}{*}{\multicolumn{2}{|c|}{ Category }} & \multirow{4}{*}{$\begin{array}{c}\text { Temperature } \\
\text { Readings } \\
\text { (5)(6) }\end{array}$} & \multirow{3}{*}{\multicolumn{2}{|c|}{$\begin{array}{c}\text { Surface Level } \\
\text { Readings (1) } \\
(-357)\end{array}$}} & \multirow{3}{*}{\multicolumn{2}{|c|}{$\begin{array}{c}\text { Low Readings } \\
(-357)\end{array}$}} & \multicolumn{2}{|c|}{ Radiation Readings } & \multirow{4}{*}{$\begin{array}{c}\text { Dome } \\
\text { Elevation } \\
\text { Surveys } \\
\text { (OSRUSAR) }\end{array}$} \\
\hline & & & & & & & & \multirow{3}{*}{$\begin{array}{c}\text { Lateral } \\
\text { Readings } \\
(-357)\end{array}$} & \multirow{3}{*}{$\begin{array}{c}\text { Drywell } \\
\text { Readings } \\
\text { (OSPSAA) }\end{array}$} & \\
\hline & \multirow{2}{*}{$\begin{array}{l}\text { Watch } \\
\text { List(6) } \\
\end{array}$} & \multirow{2}{*}{$\begin{array}{l}\text { High } \\
\text { Heat }\end{array}$} & & & & & & & & \\
\hline & & & & M.T. & FIC & Gamma & Neutron & & & \\
\hline U-107 & $\bar{x}$ & & & $1+16$ & & & & \%WN & & \\
\hline U-108 & $\bar{x}$ & & & 148 & & & & 14X & & \\
\hline U-100 & $\bar{x}$ & & & 14 & $O / C$ & & & YH & & \\
\hline$U-110$ & & & & 14 & & $8 \%$ & 14 & 438 & & \\
\hline U-111 & & & & $N$ & & & & 14 & & \\
\hline U-112 & & & & & 142 & 108 & 138 & 14h & & \\
\hline U-201 & & & O/C & & $1 \%$ & 11. & 14 & X & & \\
\hline U-202 & & & & & 14: & 121 & N1X & 64 & & \\
\hline$U-203$ & & & $\mathrm{O} / \mathrm{C}$ & & 14 & 114 & 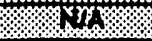 & $1 \%$ & & \\
\hline U-204 & & & O/C & & 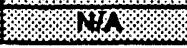 & 14 & N1\% & $\mathrm{MA}$ & & \\
\hline \multicolumn{11}{|c|}{ Catch Tanks and Special Surveillance Facillties } \\
\hline$A-302-A$ & NA & N/A & 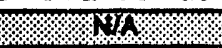 & $\%$ \% & & 13\% & 10 & $8 \mathrm{xm}$ & 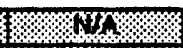 & Wr. \\
\hline$A-302-B$ & NA & NA & 121 & & 128 & 14X & 10 & 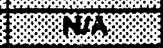 & 14 & m. \\
\hline 311-EA & NA & NA & 12 & H/2 & & 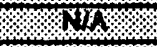 & N11 & U1\% & WA & 13X \\
\hline $152-\hat{A X}$ & N/A & N/A & Wr. & & +1 & & & & & \\
\hline $151-A Z$ & NA & N/A & $\times$ & 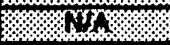 & $0 / S(\theta)$ & 14 & 148 & 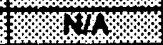 & $4 \times$ & $\mathrm{NH}$ \\
\hline $164-\Lambda Z$ & NIA & NA & 131 & & Frs & 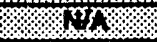 & 14 & 14 & W1 & HA \\
\hline BX-TKSMP & NA & N/A & 013 & & 48 & & & & & \\
\hline A-TKSMP & N/A & N/A & 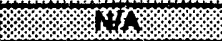 & & 6 & & & & & \\
\hline $204-A R$ & N/A & N/A & $\mathrm{N} / \mathrm{A}$ & & & & & & & \\
\hline $417-A$ & NA & N/A & 14 & & & & & & & \\
\hline Vent Sin. & NA & NA & N13 & & $01 \%$ & 119 & Nin & 40 & $\mathrm{Nm}$ & HIA \\
\hline $5-302$ & NA & NA & 11. & SIA & & W1 & 10 & 14 & 111 & 13 \\
\hline S-302-A & N/A & N/A & NIIX & us & O/C & rt & WH & 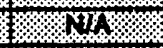 & WT & XIN \\
\hline S-304 & N/A & NA & 128 & & 128 & 13 & 114 & 48 & 110 & XI \\
\hline$T X-302-B$ & TWA & WA & 121 & O/C & 4 & 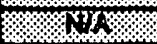 & NAM & MN & $\mathrm{XIN}$ & $\mathrm{Mm}$ \\
\hline $7 x-302-c$ & NA & NA & $4 \times$ & na & & 10 & N11 & W. & n: & $\mathrm{max}$ \\
\hline U-301-8 & NWA & NA & $\mathrm{NU}$ & NeN & O/C & 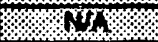 & NTR & $\mathrm{NA}$ & N4 & U1\% \\
\hline$U x-302-A$ & NA & N/A & $\mathrm{m}$ & $14 \times$ & & 14 & $\mathrm{XHA}$ & rrs & Wh & WA \\
\hline $141-S$ & NAA & N/A & NIX & & Wr & $\mathrm{NW}$ & $\mathrm{NH}$ & US & $\mathrm{NIA}$ & NIA \\
\hline $142-8$ & N/A & N/A & 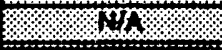 & & Wr & Nrs & rrs & WH & $\mathrm{NA}$ & $\mathrm{NT}$ \\
\hline \multirow{3}{*}{$\begin{array}{l}\text { Totals: } \\
140 \text { tanke }\end{array}$} & \multirow{3}{*}{$\begin{array}{c}44 \\
\text { Watch } \\
\text { Lidt } \\
\text { Tanks } \\
\text { (4) }\end{array}$} & \multirow{3}{*}{$\begin{array}{c}10 \\
\text { High } \\
\text { Heat } \\
\text { Tanks } \\
\text { (4) }\end{array}$} & \multirow{3}{*}{$\begin{array}{l}\text { OK: } \\
28 \text { tanke - } \\
\text { (cemiannual } \\
\text { monitoring } \\
\text { irequency) (5) }\end{array}$} & \multirow{3}{*}{$\begin{array}{l}\text { OrC: } \\
3 \text { tanke } \\
1 \text { catch tank }\end{array}$} & \multirow{3}{*}{$\begin{array}{l}\text { Orc: } \\
7 \text { tanks } \\
2 \text { catch tanks }\end{array}$} & OrC: & O/C: & \multirow{3}{*}{$\begin{array}{l}\text { Orc: } \\
12 \text { tanks }\end{array}$} & \multirow[t]{3}{*}{0} & \multirow[t]{3}{*}{0} \\
\hline & & & & & & $3 \tan k$ & 3 tanks & & & \\
\hline & & & & & & $\begin{array}{l}58 \text { tanks } h \\
\text { (2 are }\end{array}$ & $\begin{array}{l}\text { LOWs } \\
\text { (S) }\end{array}$ & & & \\
\hline
\end{tabular}

\section{See Footnotes on next page}




\section{Footnotes:}

1. All SSTs have either manual tape or FIC, with the exception of S-108 and T-101, which have both. Tank 101-T also has a zip cord. All SST FICs are connected to CASS, with the exception of BX-106; however, the connection for many tanks is broken. For such cases, manual readings are taken. Manual surface level readings include readings taken by monul tape, manuel fic (not connected to CASS; BX-106), manual readings of automatic FIC (if CASs is printing "ON), or autcomatic FIC. In some cases, the surface level readings are taken using a zip cord. While leas accurate, such readings are acceptable for meeting the surface level reading requirements.

2. Poychrometric readings are only taken on tanks with active oxhausters; high heat load tanks A-104/105, C-105/106 (effective July 1, 1993, C-105 is no longer a high heat lond tank), 5X-107, 108, 109, 110, 111, 112, and 114. The exhousters on $1-104 / 105$ have been down since October 1991; no readings are being taken. The frequency of psychrometric readings in SSTs are determined by the Cognizant Engineers for the applicable tank farms on an "os needed" basis," with the exception of Tanks C-105/106. Hanford Federal Facility Agreement and Consent Order, "Washington State Department of Ecology, U. S. Environmental Protection Agency, and U. S. Department of Energy, 1992 (Tri-Party Agreenent) requires psychrometric readings to be taken in C-105/106 on a monthly frequency. Tanks C-105/106 peychrometric readings are in compl iance through July 1993.

3. In-tank photographs are requested on an "as neededw basis. Wo in-tank photographs wore taken between 1991 and 1993.

4. Two tanks are on both category lists (C-106 and 5x-109). In July 1993, C-105 was ramoved fram the Migh Heat Land list and BX-110, BX-111, BY-101 and T-101 were removed from the ferrocyenide Watch ilist; these tanks continue to be monitored meekly. Temperature spikes occurred in BX-110 in July 1993. These erratic temperatures are being investigated.

5. Temperature readings may be regulated by OSD, -357 , or POP. Additionally, high heat load tanks are regulated by OSR/SAR. Thermocouples in the nine tanks designated O/S-O/C are out of service; there are either no thermocouple trees in these tanks, or trees hove been cut off, covered over, or are otherwise unable to function. The OSD does not require reedings or repair of out-of service thermocouples for the 97 low heat losd $(440,000$ Btu/h) tenks. Mowever, the POP requires that attempts are to be made semiennually in Jenuary and July to obtoin readinge for these tanks. Temperatures were taken in July 1993; a total of 26 tanks are O/C because either no attempt to obtain the temperature was made, or a reading could not be obtained.

6. wSafety Measures for Waste Tenks at Henford Muclear Reservation, Section 3137 of the Mational Defense Authorization Act for Fiscal Year 1991, "November 5, 1990, Public Law 101-510, (the muiden Amendibent") requires continuous pressure monitoring and temperature monitoring in Watch List tanks. WHC-EP-0422 REV 1, WA PI an to Implement Rewadiotion of Waste Tenk Safety Isesues ot the Henford Site," Decenber 1991, addresses these monitoring issues. A status report on resolution of waste Tank Safety lesves of the Henford site is boing prepored and is expocted to be iseund in Alowst 1993.

7. Continuous Air Monitoring (CAN) complience and Rediation Area Monitoring Panel (RAMP) compliance are not addressed in this table.

8. Double-shell tank farm SY has the only tenks with continuous vapor/flemable gas monitoring; not addressed in this table.

9. S-109 is $0 / 5$ but will become $0 / C$ on 8/2/93. 151-AZ cetch tenk - using Zip cord reading. 


\section{TABLE A-8. DOUBLE-SHELL TANKS MONITORING COMPLIANCE STATUS 28 TANKS (Sheet 1 of 2)}

The following table indicates whether Double-Shell tank monitoring was in compliance with the requirements as specified in the applicable documents as of the last day of the applicable month:

NOTE:

Dome Eevation Sunveye are not required for DSTs.

Poyshrometrics (2)

In-tank Photographs (3)

Prescure Monitoring (8)

CAM/RAMP Monitoring (7)

Vapor Monitoring (8)

\begin{tabular}{|c|c|}
\hline REGEND: & = In compliance with all applicable documentation \\
\hline ÓC & $=$ Out of compliance with documentation \\
\hline-357 & $\begin{aligned}= & \text { WHC-SD-WM-TI-357. "Waste Storage Tank Status and Leak } \\
& \text { Detection Criteria" }\end{aligned}$ \\
\hline M.T. & = Manual Tape \\
\hline FIC & = Food Inetrument Company \\
\hline OSR/SAR & $\begin{array}{l}=\text { Operations Safety Requiremente/Safety Analyeis Report } \\
\text { WHC-SD-WM-SAR-018, Rev 1, 5/86 } \\
\text { WHC-SD-HS-SAR-010, Rev 1, 6/83 (Aging Wacte) }\end{array}$ \\
\hline OSO & $=$ Operatione Safety Doc., OSD-T-151-0007, Rov H-5, 1/92 \\
\hline NA & - Not Applicable (i.e., no M.T., FIC installed) \\
\hline O/S & = Out of Service \\
\hline W.F. & = Woight Factor \\
\hline Rad. & = Radiation \\
\hline
\end{tabular}

Information as of 7/31/93

\begin{tabular}{|c|c|c|c|c|c|c|c|}
\hline \multirow{3}{*}{$\begin{array}{l}\text { Tank } \\
\text { Number }\end{array}$} & \multirow[b]{3}{*}{ Watch List } & \multirow{3}{*}{$\begin{array}{c}\text { Temperature } \\
\text { Readings } \\
\text { (4) } \\
\text { (OSD) }\end{array}$} & \multirow{2}{*}{\multicolumn{2}{|c|}{$\begin{array}{l}\text { Surface Level } \\
\text { Readings (1) } \\
\text { (-357, OSR/SAR) }\end{array}$}} & \multicolumn{3}{|c|}{ Radiation Readings } \\
\hline & & & & & \multicolumn{2}{|c|}{$\begin{array}{c}\text { Leak Detection } \\
\text { Pits (5) } \\
\text { (-357, OSR/SAR) }\end{array}$} & \multirow{2}{*}{$\begin{array}{c}\text { Annulus } \\
(-357) \\
\end{array}$} \\
\hline & & & M.T. & FIC & W.F. & Rad. & \\
\hline$A N-101$ & & & W. & & & & \\
\hline AN-102 & & & 10 & & & O/C & \\
\hline$A N-103$ & $\bar{x}$ & & 18 & & & & \\
\hline AN-104 & $\bar{x}$ & & WH & & & OIC & \\
\hline AN-105 & $\bar{x}$ & & 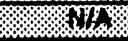 & & & & \\
\hline$A N-106$ & & & 1 & & & \% & \\
\hline AN-107 & & & N12 & & & 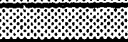 & \\
\hline AP-101 & & & & & & OIC & \\
\hline AP-102 & & & & o/s & & OIC & \\
\hline$A^{P}-103$ & & & & & & OKC & \\
\hline AP-104 & & & $0 / 5$ & & & OIC & \\
\hline AP-105 & & & & & & OIC & \\
\hline AP-108 & & & & & & ORC & \\
\hline AP-107 & & & & & & O/C & \\
\hline AP-108 & & & & & & OK & \\
\hline$A W-101$ & $\bar{x}$ & 8. & & O/S & & & \\
\hline AW-102 & & & & O/S & & \% & \\
\hline$A W-103$ & & & & O/S & & $\%$ & \\
\hline \multicolumn{8}{|l|}{$A W-104$} \\
\hline AW-105 & & & & O/S & & & \\
\hline \multicolumn{8}{|l|}{ AW-108 } \\
\hline$A Y-101$ & & & & O/S & & & OIC \\
\hline AY-102 & & & & & & $O K C$ & OIC \\
\hline AZ-101 & & & & O/S & & O/C (9) & \\
\hline$\overline{A Z-102}$ & & & & O/S & & & \\
\hline SY-101 & $\bar{x}$ & & & & & & \\
\hline \multicolumn{8}{|l|}{$8 Y-102$} \\
\hline SY-103 & $\bar{x}$ & & & o/s & & & \\
\hline $\begin{array}{l}\text { Totale: } \\
28 \text { tanke }\end{array}$ & $\begin{array}{c}c \\
\text { Watch Litt Tanks }\end{array}$ & OrC: & $\begin{array}{l}\text { Orc: } \\
0\end{array}$ & $\begin{array}{l}\text { Orc: } \\
0\end{array}$ & $\begin{array}{l}\text { OrC: } \\
0\end{array}$ & $\begin{array}{l}\text { O/C: } \\
12 \text { tanks }\end{array}$ & $\begin{array}{l}\text { Orc: } \\
2 \text { tunks }\end{array}$ \\
\hline
\end{tabular}

See footnotes next page: 


\section{TABLE A-8. DOUBLE-SHELL TANKS MONITORING COMPLIANCE STATUS}

\section{TANKS (Sheet 2 of 2 )}

\section{Footnotes:}

1. All DSTs have both manual tape and FIC, with the exception of the AN Tank Farm which has only FICs. The manual tape is used when the FIC is out of service. O/C will be shown when no readings are obtained.

2. Psychrometric readings are only taken on tanks with active exhausters; all DSTs have active exhausters. The frequency of psychrometric readings in DSTs are determined by the Cognizant Engineers for the applicable tank farms on an "as needed" basis. Currently, monthly readings are being taken on the SY-101 annulus exhaust, SY-102 tank and annulus exhaust, and SY-103 tank and annulus exhaust. SY-101 tank exhaust readings are not being taken until a port on the tank exhaust header becomes available for exhauster readings. No other psychrometric readings are currently being taken monthly.

3. In-tank photographs are requested on an "as needed" basis. Last in-tank photographs in DSTs were taken in April 1989.

4. OSD specifies DST temperature limits, gradients, etc. Tank SY-101 temperatures are obtained shiftwise with increased readings taken prior to and following gas venting.

5. Failure of both lead detection systems requires repair of at least one system within 5 working days. Failure of one system only, repair must be within 10 workdays. Per -357. If repair of out-ofservice system exceeds these timeframes, all systens are O/C. Out-of-service systems which have not exceeded these timeframes will be shown as $0 / 5$.

6. "Safety Measures for Waste Tanks at Hanford Nuclear Reservation, Section 3137 of the National Defense Authorization Act for Fiscal Year 1991," November 5, 1990, Public Law 101-510, (the "Widen Amendment") requires continuous pressure monitoring and temperature monitoring in Watch List tanks. WHC-EP-0422 REV 1 "A Plan to Implement Remediation of Waste Tank Safety Issues at the Hanford site," December 1991, addresses these monitoring issues. A status report on resolution of Waste Tank Safety Issues ot the Hanford site is being prepared and is expected to be issued in August 1993.

7. Continuous Air Monitoring (CAM) compliance and Radiation Area Monitoring Panel (RAMP) compliance are not addressed in this table.

8. Double-shell tank farm SY has the only tanks with continuous vapor/flammable gas monitoring; not addressed in this table.

9. Although data are being received for AZ-101, these are considered questionable. 
TABLE A-9. AUTOMATIC FOOD INSTRUMENT CORPORATION (FIC) GAUGES OUT OF SERVICE July 31, 1993

Date of Last

Automatic

Tank No. SST/DST FIC Reading

Reading Status

Required

Monitoring

\begin{tabular}{|c|c|c|c|c|c|c|}
\hline$\frac{B x-107}{c-107}$ & $\begin{array}{l}\text { SST } \\
\text { SST }\end{array}$ & $12 / 30 / 92$ & $\begin{array}{l}\text { No reading taken since 04/19/93 } \\
\text { No reading taken since 06/14/93 }\end{array}$ & & $\begin{array}{l}\text { Out of compliance as of 04/26/93 } \\
\text { Out of compliance as of } 06 / 21 / 93\end{array}$ & $\begin{array}{l}\text { Weekly } \\
\text { Woekly }\end{array}$ \\
\hline$\frac{c-107}{\text { s-109 }}$ & $\begin{array}{l}\text { SST } \\
\text { SST }\end{array}$ & $06 / 14 / 93$ & $\begin{array}{l}\text { No reading taken since } 06 / 14 / 93 \\
\text { No reading taken since 07/26/93 }\end{array}$ & & In Compllance & Weekly \\
\hline$\frac{5-111}{3-100}$ & SST & $07 / 9 / 93$ & No reading taken since 07/19/93 & & Out of compliance as of $07 / 20 / 93$ & Dally \\
\hline $5 x-106$ & SST & $071 / 9 / 93$ & No reading taken since 07/19/93 & & Out of compliance as of $07120 / 93$ & Dally \\
\hline$T-102$ & SST & $06 / 07 / 93$ & No reading taken since 06/07/93 & & Out of compliance as of $06 / 07 / 93$ & Quartenly \\
\hline$T-111$ & SST & 071293 & No reading taken since 03/29/93 & & Out of compliance as o $04 / 07 / 93$ & Quarterly \\
\hline U-109 & SST & $07 / 17 / 93$ & No reading taken since $07 / 71 / 93$ & & Out or compliance as of 0711293 & Daily \\
\hline B-Farm & SST & 07/06/93 & Taking manual FiC readings & & In compliance & Quarterly \\
\hline BY-109 & SST & $07 / 17 / 93$ & Taking manual FIC readings & & In compliance & Weekly \\
\hline T-Substation & - & $05 / 28 / 93$ & Taking manual fic readings & & In compliance & W/M/O \\
\hline$C-105$ & SST & $0609 / 93$ & Taking manualfic readings & & In compliance & Daily \\
\hline 5Y-101 & DST & $08 / 23 / 97$ & Taking manual FIC readings & & In compliance & Daily \\
\hline$T-103$ & SST & $11 / 15 / 91$ & Taking manual FIC readings & & In compliance & Quaiterly \\
\hline$T-103$ & SST & $03 / 31 / 93$ & Taking manual FIC readings & & In compliance & Quârenty \\
\hline U-105 & SST & 11/77/92 & Taking manual FIC readings & & In compliance & Weekly \\
\hline AP-102 & DST & $01 / 27 / 93$ & Taking manual tape readings & & In compliance & Daily \\
\hline AW-10T & DST & $70 / 23192$ & Taking manual tape readings & & In compllance & Daily \\
\hline$A W-102$ & DST & $0616 / 93$ & Taking manual tape readings & & Tn compliance & Daily \\
\hline AW-103 & DST & $03 / 21 / 92$ & Taking manual tape readings & & In compliance & Daily \\
\hline$A W-105$ & DST & $06 / 8 / 93$ & Taking manual tape readings & & Tn compliance & Daily \\
\hline AY-10T & DST & $08 / 31 / 90$ & Taking manual tape readings & & In compliance & Daily \\
\hline AZ-101 & DST & 02102290 & Taking manual tape readings & & In compliance & Daily \\
\hline AZ-102 & DST & $02 / 5 / 90$ & Taking manual tape readings & & In compliance & Daily \\
\hline SY-103 & DST & $07 / 05 / 93$ & Taking manual tape readings & & In compliance & Daily \\
\hline$T-101$ & SST & 1202191 & Taking manual tape readings & & Tn compliance & Daily \\
\hline \multicolumn{7}{|l|}{ Gan Sanks } \\
\hline \multicolumn{2}{|l|}{$A-302-A$} & $04 / 16 / 91$ & Taking manual FIC reading & & In compliance & Daily \\
\hline \multirow{2}{*}{\multicolumn{2}{|c|}{$\begin{array}{l}151-A Z \\
U-301-B\end{array}$}} & $07 / 29 / 93$ & Taking Zip Cord reading & & In compliance & Shift \\
\hline & & $03 / 23 / 93$ & No reading taken since 04/29/93 & & Out ol compliance as of $04 / 30 / 93$ & Daily \\
\hline \multicolumn{4}{|c|}{$\begin{array}{l}\text { Frequency reading requirements: } \\
\text { Daily - Must be taken by } 2 \text { pm each d } \\
\text { Weekly - Must be taken by } 2 \text { pm each } \\
\text { Quarterly - Must be taken by } 2 \text { pm on }\end{array}$} & KEGEND & \multicolumn{2}{|c|}{ 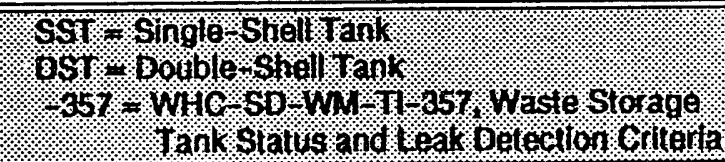 } \\
\hline
\end{tabular}


WHC-EP-0182-64

This page is intentionally left blank

A-22 
WHC-EP-0182-64

\section{APPENDIX B}

\section{DOUBLE SHELL TANK WASTE TYPE AND SPACE ALLOCATION}




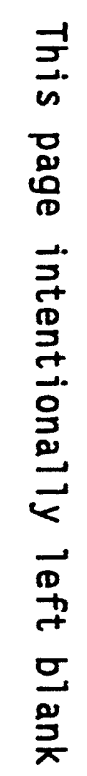


TABLE B-1. DOUBLE-SHELL TANK WASTE TYPE AND SPACE ALLOCATION JULY 1993

DOUBLE-SIIELL TANK INVENTORY BY WASTE TYPE

SPACE DESIGNATED FOR SPECIFIC USE

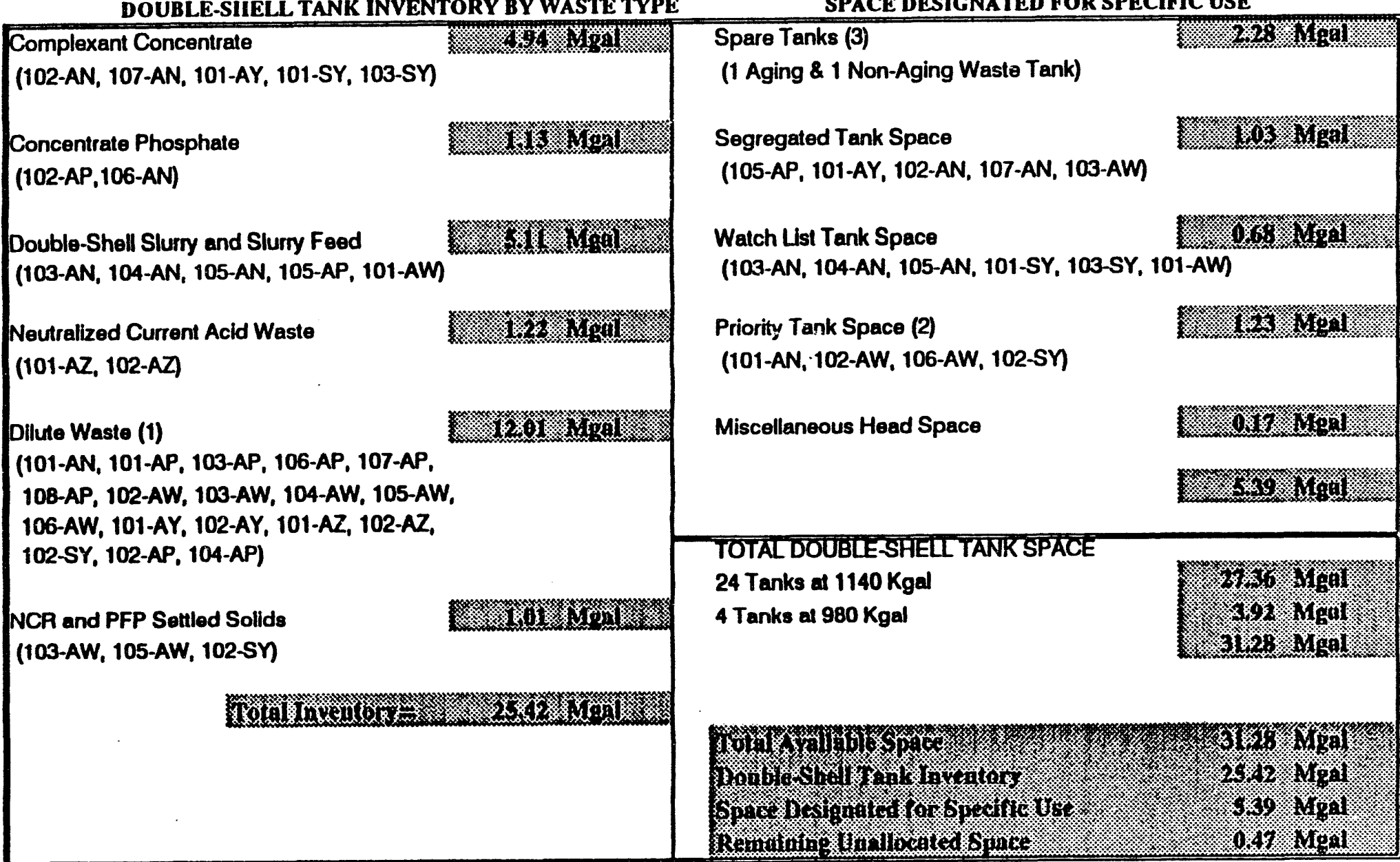

(1) Easily reduced in volume by EvaporatorRERF

(2) Reduced by Saltwell Liquid pumping. Mini Run and PFP Operations

(3) 241-101-AY: A minumum liquid level is set to provide extra protection against any bottom uplifting of the tank's steel liner. WHC-SD-WM-TI-357,

Waste Storage Tank Status and Leak Detection Criteria," specifies $64 \mathrm{in.} \mathrm{as} \mathrm{the} \mathrm{minimum} \mathrm{surface} \mathrm{level} \mathrm{measurement} \mathrm{when} \mathrm{the} \mathrm{annulus} \mathrm{system} \mathrm{is}$

in operation, and $18 \mathrm{ln}$. if the annulus ventilation system is shut down. See also OSD-T-151-0007, Unclassified Operation Specifications for the 241 AN, 241AP, 241AW, 241AY and 241SY Tank Farms." Because of space availablitity, waste is stored in 102-AY, the aging waste spare tank. In case of a leak, the contents of 102-AY will be distributed to any other DST(s) having available space.

Note: Net change in DSTs since last month: $22 \mathrm{Kgal}$. 


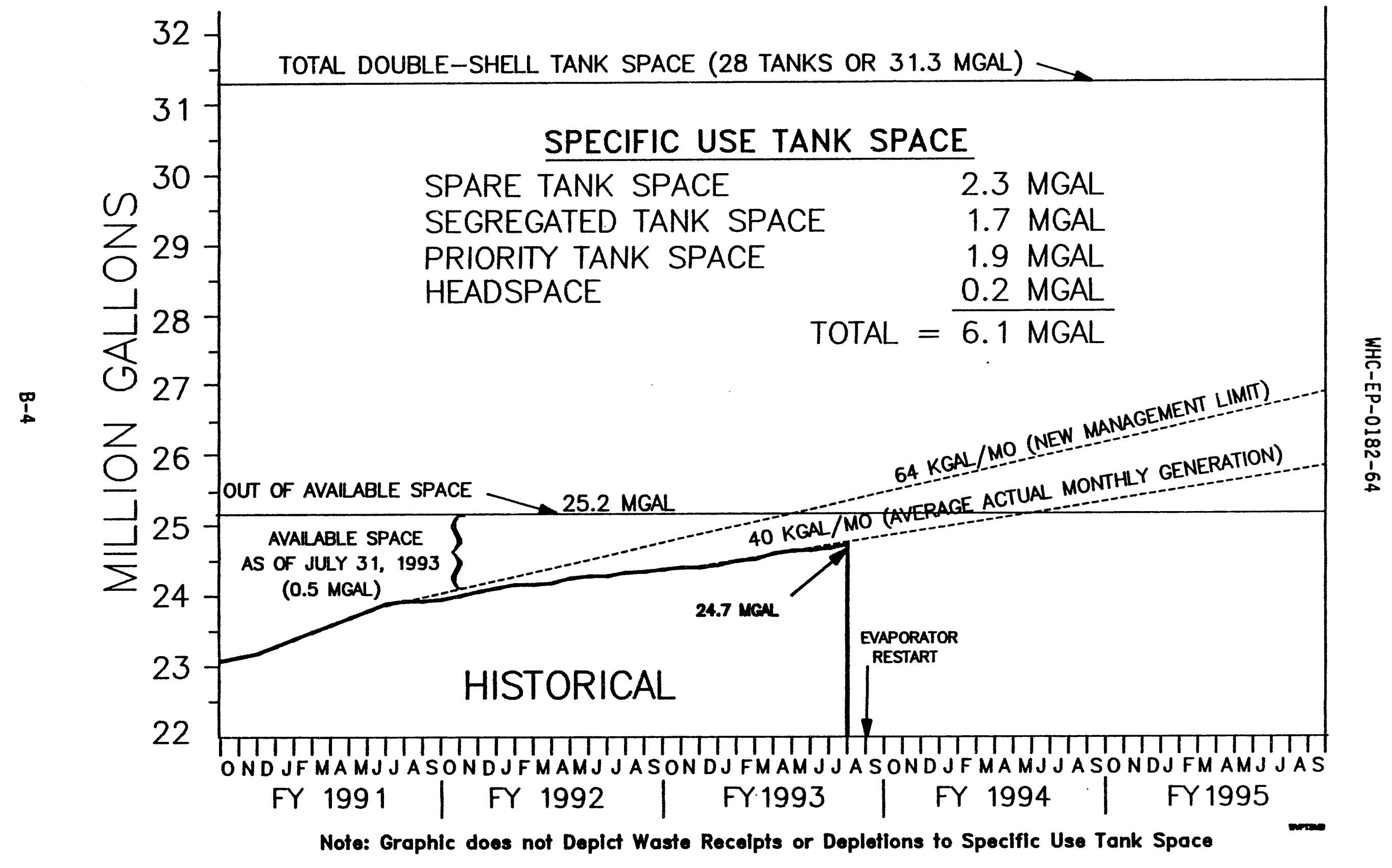

FQURE B-1. CUARENT STATUS AND CONTINGENCY BPACE FOR THE 2A2-A gVAPORATOR RESTART 


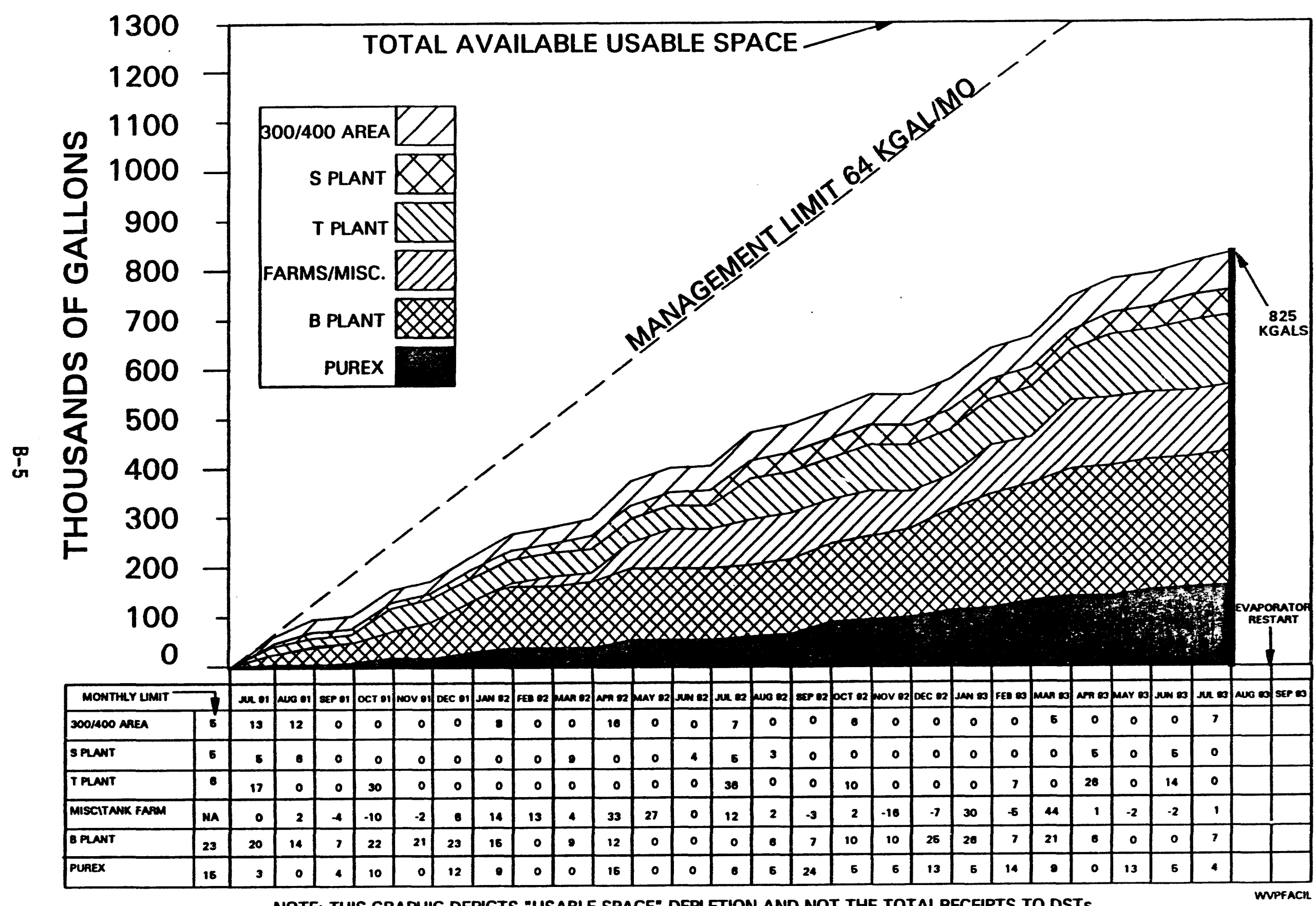
FIGURE B-2. TOTAL AVAILABLE USABLE TANK SPACE 


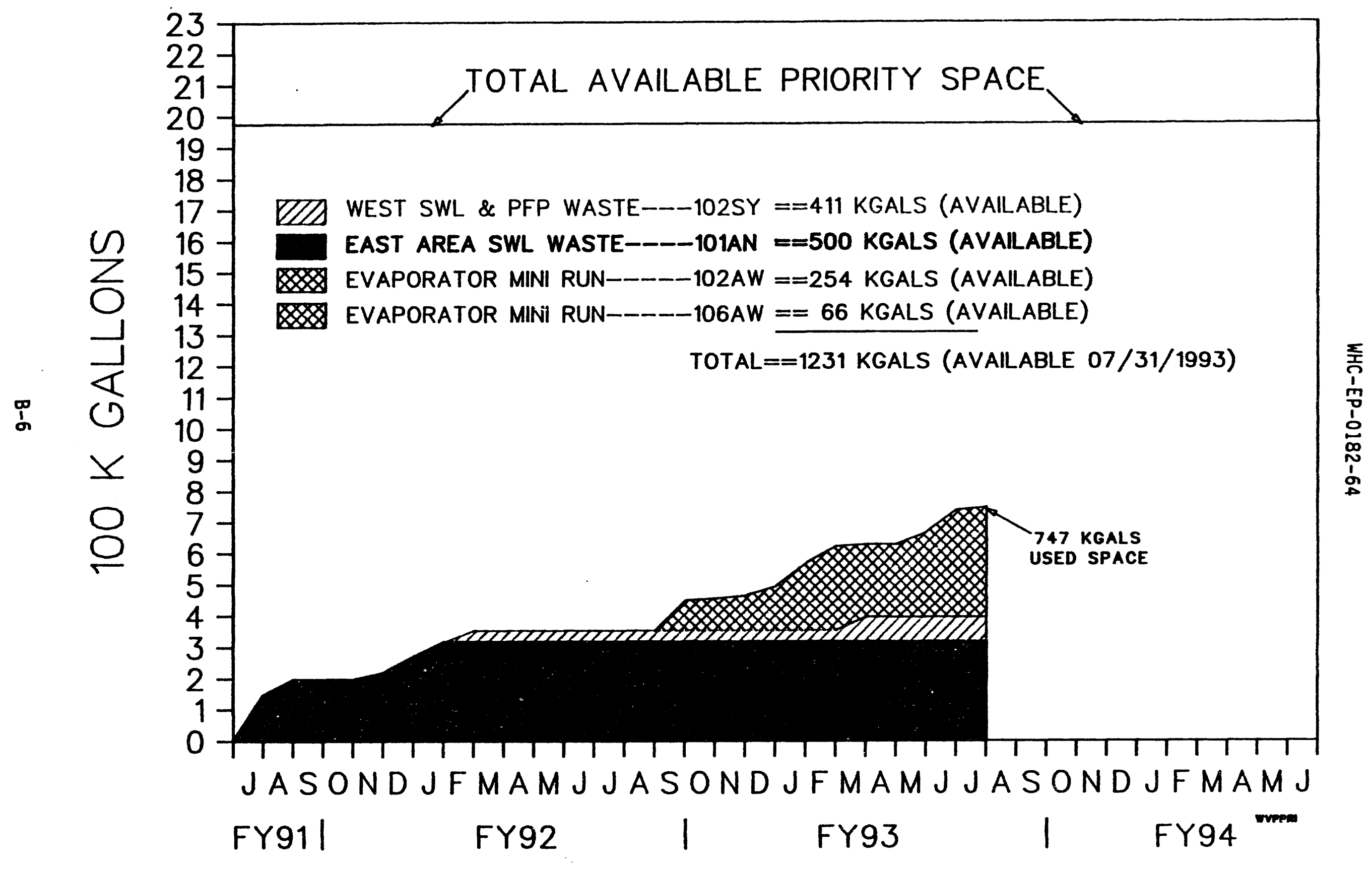

FIGURE B-3. PRIORITY SPACE AVAILABILITY AND USAGE 


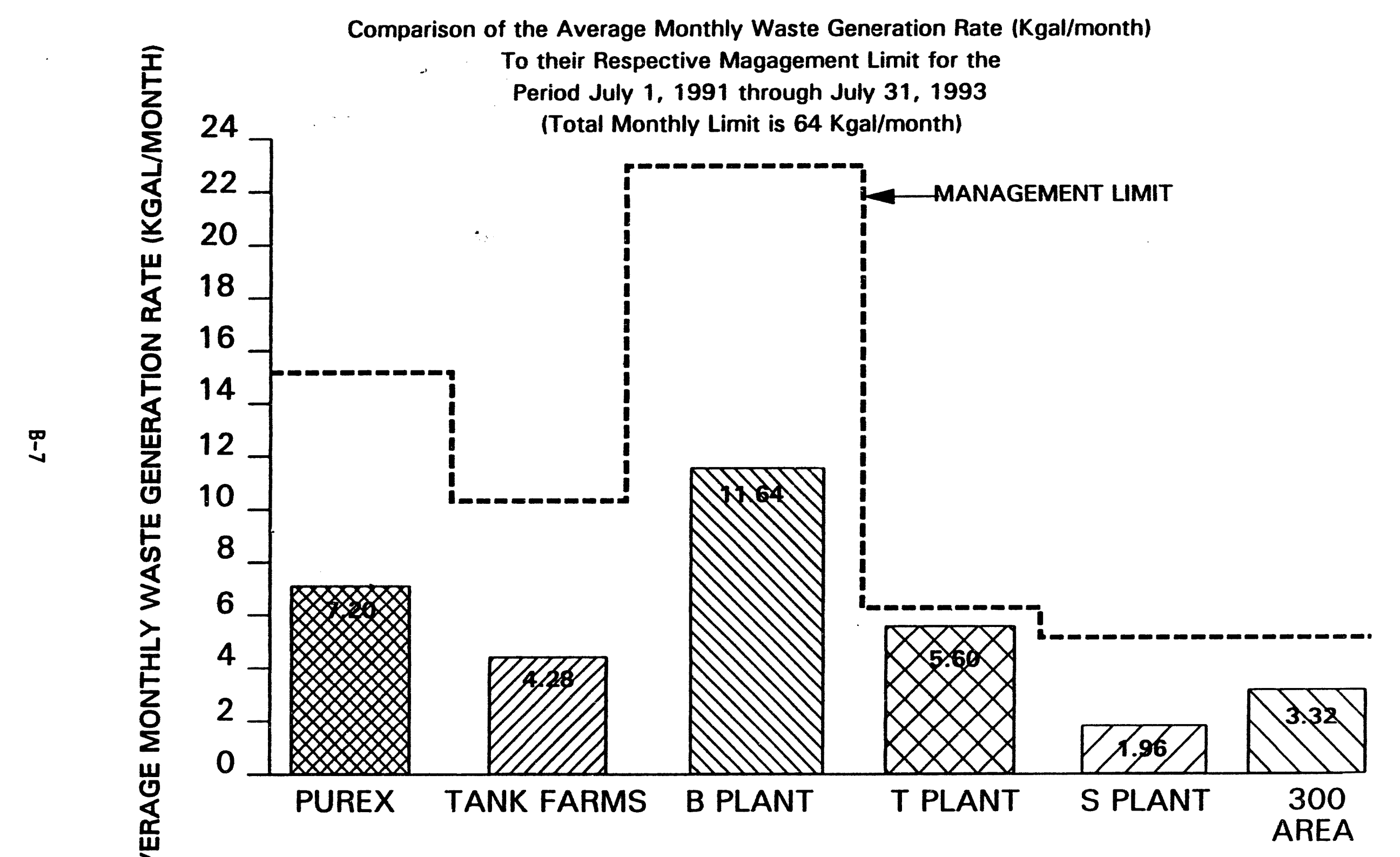

Figure B-4. Comparison of Monthly Average Waste Generation to Management Limit by Facility 


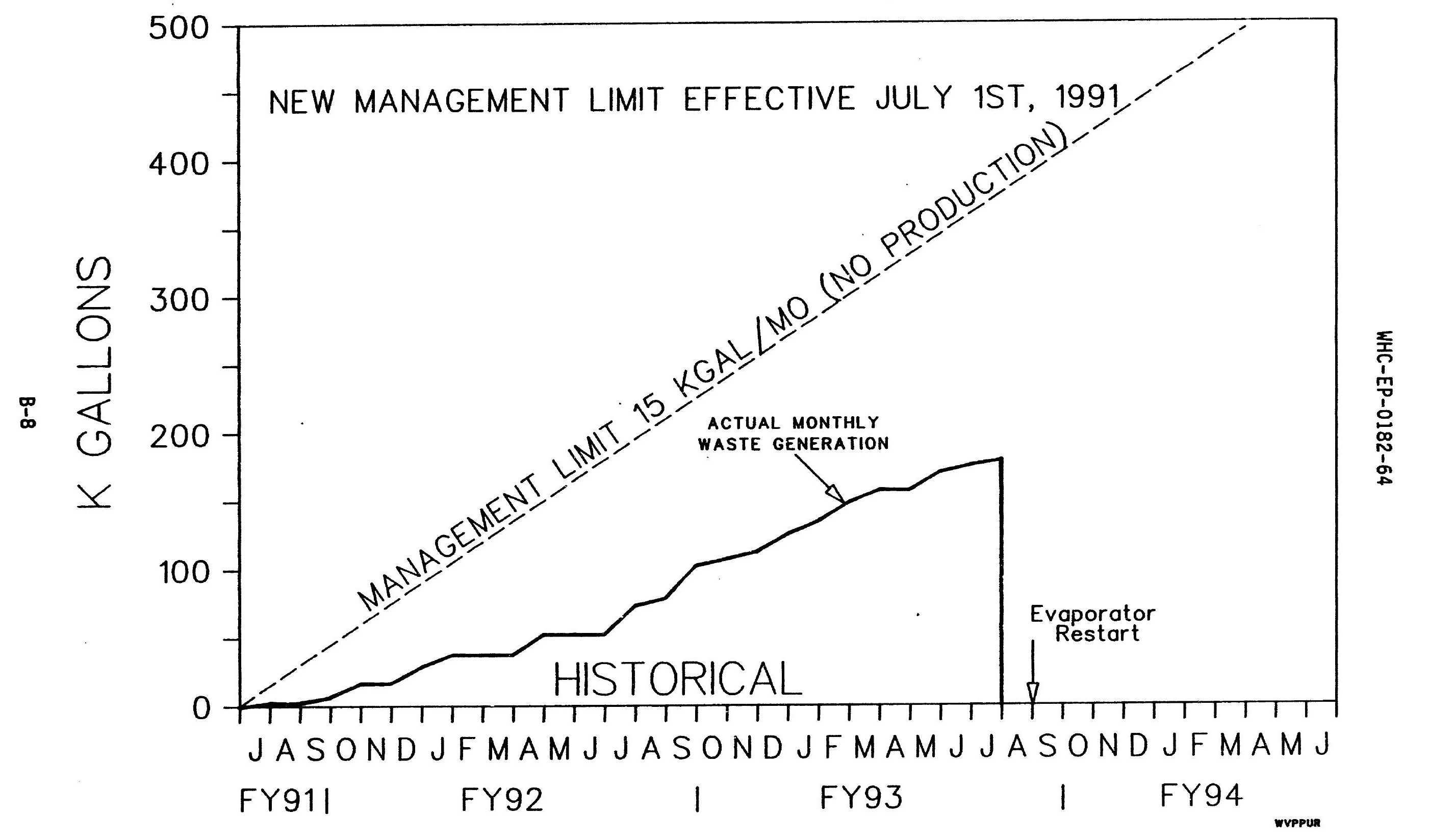

FIGURE B-5. PUREX MONTHLY WASTE GENERATIONS 


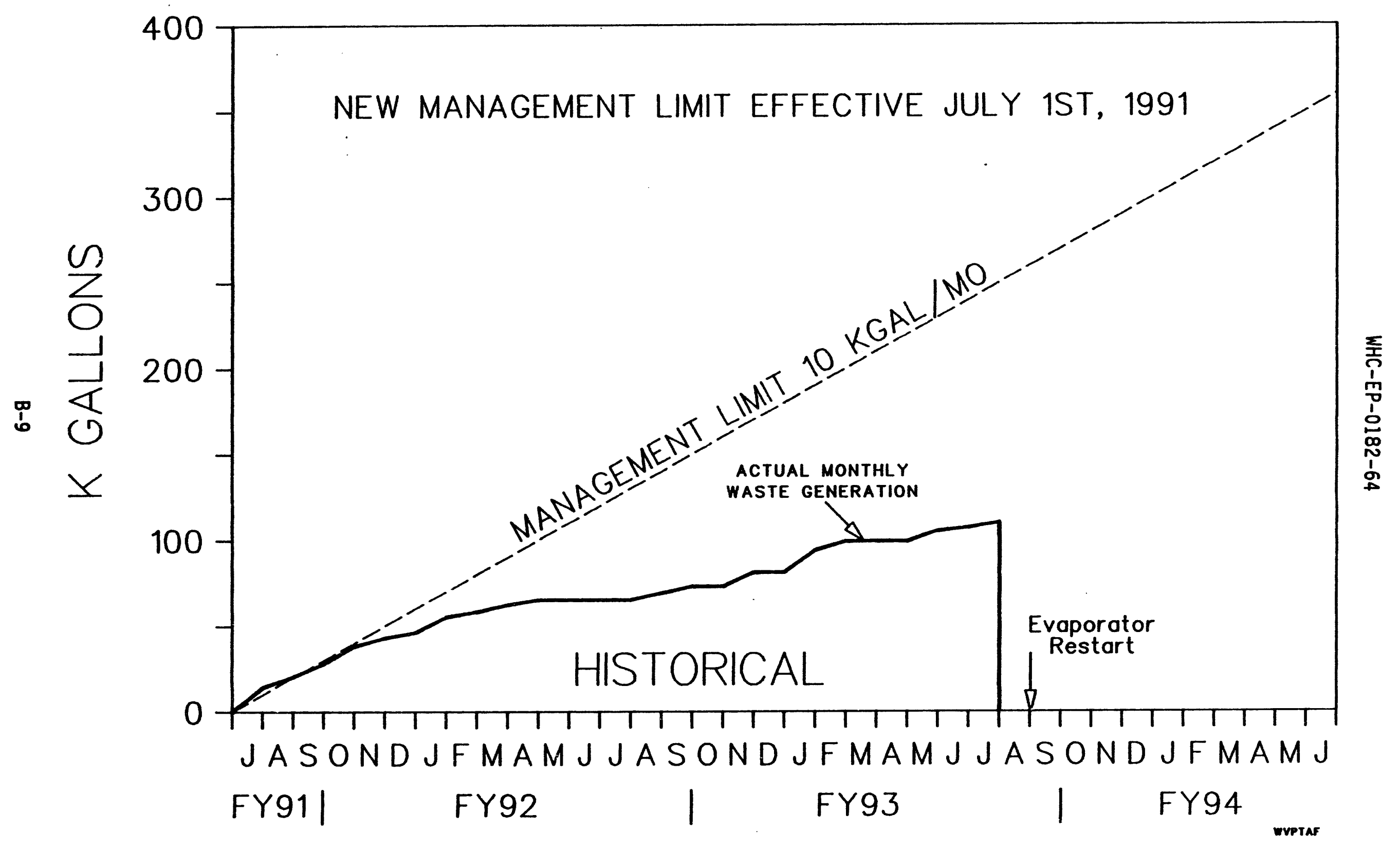

FIGURE B-6. TANK FARM MONTHLY WASTE GENERATIONS 


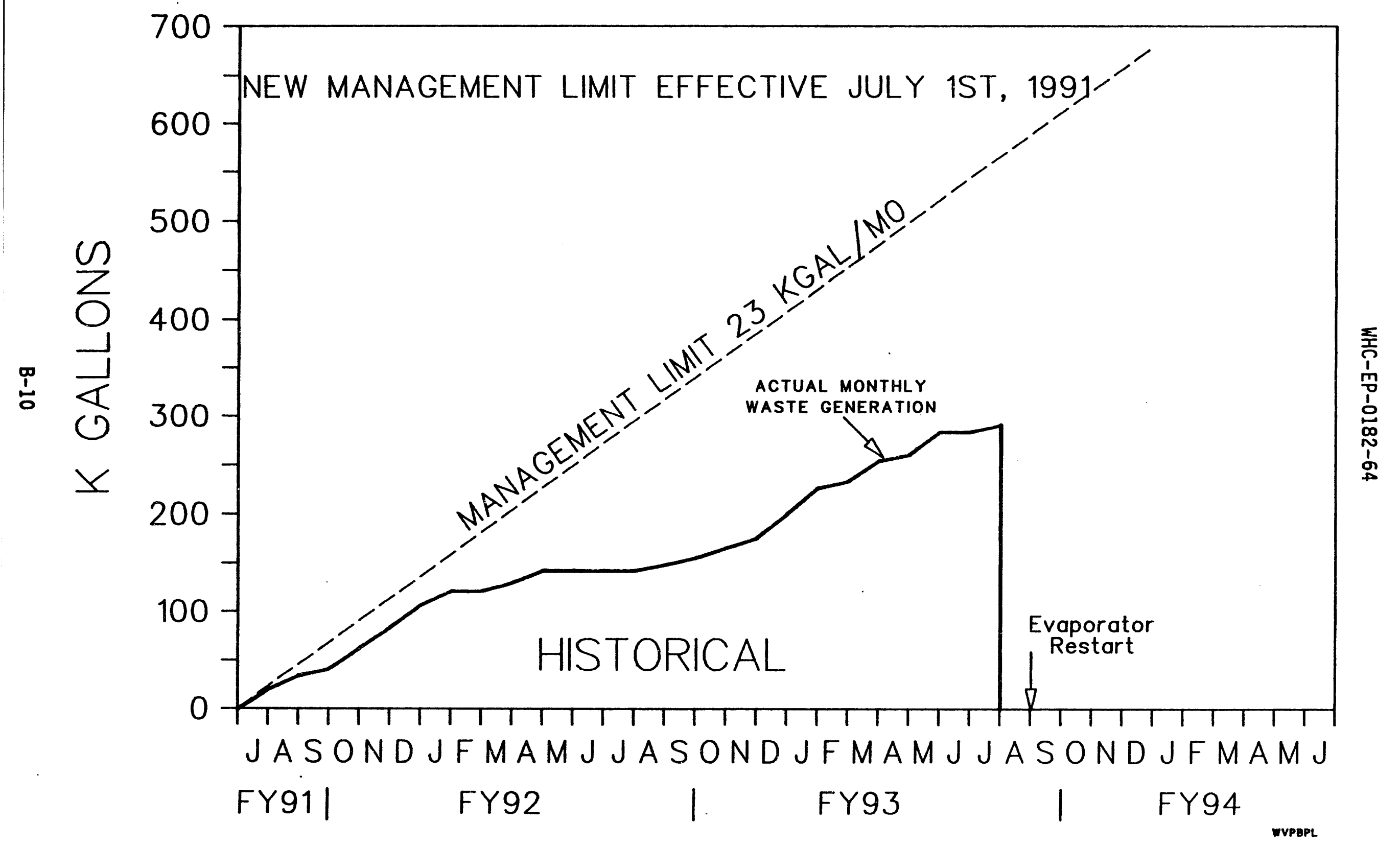

FIGURE B-7. B PLANT MONTHLY WASTE GENERATIONS 


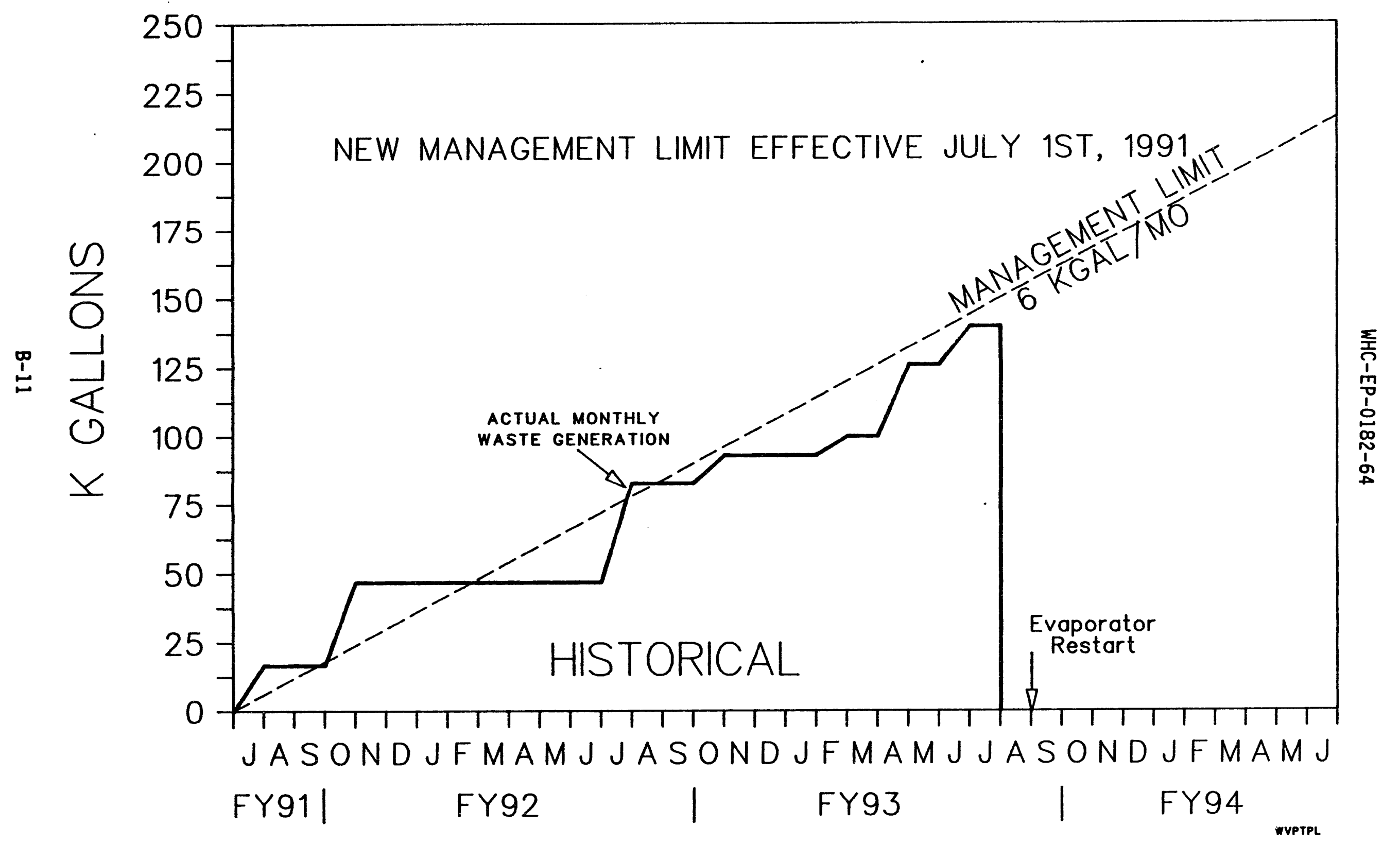

FIGURE B-8. T PLANT MONTHLY WASTE GENERATIONS 


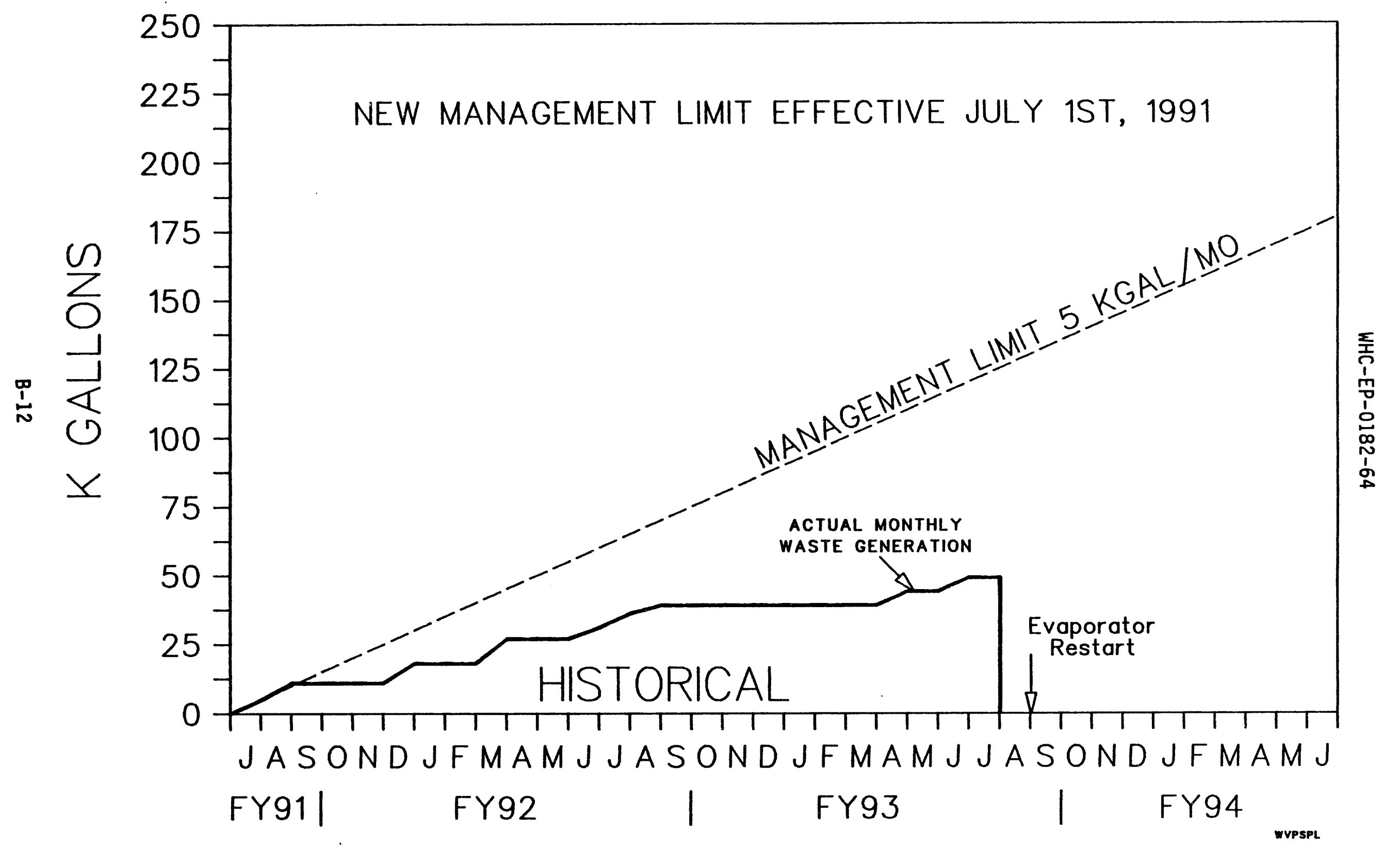

FIGURE B-9. S PLANT MONTHLY WASTE GENERATIONS 


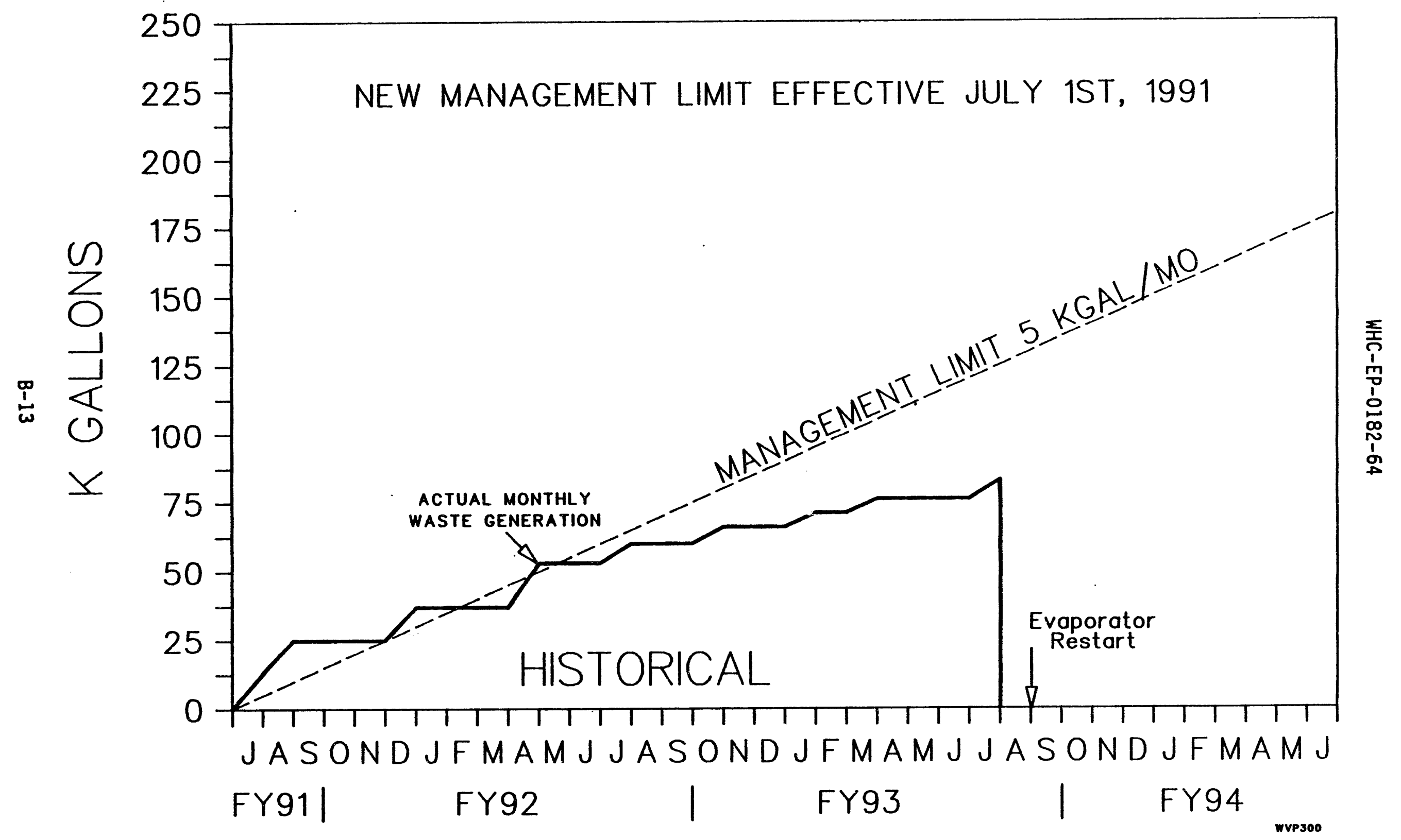

FIGURE B-10. 300 AREA MONTHLY WASTE GENERATIONS 
Table B-2. Double Shell Tank Waste Inventory for July 31, 1993 (page 1 of 2)

\begin{tabular}{|c|c|c|c|c|}
\hline TANKS & INVENTORY & SOLIDS & TYPE & LEFT \\
\hline$\overline{101 \mathrm{AW}}=$ & 1151 & 84 & DSSF & -11 \\
\hline $102 \mathrm{AW}=$ & 886 & 3 & DN & 254 \\
\hline $103 A W=$ & 645 & 487 & PD/DN & 495 \\
\hline $104 A W=$ & 1124 & 267 & DN & 16 \\
\hline $105 \mathrm{AW}=$ & 1002 & 388 & PD/DN & 138 \\
\hline $106 \mathrm{AW}=$ & 1074 & 211 & DN & 66 \\
\hline $101 \mathrm{AY}=$ & 908 & 83 & $D C$ & 72 \\
\hline $102 \mathrm{AY}=$ & 849 & 32 & DN & 131 \\
\hline $101 \mathrm{AZ}=$ & 969 & 35 & NCAW & 11 \\
\hline $102 A Z=$ & 960 & 95 & NCAW & 20 \\
\hline $101 \mathrm{AN}=$ & 640 & 0 & DN & 500 \\
\hline 102AN $=$ & 1101 & 89 & CC & 39 \\
\hline $103 \mathrm{AN}=$ & 951 & 373 & DSS & 189 \\
\hline $104 \mathrm{AN}=$ & 1064 & 264 & DSSF & 76 \\
\hline $105 \mathrm{AN}=$ & 1129 & 0 & DSSF & 11 \\
\hline $106 A N=$ & 23 & 17 & $C P$ & 1117 \\
\hline $107 \mathrm{AN}=$ & 1068 & 134 & $\mathrm{CC}$ & 72 \\
\hline $101 S Y=$ & 1109 & 560 & $\mathrm{CC}$ & 31 \\
\hline $102 S Y=$ & 729 & 133 & PT/DN & 411 \\
\hline $103 S Y=$ & 755 & 4 & CC & 385 \\
\hline $101 \mathrm{AP}=$ & 1061 & 0 & DN & 79 \\
\hline $102 \mathrm{AP}=$ & 1107 & 0 & $\mathrm{CP}$ & 33 \\
\hline $103 A P=$ & 1133 & 0 & DN & 7 \\
\hline $104 \mathrm{AP}=$ & 19 & 0 & DN & 1121 \\
\hline $105 \mathrm{AP}=$ & 821 & 0 & DSSF & 319 \\
\hline $106 \mathrm{AP}=$ & 1129 & 0 & DN & 11 \\
\hline $107 \mathrm{AP}=$ & 1115 & 0 & DN & 25 \\
\hline $108 \mathrm{AP}=$ & 902 & 0 & DN & 238 \\
\hline TOTAL $=$ & 25424 & & TOTAL & 5856 \\
\hline
\end{tabular}

\begin{tabular}{|lr|}
\hline SEGREGATED SPACE \\
101AW $=$ & -11 \\
$103 A W=$ & 495 \\
$102 A P=$ & 33 \\
$105 A P=$ & 319 \\
$101 S Y=$ & 31 \\
$103 S Y=$ & 385 \\
$101 A Y=$ & 72 \\
102AN $=$ & 39 \\
103AN $=$ & 189 \\
104AN $=$ & 76 \\
105AN $=$ & 11 \\
107AN $=$ & 72 \\
\hline TOTAL $=$ & 1711 \\
WATCHLIST TANKS \\
\hline PRIOIITY SPACE \\
102SY $=$ & 411 \\
101AN $=$ & 500 \\
102AW $=$ & 254 \\
106AW $=$ & 66 \\
\hline TOTAL $=$ & 1231 \\
\hline
\end{tabular}

\begin{tabular}{|lc|}
\hline MISC. HEADSTACE \\
101AP $=$ & 79 \\
103AP $=$ & 7 \\
106AP $=$ & 11 \\
107AP $=$ & 25 \\
104AW $=$ & 16 \\
101AZ $=$ & 11 \\
102AZ $=$ & 20 \\
\hline TOTAL $=$ & 169 \\
\hline
\end{tabular}

Inventory Calculation by Waste Type:

\begin{tabular}{|c|c|c|c|}
\hline COM & CON & ENTRATE & \\
\hline $102 \mathrm{AN}=$ & 1101 & (CC) & \\
\hline $107 \mathrm{AN}=$ & 1068 & (CC) & \\
\hline $101 S Y=$ & 1109 & (CC \& DSS & \\
\hline $103 S Y=$ & 755 & (CC, DSS & SWL) \\
\hline $101 \mathrm{AY}=$ & 908 & (DC) & \\
\hline TOTAL $=$ & 4941 & & \\
\hline & NCAT & & \\
\hline $103 \mathrm{AW}=$ & 158 & SOLJDS= & 487 \\
\hline $105 \mathrm{AW}=$ & 614 & SOLDS = & 388 \\
\hline TOTAL $=$ & 772 & TOTAL $=$ & 875 \\
\hline
\end{tabular}

\begin{tabular}{|c|c|c|c|}
\hline \multicolumn{4}{|c|}{ WEST AREA WASTE (DN/PD) } \\
\hline $102 S Y=$ & 596 & SOLIDS $=$ & 133 \\
\hline 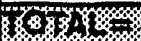 & 50 & 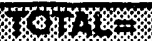 & 8 \\
\hline
\end{tabular}

\begin{tabular}{|c|c|}
\hline $\begin{array}{l}106 \mathrm{AN}= \\
102 \mathrm{AP}=\end{array}$ & $\begin{array}{l}\text { PHOSTPHATE (CP) } \\
23 \\
1107\end{array}$ \\
\hline $8 \% 5$ & $1 \mathrm{con}$ \\
\hline
\end{tabular}

\begin{tabular}{|c|c|}
\hline \multicolumn{2}{|c|}{ DILUTE WASTE (DN) } \\
\hline $101 \mathrm{AP}=$ & 1061 \\
\hline $103 \mathrm{AP}=$ & 1133 \\
\hline 106AP $=$ & 1129 \\
\hline $107 A P=$ & 1115 \\
\hline $108 A P=$ & 902 \\
\hline $101 \mathrm{AN}=$ & 640 \\
\hline $102 \mathrm{AW}=$ & 886 \\
\hline $104 \mathrm{AW}=$ & 1124 \\
\hline $106 \mathrm{AW}=$ & 1074 \\
\hline $102 A Y=$ & 849 \\
\hline $104 A P=$ & 19 \\
\hline $8 \%$ & $20^{\circ}$ \\
\hline $\begin{array}{r}\text { NCAW } \\
\text { (@ }\end{array}$ & $\begin{array}{l}\text { IINGWAS } \\
\text { ( Na) }\end{array}$ \\
\hline $101 A Z=$ & 791 \\
\hline $102 A Z=$ & 434. \\
\hline $88 \%$ & 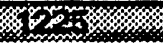 \\
\hline$D N=$ & 704 \\
\hline
\end{tabular}

\begin{tabular}{||rr|}
\hline USEABLE SPACE \\
& \\
104AP $=$ & 1121 \\
108AP $=$ & 238 \\
105AW $=$ & 138 \\
102AY $=$ & 131 \\
106AN $=$ & 1117 \\
\hline TOTAL $=$ & 2745 \\
SPARES & -2280 \\
\hline USEABLE & 465 \\
\hline
\end{tabular}

TOTAL SPACE AVAILABLE NON-AGING 27360 AGING =

TOTAL $=\quad 31280$

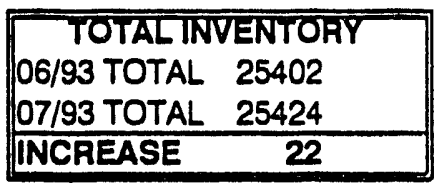

\begin{tabular}{|lc|}
\hline USEABLE SPACE \\
\hline O6/93 TOTAL & 517 \\
O7/93 TOTAL & 465 \\
\hline DEPLETION & -52 \\
\hline
\end{tabular}

\begin{tabular}{|lc|}
\hline PRIOAITY SPACE \\
\hline O6/93 TOTAL & 1245 \\
O7/93 TOTAL & 1231 \\
\hline DEPLETION & -14 \\
\hline
\end{tabular}

NOTE: Depletion in "Usable" tank space partially due to Tank 102-AP being moved to "Segregated" space NOTE: All Values are in Kilogallons. 
Table B-2. Double Shell Tank Waste Inventory for July 31, $1993 \quad$ (page 2 of 2)

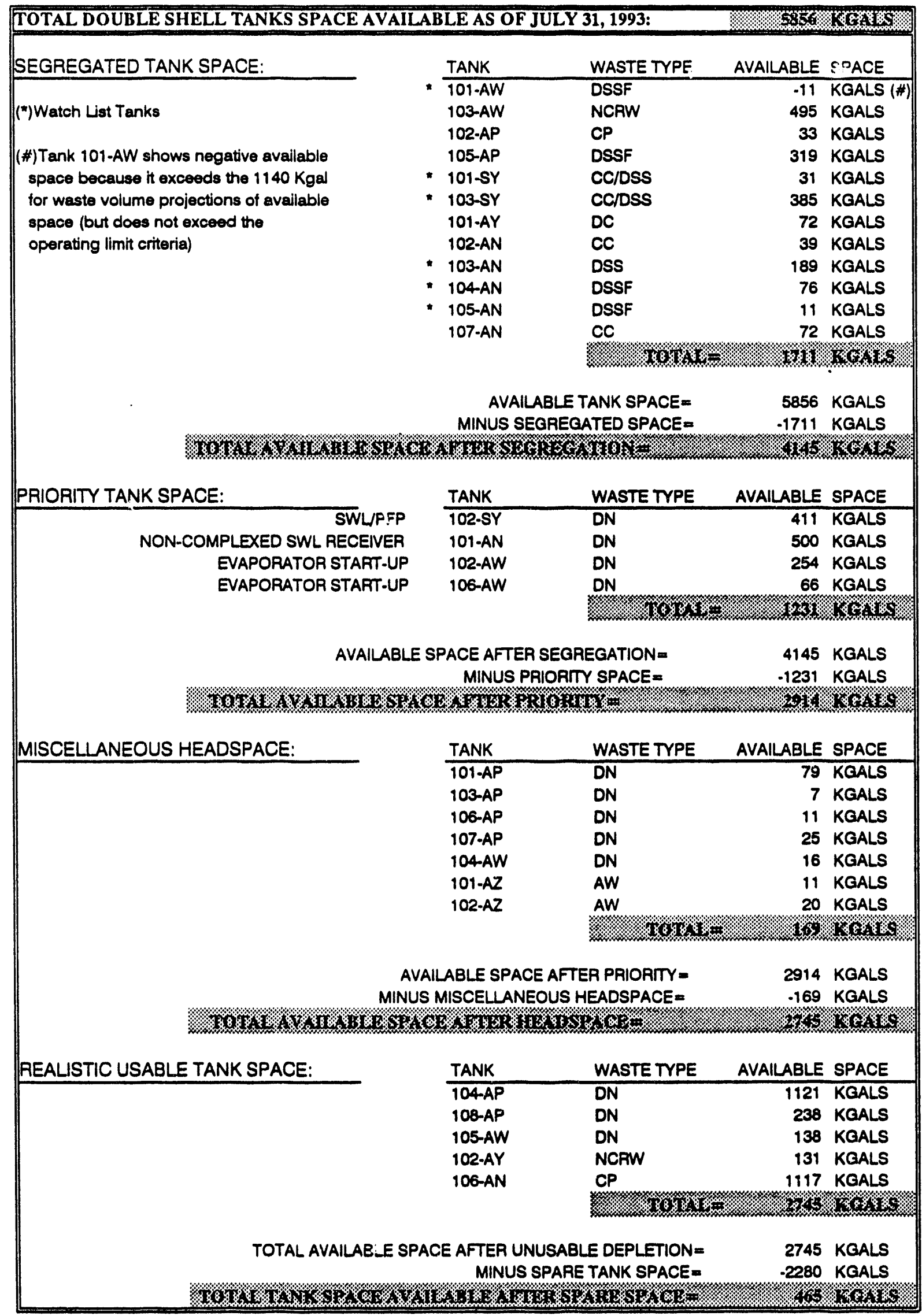


WHC-EP-0182-64

\section{APPENDIX C}

TANK AND EQUIPMENT CODE AND STATUS DEFINITIONS 


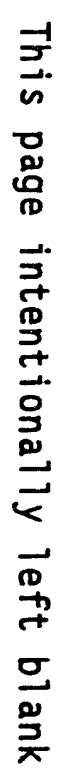

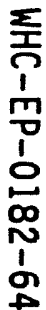




\section{TANK AND EQUIPMENT CODE/STATUS DEFINITIONS \\ July 1993}

\section{TANK STATUS CODES}

\section{WASTE TYPE}

$\begin{array}{ll}\text { AGING } & \text { Aging Waste (Neutralized Current Acid Waste [NCAW]) } \\ \text { CC } & \text { Complexant Concentrate Waste } \\ \text { CP } & \text { Concentrated Phosphate Waste } \\ \text { DC } & \text { Dilute Complexed Waste } \\ \text { DN } & \text { Dilute Non-Complexed Waste } \\ \text { DSS } & \text { Double-Shell Slurry } \\ \text { DSSF } & \text { Double-Shell Slurry Feed } \\ \text { NCPLX } & \text { Non-Complexed Waste } \\ \text { PD/PN } & \text { Plutonium-Uranium Extraction (PUREX) Neutralized Cladding } \\ & \text { Removal Waste (NCRW), transuranic waste (TRU) } \\ \text { PT } & \text { Plutonium Finishing Plant (PFP) TRU Solids }\end{array}$

\section{TANK USE (DOUBLE-SHELL TANKS ONLY)}

$\begin{array}{ll}\text { CWHT } & \text { Concentrated Waste Holding Tank } \\ \text { DRCVR } & \text { Dilute Receiver Tank } \\ \text { EVFD } & \text { Evaporate Feed Tank } \\ \text { GRTFD } & \text { Grout Feed Tank } \\ \text { SRCVR } & \text { Slurry Receiver Tank }\end{array}$

2. SOLID AND LIQUID VOLUME DETERMINATION METHODS

$\begin{array}{ll}\text { F } & \text { Food Instrument Company (FIC) Automatic Surface Level Gauge } \\ M & \text { Manual Tape Surface Level Gauge } \\ \text { P } & \text { Photo Evaluation } \\ S & \text { Sludge Level Measurement Device }\end{array}$

\section{DEFINITIONS}

\section{WASTE TANKS - GENERAL}

Waste Tank

Safety Issue

Watch List Tank
A potentially unsafe condition in the handling of waste material in underground storage tanks that requires corrective action to reduce or el iminate the unsafe condition.

An underground storage tank containing waste that requires special safety precautions because it may have a serious potential for release of high level radioactive waste because of uncontrolled increases in temperature or pressure. Special restrictions have been placed on these tanks by "Safety Measures for Waste Tanks at Hanford Nuclear Reservation, " Section 3137 of the National Defense Authorization Act for Fiscal Year 1991, November 5, 1990, Public Law 101-510, (a) so known as the Wyden Amendment). 


\section{WASTE TYPES}

Aging Waste

(AGING)

Concentrated

Complexant (CC)

Concentrated

Phosphate Waste

$(C P)$

Dilute Complexed Waste (DC)
High level, first cycle solvent extraction waste from the PUREX plant (NCAW)

Concentrated product from the evaporation of dilute complexed waste.

Waste originating from the decontamination of $100 \mathrm{~N}$ Area reactor. Concentration of this waste produces concentrated phosphate waste.

Characterized by a high content of organic carbon including organic complexants:

ethylenediaminetetra-acetic acid (EDTA), citric acid, hydroxyethyl-ethylenediaminetriacetic acid (HEDTA), and iminodiacetate (IDA) being the major complexants used. Main sources of DC waste in the DST system are saltwell liquid inventory.

Dilute Non-Complexed Waste (DN)

Low activity liquid waste originating from $T$ and $S$ Plants, the 300 and 400 Areas, PUREX facility (decladding supernatant and miscellaneous wastes), $100 \mathrm{~N}$ Area (sulfate waste), B Plant, saltwells, and PFP (supernate).

Double-Shell Slurry (DSS)

Double-Shell Slurry Feed (DSSF)

Non-complexed (NCPLX)

PUREX Decladding $(P D / P N)$

PFP TRU Solids (PT)

Drainable Interstitial Liquid (DIL)
Waste that exceeds the sodium aluminate saturation boundary in the evaporator without exceeding receiver tank composition limits. For reporting purposes, DSS is considered a solid.

Waste concentrated just before reaching the sodium aluminate saturation boundary in the evaporator without exceeding receiver tank composition limits. This form is not as concentrated as DSS.

General waste term applied to all Hanford site liquors not identified as complexed.

PUREX Neutralized Cladding Removal Waste (NCRW) is the solids portion of the PUREX plant neutralized cladding removal waste stream; received in Tank Farms as a slurry. NCRW solids are classified as transuranic (TRU) waste.

TRU solids fraction from PFP PIant operations.

Interstitial liquid that is not held in place by capillary forces, and will therefore migrate or move by gravity. 
Supernate

Ferrocyanide

WASTE STATUS

In-Service Tank

Out-of-Service

Tank
The liquid above the solids in waste storage tanks.

A compound of iron and cyanide commonly expressed as $\mathrm{FeCN}$. The actual formula for the ferrocyanide anion is $\left[\mathrm{Fe}(\mathrm{CN})_{6}\right]^{-4}$.

The waste classification of a tank being used, or planned for use, for the storage of liquid (in excess of a minimum supernatant liquid heel) in conjunction with production and/or waste processing.

A tank which does not meet the definition of an inservice tank. Before September 1988, these tanks were defined as inactive in this report. [Note: All single-shell tanks (SST) are out of service.]

\section{STABILIZATION (Single-Shell Tanks only)}

Interim

Stabilized

(IS)
A tank which contains less than 50,000 gal of drainable interstitial liquid and less than 5,000 gal of supernatant liquid. If the tank was jet pumped to achieve interim stabilization, then the jet pump flow must al so have been at or below $0.05 \mathrm{gpm}$ before interim stabilization criteria is met.

\section{INTRUSION PREVENTION (ISOLATION) Single-Shell Tanks only}

Partially

Interim Isolated (PI)

Interim Isolated (II)

Intrusion

Prevention (IP)
The administrative designation reflecting the completion of the physical effort required for Interim Isolation except for isolation of risers and piping that is required for jet pumping or for other methods of stabilization.

The administrative designation reflecting the completion of the physical effort required to minimize the addition of liquids into an inactive storage tank, process vault, sump, catch tank, or diversion box. In June 1993, Interim Isolation was replaced by Intrusion Prevention.

Intrusion Prevention is the administrative designation reflecting the completion of the physical effort required to minimize the addition of liquids into an inactive storage tank, process vault, sump, catch tank, or diversion box. Under no circumstances are electrical or instrumentation devices disconnected or disabled during the intrusion preventation process (with the exception of the electrical pump), in accordance with WHC-SDWM-SAR-006 REV 2, Single-Shell Tank Isolation Safety Analysis Report, March 1986. 
IANK INTEGRITY

Sound

Assumed Leaker

Assumed Re-Leaker

Intrusion

\section{TANK INVESTIGATION}

The integrity classification of a waste storage tank for which surveillance data indicate no loss of liquid attributed to a breach of integrity.

The integrity classification of a waste storage tank for which surveillance data indicate a loss of liquid attributed to a breach of integrity.

A condition that exists after a tank has been declared as an "assumed leaker" and then the surveillance data indicates a new loss of liquid attributed to a breach of integrity.

A term used to describe the infiltration of liquid into a waste tank.

\section{SURVEILLANCE INSTRUMENTATION}

Drywells

Drywells are vertical boreholes with 6-in. (internal diameter) carbon steel casings positioned radially around SSTs. Periodic monitoring is done by gamma radiation or neutron sensors to obtain scan profiles of radiation or moisture in the soil as a function of well depth, which could be indicative of tank leakage. These wells range between 50 and $250 \mathrm{ft}$ in depth, and are monitored between the range of 50 to $150 \mathrm{ft}$. The wells are sealed when not in use. They are called drywells because they do not penetrate to the water table and are therefore usually "dry." The drywell frequency monitoring schedule calls for 105 drywells weekly, 91 biweekly, 41 monthly, 151 quarterly, and 371 annualiy.

Laterals

Laterals are horizontal drywells positioned under single-shell waste storage tanks to detect radionuclides in the soil which could be indicative of tank leakage. These drywells are monitored by radiation detection probes. Laterals are 4-in. inside diameter steel pipes located 8 to $10 \mathrm{ft}$ below the tank's concrete base. There are three laterals per tank. Laterals are located only in $A$ and $S X$ farms.

Surface Levels The surface level measurements in all waste storage tanks are monitored by manual or automatic conductivity probes, and recorded and transmitted or inputted to the Computer Automated Surveillance System (CASS). 
Automatic FIC

Annulus

Liquid Observa-

tion Well (LOW)

Thermocouple (TC)
An automatic waste surface level measurement device is manufactured by the Food Instrument Company (FIC). The instrument consists of a conductivity eiectrode (plummet) connected to a calibrated steel tape, a steel tape reel housing and a controller that automatically raises and lowers the plummet to obtain a waste surface level reading. The controller can provide a digital display of the data and also transmit the reading to the CASS. Some tanks have gauges connected to CASS and others are read manualiy.

The annulus is the space between the inner and outer shells on DSTs. Drain channels in the insulating and/or supporting concrete carry any leakage to the annulus space where conductivity probes are installed. Alarms from the annunciators are received by CASS. Continuous Air Monitoring (CAM) alarms are also located in the annulus. The annulus conductivity probes and radiation detectors are the primary means of leak detection for all DSTs.

In-tank liquid observation wells are used for monitoring the interstitial liquid level (ILL) in single-shell waste storage tanks. The wells are constructed of fiberglass or TEFZEL*-reinforced epoxy-polyester resin, sized to extend to within 1 in. of the bottom of the tank steel liner. They are sealed at their bottom ends and have a nominal outside diameter of $3.5 \mathrm{in}$. Two probes are used to monitor changes in the ILL: gamma and neutron, which can indicate intrusions or leakage by increases or decreases in the ILL. There are 58 LOWs (56 are in operation) installed in SSTs that contain or are capable of containing greater than 50,000 gal of drainable interstitial 1iquid, and in two DSTs only. The LOWs installed in two DSTs, (102-SY and 103-AW Tanks), are constructed of steel and are used for special surveillance purposes only.

A thermocouple is a thermoelectric device used to measure temperature. More than one thermocouple on a device (probe) is called a thermocouple tree. In DSTs there may be one or more thermocouple trees in risers in the primary tank. In addition, in DSTs only, there are thermocouple elements installed in the insulating concrete, the lower primary tank knuckle, the secondary tank concrete foundation, and in the outer structural concrete. These monitor temperature gradients within the concrete walls, installed in a riser, or lowered down an existing

*TEFZEL, a trademark of E. I. du Pont de Nemours \& Company 
In-tank

Photography bottom of the tank, and the domes. In SSTs, there may be one or more thermocouple trees instailed directly in a tank, although some SSTs do not have any trees installed. A single thermocouple may be

riser or LOW. There are also four thermocouple laterals beneath Tank 105-A in which temperature readings are taken in 34 thermocouples.

In-tank photographs may be taken to aid in resolving in-tank measurement anomalies and determine tank integrity. Photographs help determine sludge and liquid levels by visual examination.

4. INVENTORY AND STATUS BY TANK - COLUMN CALCULATIONS (SINGLE-SHELL TANKS)

\section{COLUMN HEADING}

Total Waste Solids Volume plus Supernatant liquid.

Supernatant Liquid

Drainable Interstitial

Total Jet

Pumped

Drainable

Liquid

Remaining

Pumpable

Liquid

Remaining

Sludge

Saltcake

Cumulative total pumped 1979 to date.

Supernate plus Drainable Interstitial. estimate the volume.
Drainable Liquid Remaining minus Drainable Interstitial. Supernate is usually derived by subtracting the solids level measurement from the liquid level measurement.

Drainable Liquid Remaining minus Supernate.

Drainable Interstitial Liquid is calculated based on the saltcake and sludge volumes, using average porosity values or actual data for each tank, when available.

Drainable Liquid Remaining less undrainable heel volume.

Solids formed during sodium hydroxide additions to waste. Sludge usually was in the form of suspended solids when the waste was originally received in the tank from the waste generator. In-tank photographs may be used to

Results from crystalization and precipitation after concentration of liquid waste, usually in an evaporator. If saltcake is layered over sludge, it is only possible to measure total solids volume. In-tank photographs may be used to estimate the saltcake volume. 
Solids Volume Indicates the latest update of any change in the solids Update volume.

Solids Update Indicates the source or basis of the latest solids Source - See volume update.

Footnote

Last Photo Date of latest in-tank photographs taken.

Date

Change Since Indicates any change made since the previous month. Last Monthly Explanation for the change follows the Inventory and Report Status by Tank section. 


\section{WHC-EP-0182-64}

This page intentionally left blank 
WHC-EP-0182-64

\section{APPENDIX D}

TANK FARM CONFIGURATION, STATUS, AND FACILITY CHARTS 
WHC-EP-0182-64

This page intentionally left blank. 


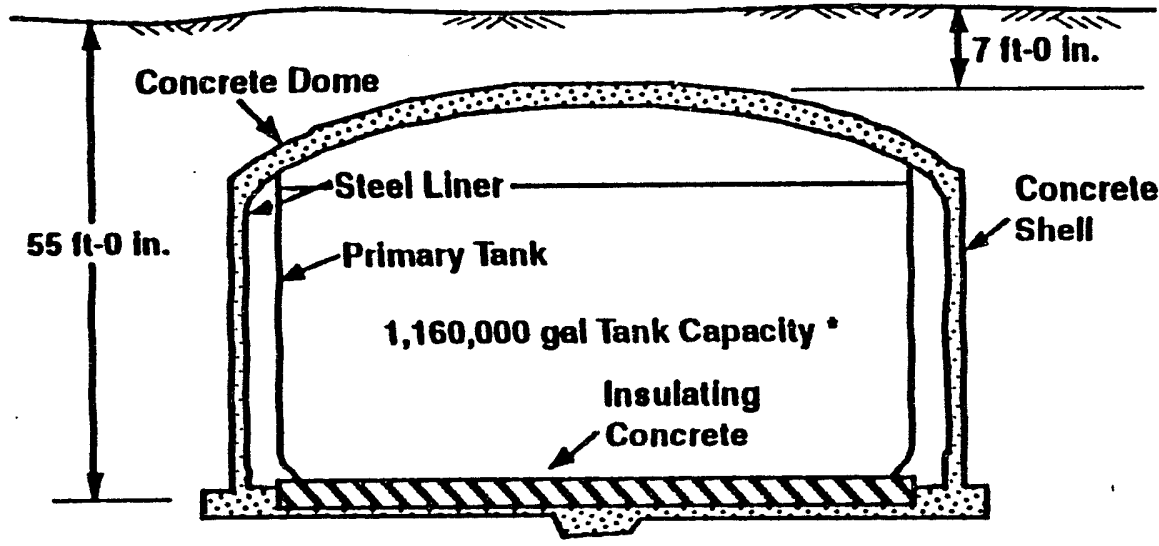

75 it Diameter Double-Shell Tank Tank Farms: AN, AP, AW, AY, AZ, SY

1

- AY and AZ Have a Tank Capacily of $1,000,000 \mathrm{gal}$

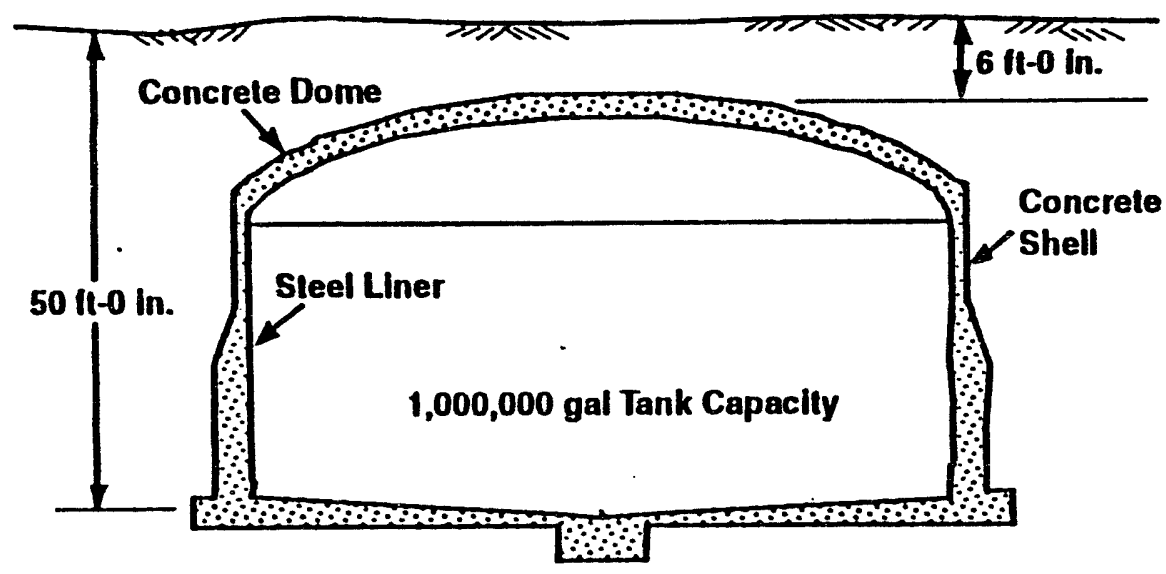

75 in Diameter Single-Shell Tank

Tank Farms: $A^{*}, A^{*}$, SX

- A and AX have Ilat boltoms

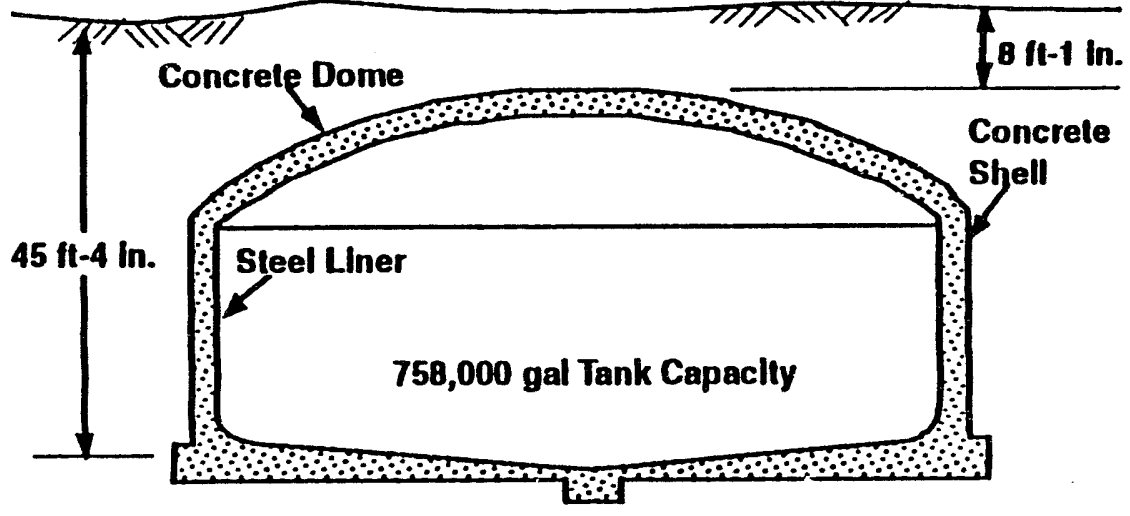

75 ft Dlameler Single-Shell Tank Tank Farms: BY, S, TX, TY
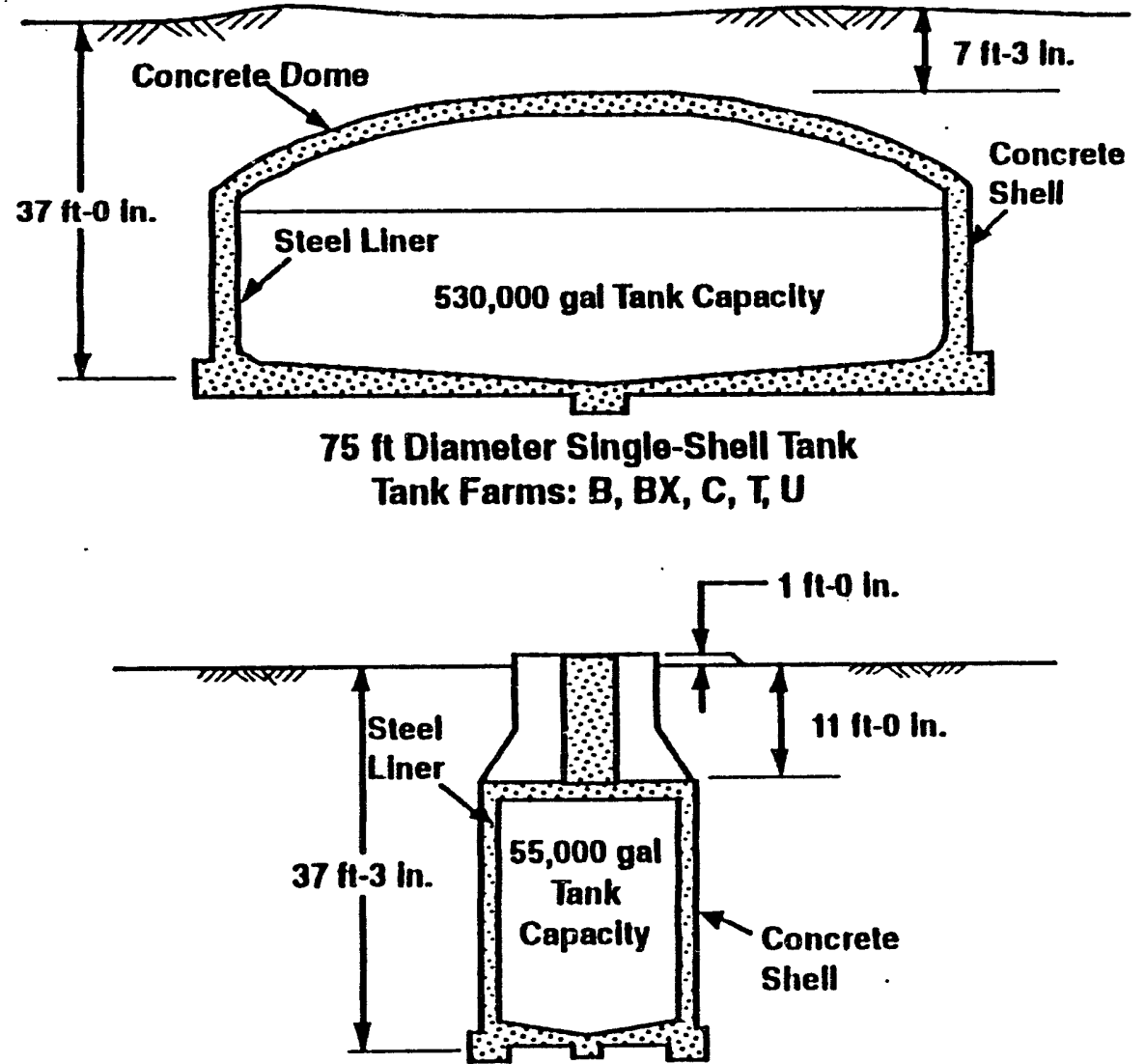

20 it Dlameler Single-Shell Tank Tank Farms: B, C, T, U

Figure D-1. High-Level Waste Tank Configuration 


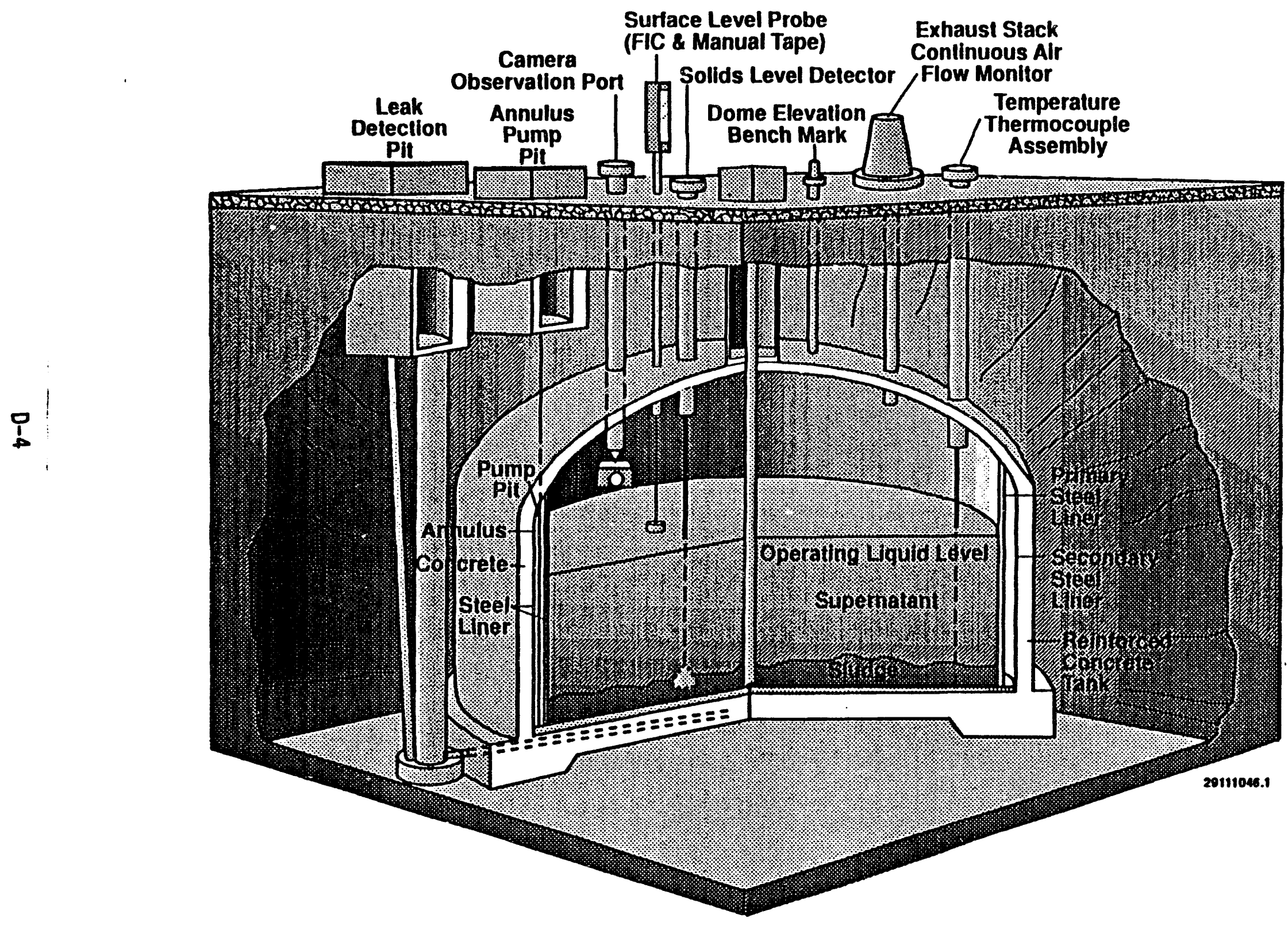

Figure D-2. Double-Shell Tank Instrumentation Configuration 


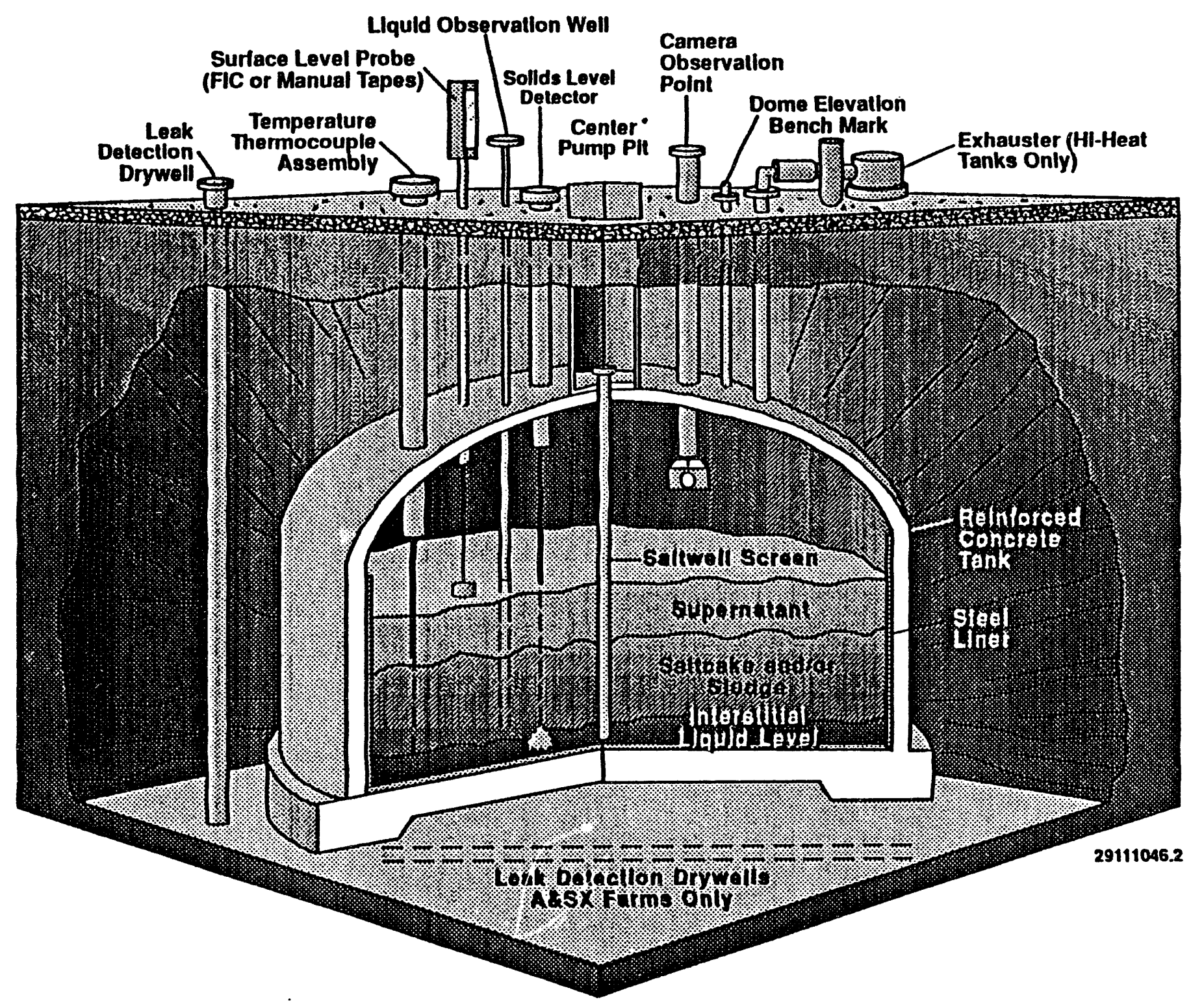

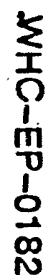

Figure D-3. Single-Shell Tank Instrumentation Configuration 
WHC-EP-0182-64

This page intentionally left blank

D-6 


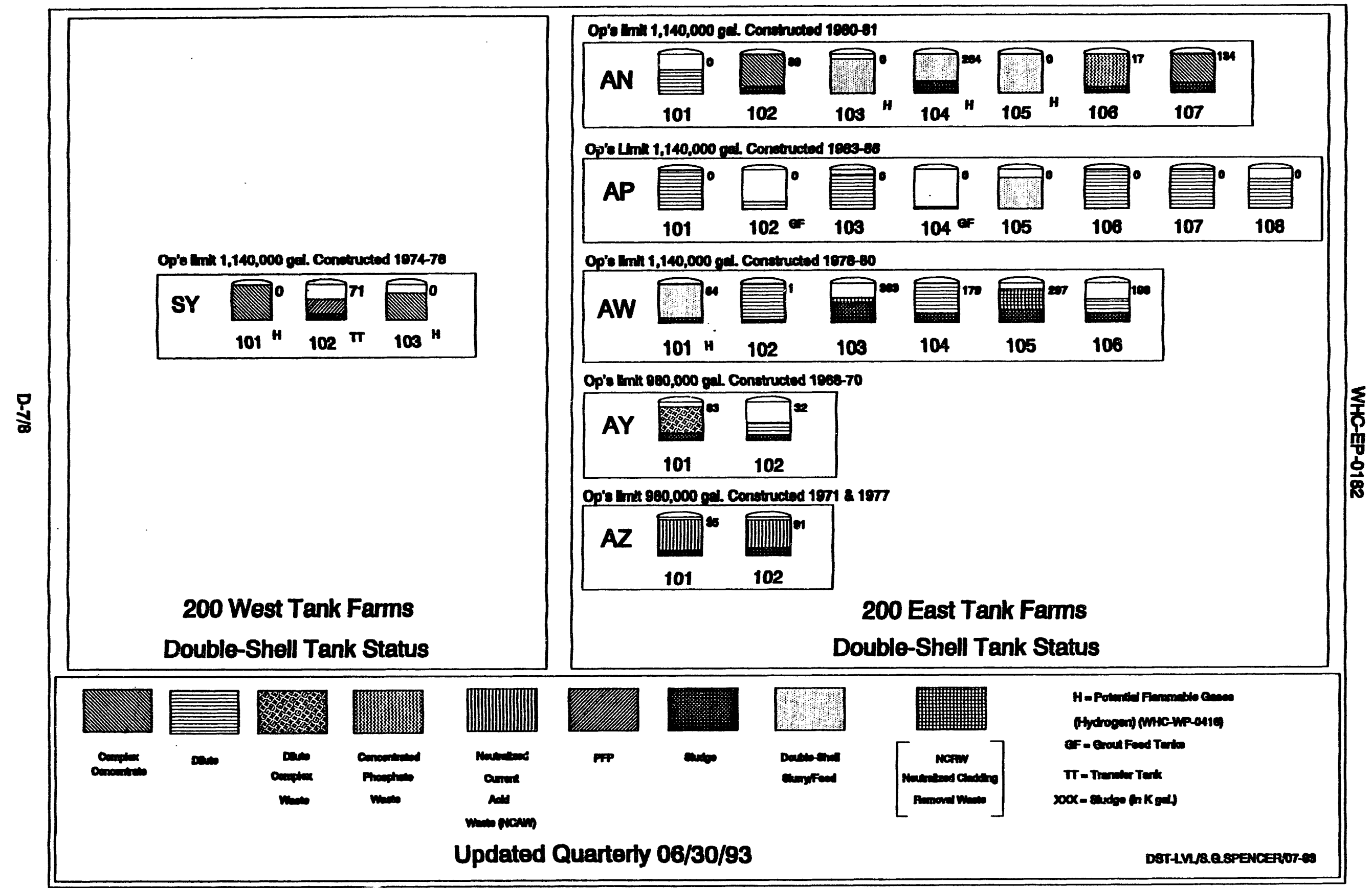

Flgure D-4. Doublo-Shell Tenk Status 
1,000,000 gal. tanlas Constructed 196456

A

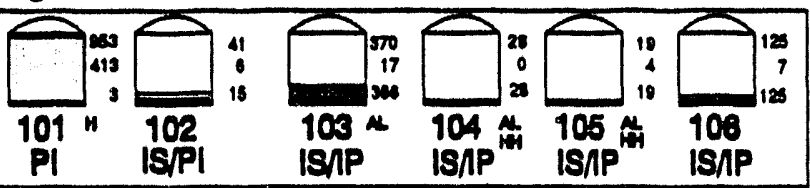

1,000,000 gal. tanka Conatructed 1900-64

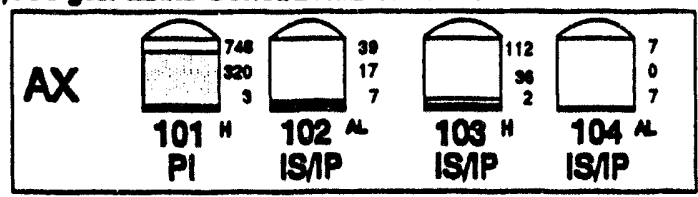

500,000 gal. tunle Conatructed $1949-44$

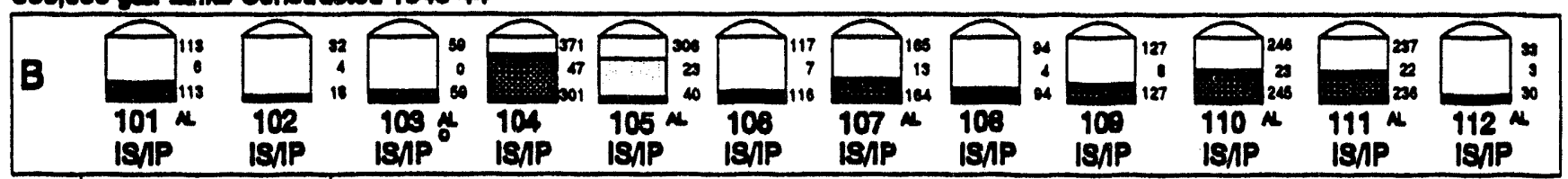

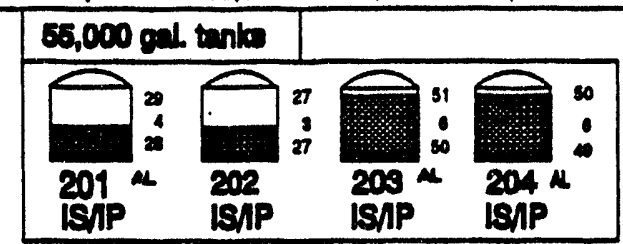

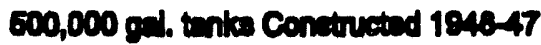

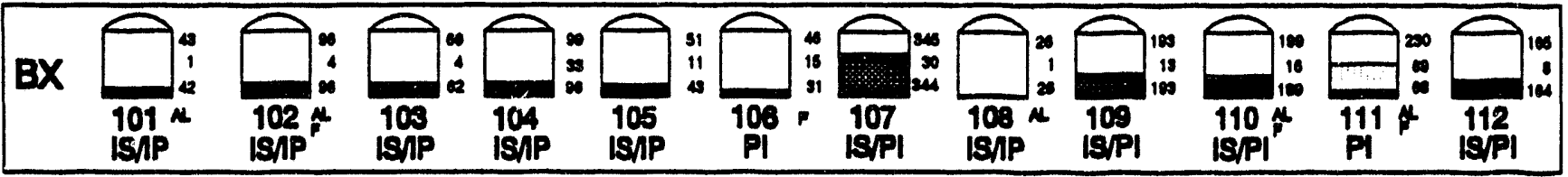

750,000 gal tanks Construeted 1948-40

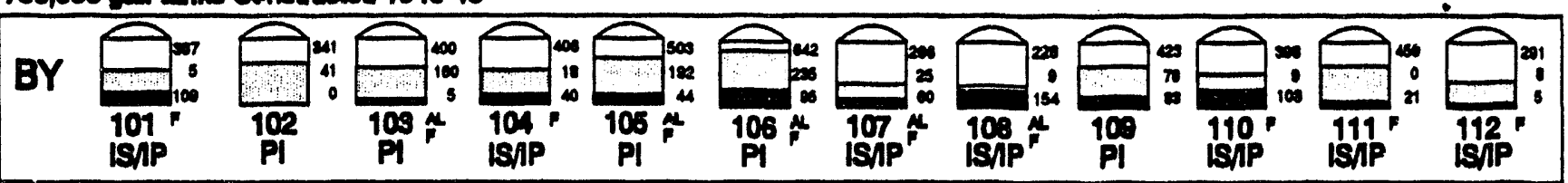

$000,000 \mathrm{gal}$ tanks Conotructed 1949-44

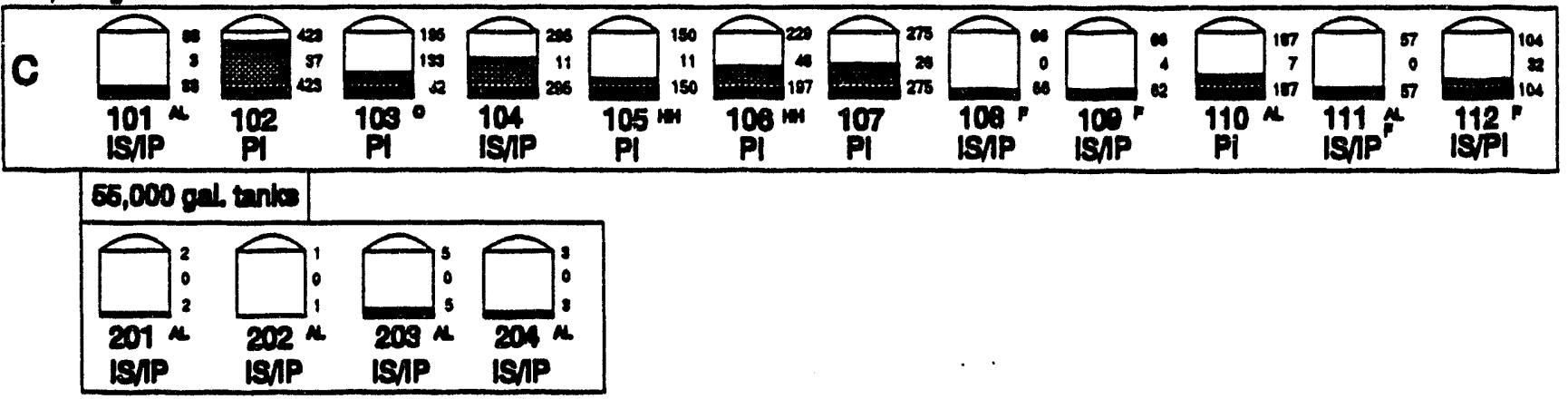

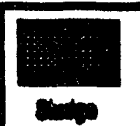

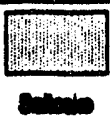

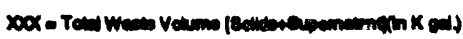

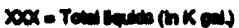

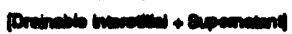

$x \times 0$ on (n)

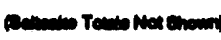

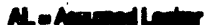

Molinumath

Fofruminato

minosim

O=0 Q

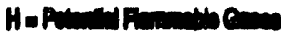

1.

Updated Quarterty 06/30/93
IP Antrualon Provention

is - Inturtin Stublleed

PI = Partally Intoritn leoleted

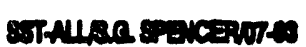

Figure D-5. 200E Single-Shell Tank Status 
760,000 gel. tanis Constructud 1830-61

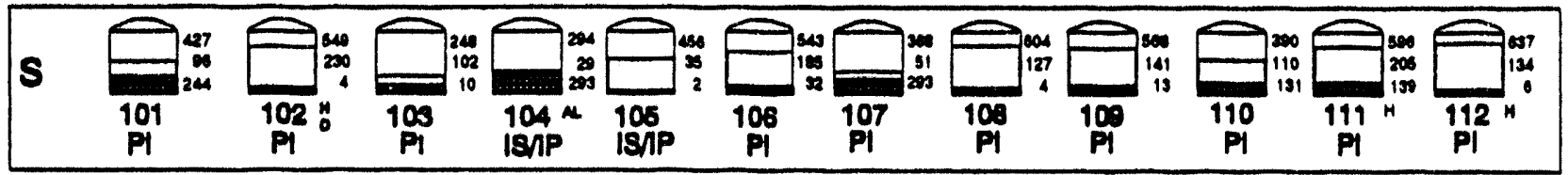

1,000,000 gel. tonice Conetructed 1963-54

$S X \sum_{101}^{101} \sum_{102}^{102}$

500,000 gal, tenks Constureted 1945-44

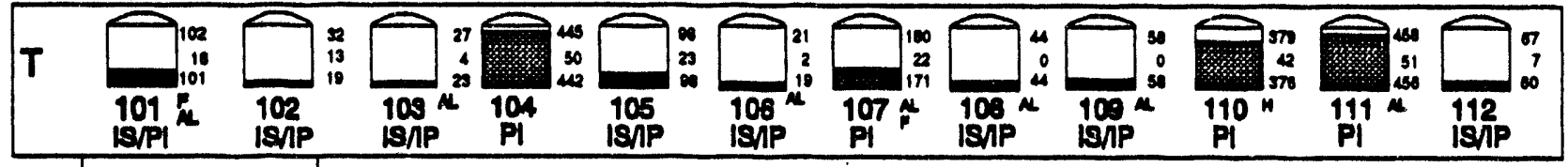

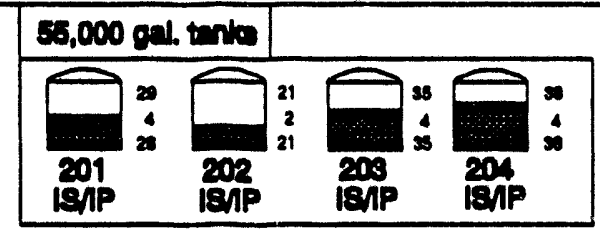

700,000 ged. tanke Conwucted 1047-48

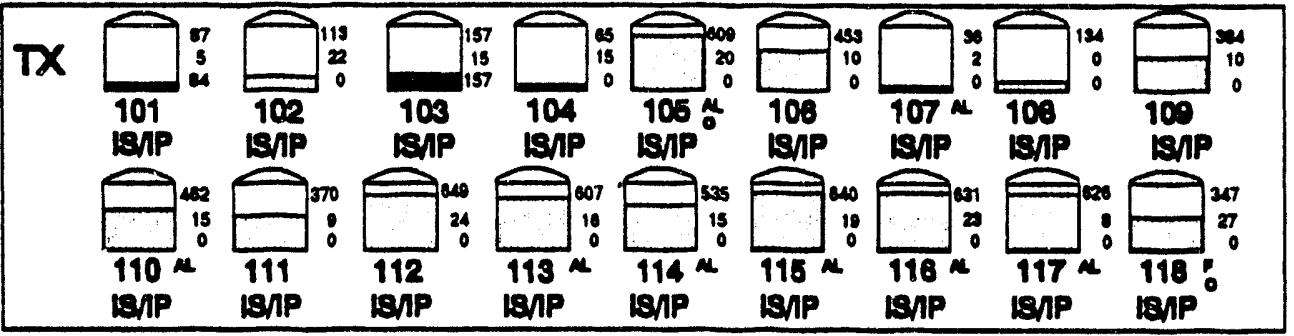

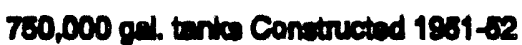

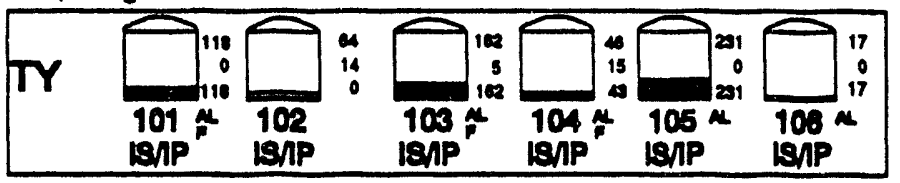

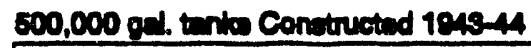

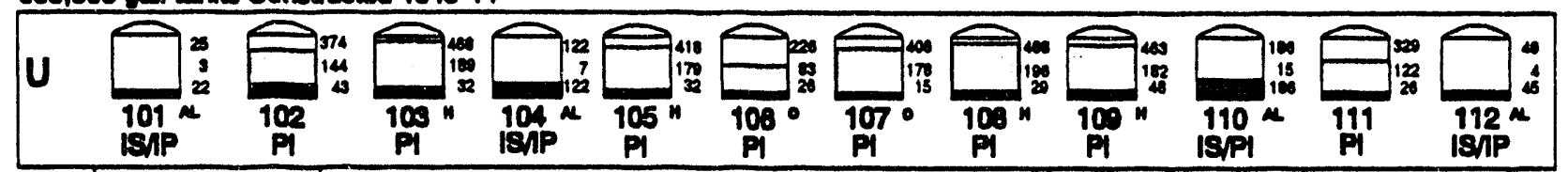

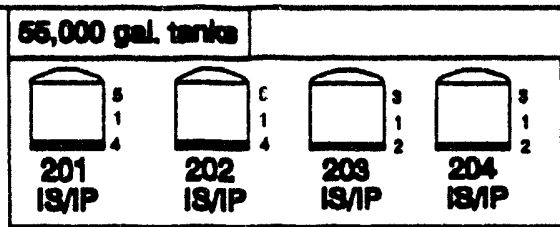

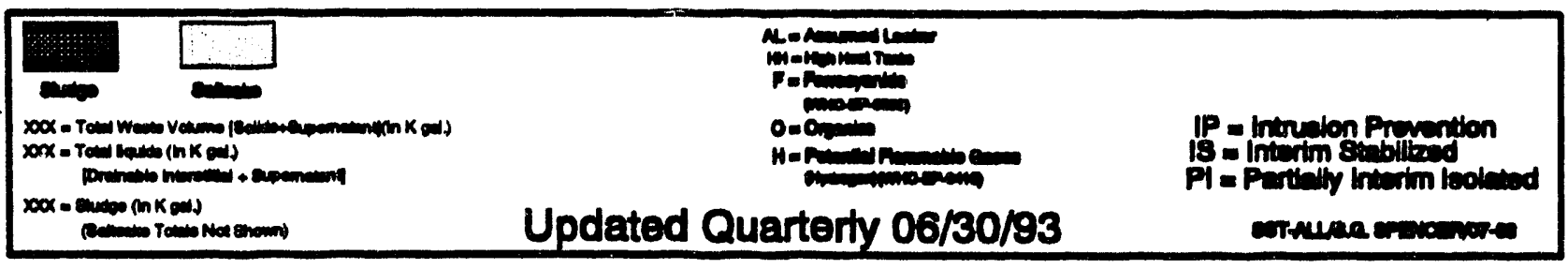

Fig. D-6. 200W Single-Shell Tank Status 


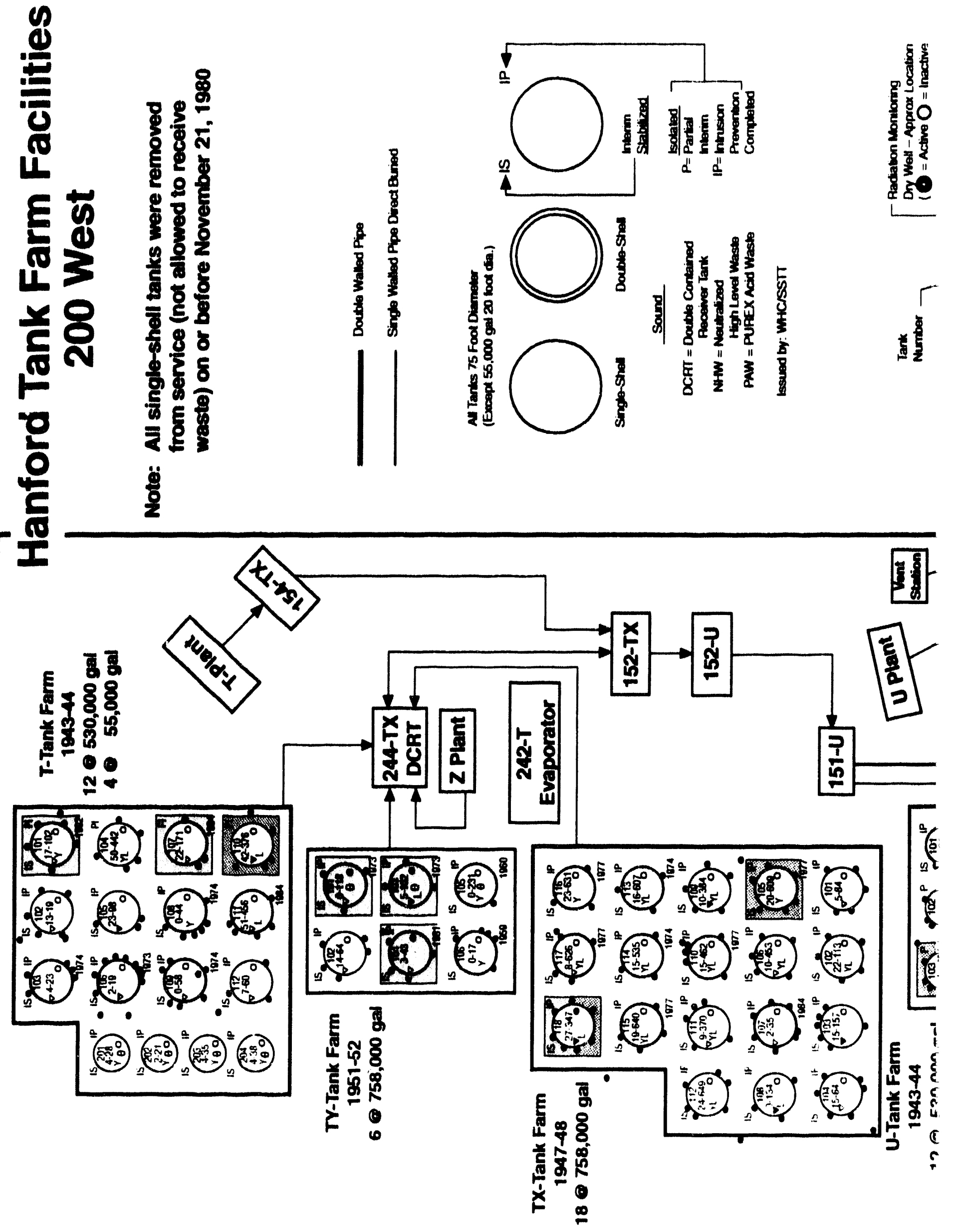




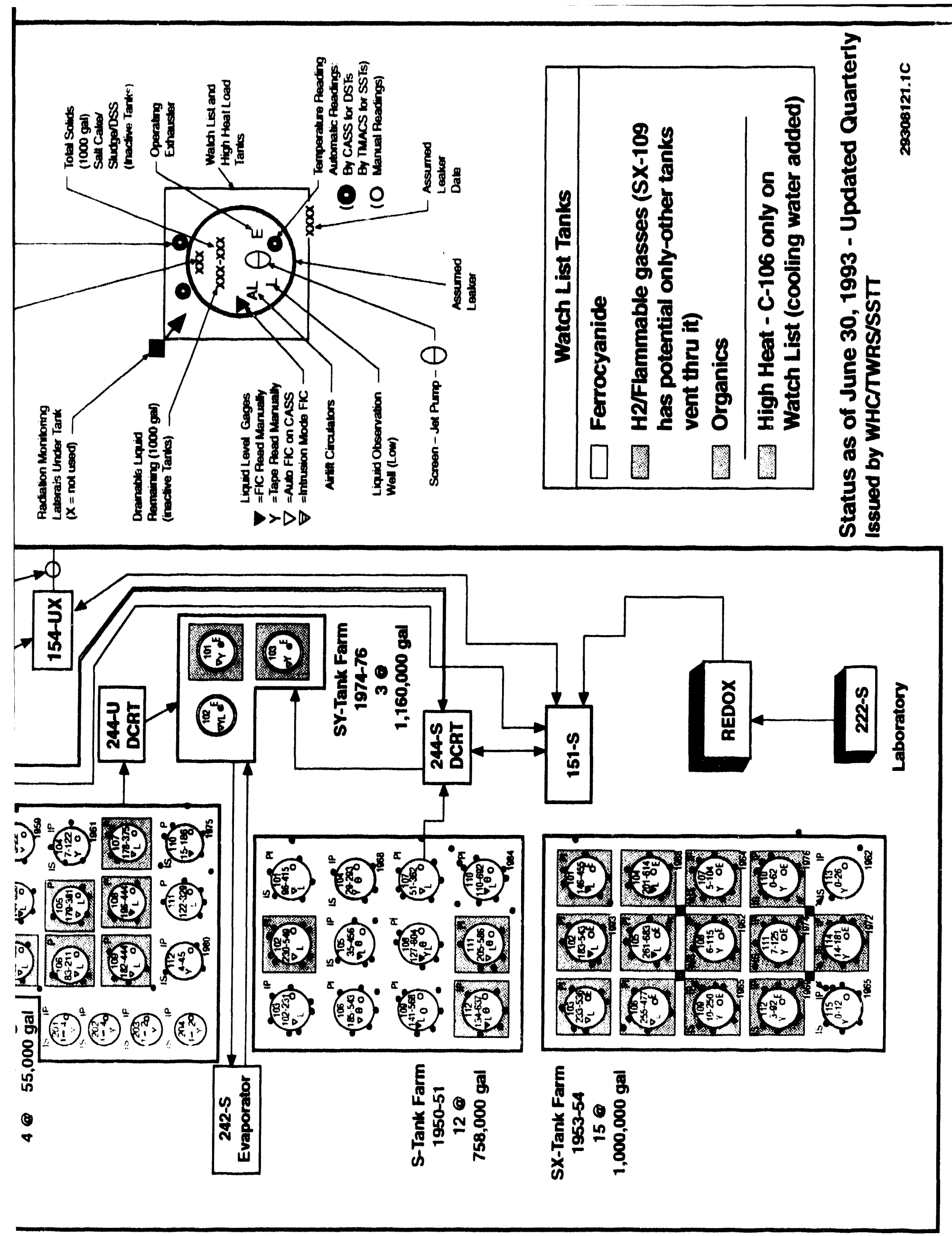




\section{East}

Hanford Tank Farm Facilities Br-Tank Famm

Note: All single-shell tanks were removed from senvice (not allowed to receive waste) on or before November 21, 1980

Single Walled Pipe Direct Buried

All Tanks 75 Foot Diameter

(Except 55.000 gal 20 foot dia.)
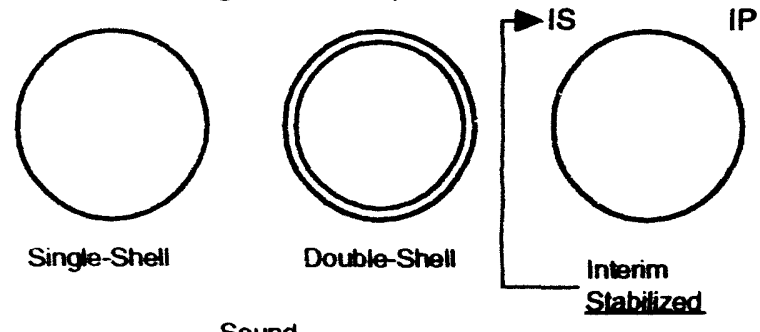

$$
\begin{array}{cc}
\text { Sound } \\
\text { DCRT }=\begin{array}{c}
\text { Double Contained } \\
\text { Receiver Tank }
\end{array} \\
\text { NHW }=\begin{array}{c}
\text { Neutralized } \\
\text { High Level Waste }
\end{array} \\
\text { PAW }=\text { PUREX Acid Waste }
\end{array}
$$

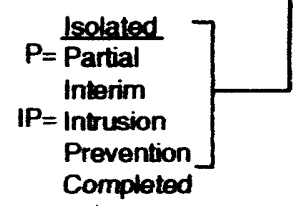

Issued by: WHC/SSTT

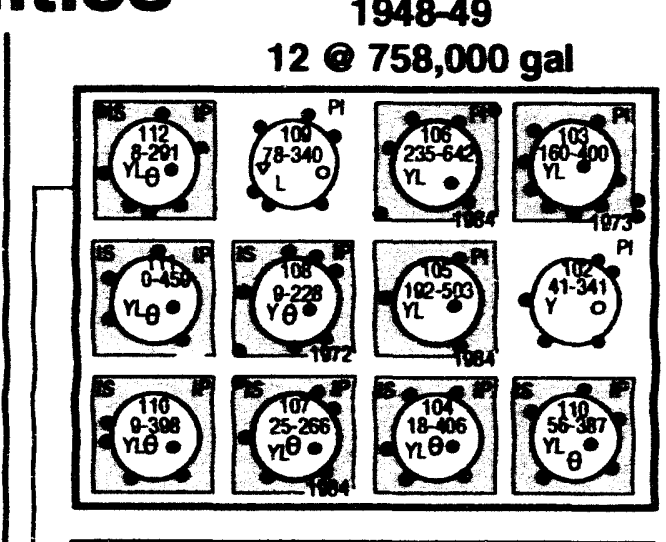

\section{B-Tank Farm}

1943-44

$12 \div 530,000 \mathrm{gal}$

4 (25,000 gal

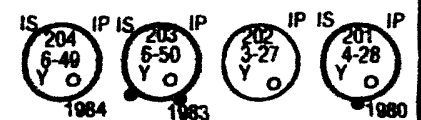

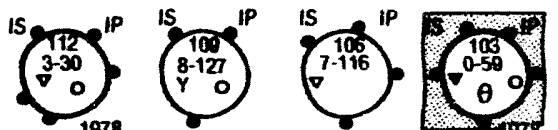

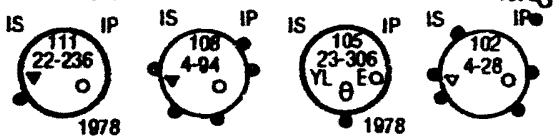
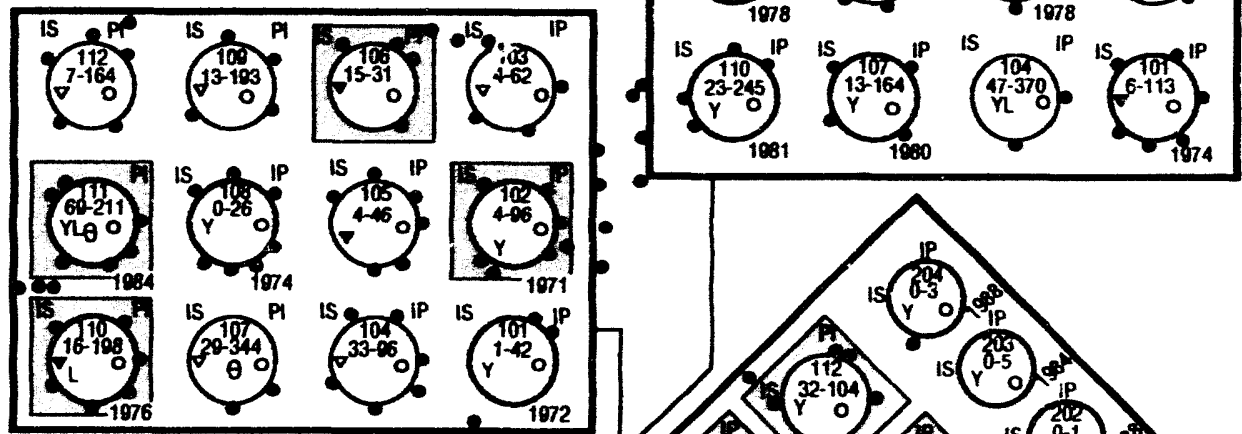

BX-Tank Farm

1946-47

$12 \times 530,000 \mathrm{gal}$

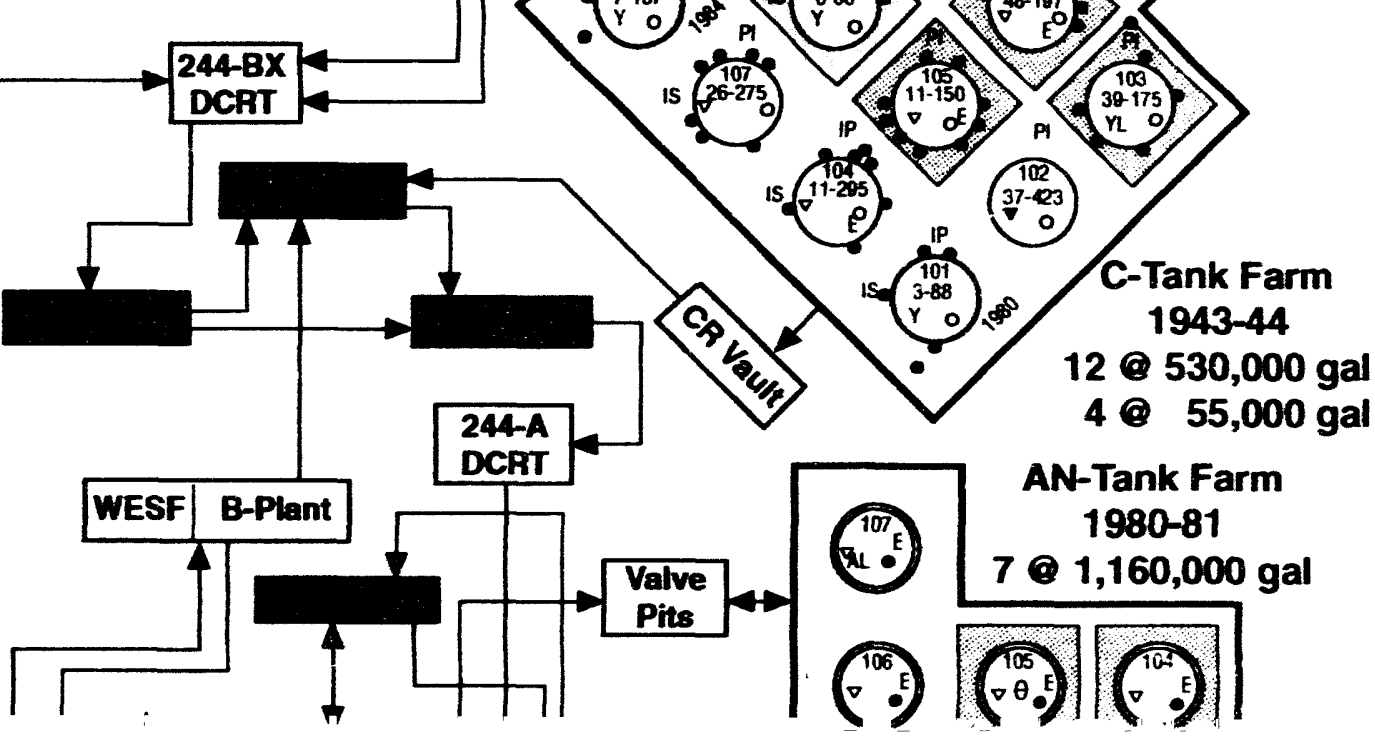




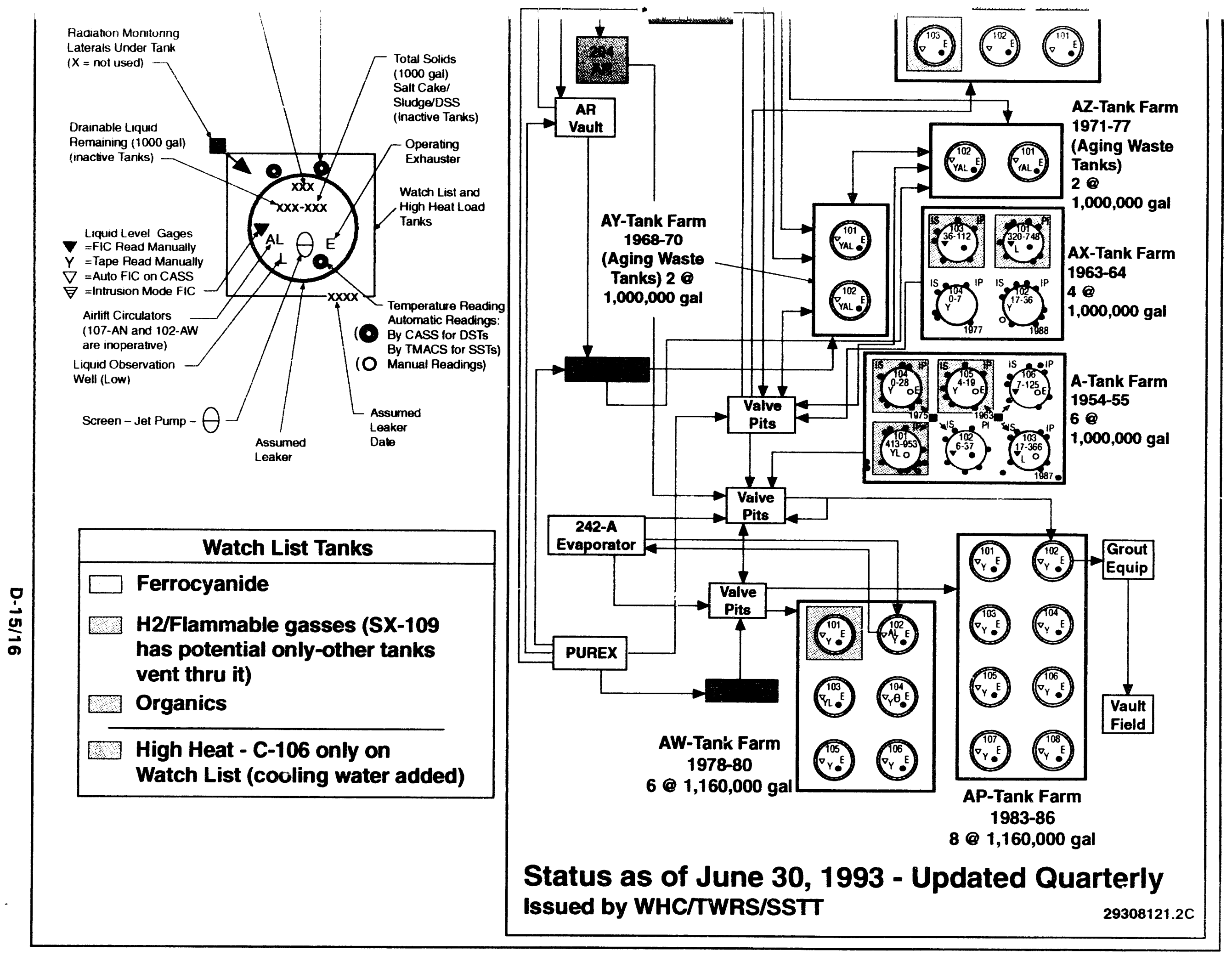


WHC-EP-0182-64

\title{
APPENDIX E
}

\author{
MONTHLY SUMMARY \\ TANK USE SUMMARY \\ INVENTORY SUMMARY BY TANK FARM \\ INVENTORY AND STATUS BY TANK
}


WHC-EP-0182-64

This page intentionally left blank.

$E-2$ 


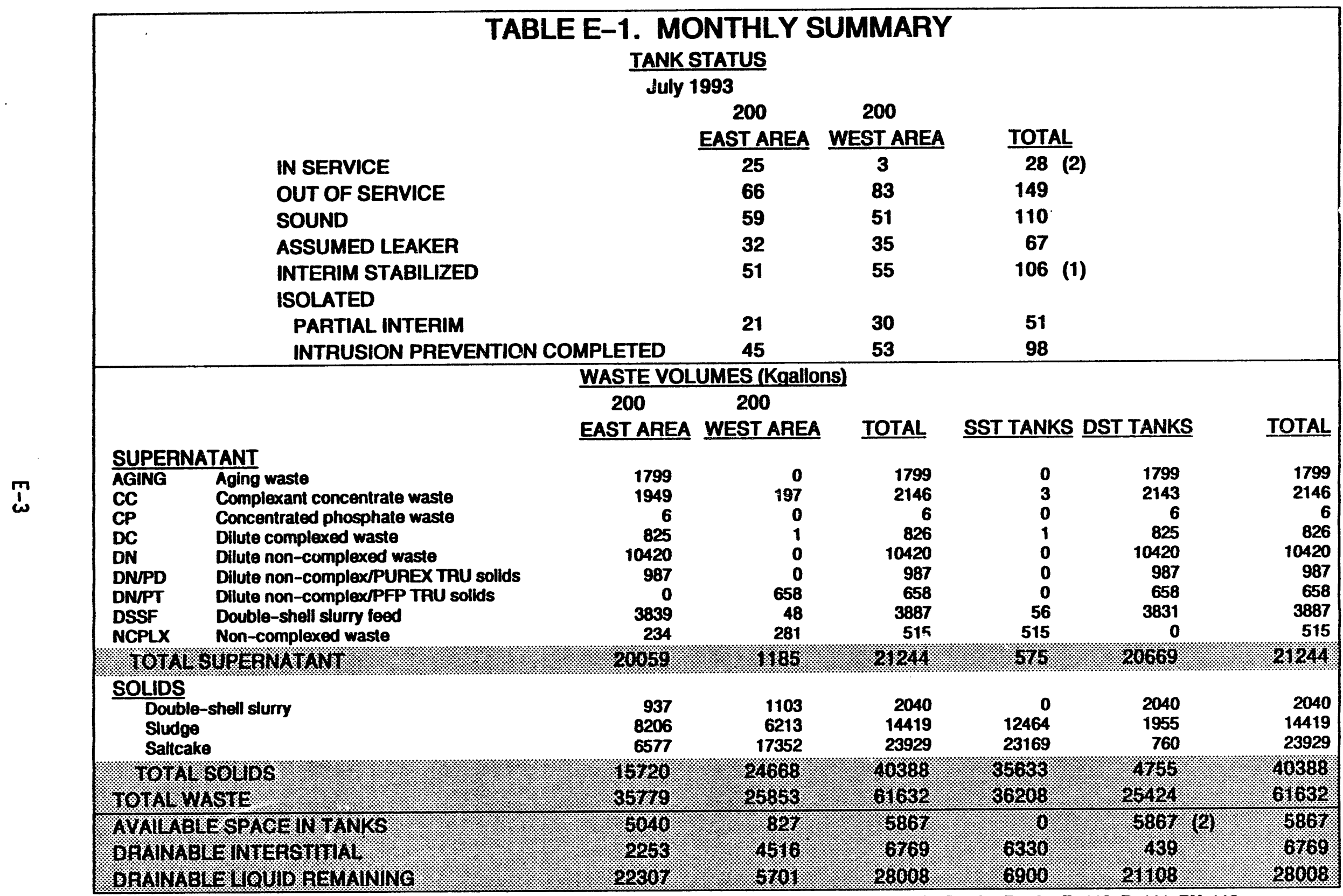

(1) Includes tanks that do not meet current established supernatant and interstitial liquid stabilization criteria, B-104, B-107, B-110, B-111, BX-110. $T-102, T-112$, and $U-110$.

(2) Includes six double-shell tanks on Hydrogen Watch List nol currently allowed to recelve waste, 103-AN, 104-AN, 105-AN, 101-AW, 101-SY, and 103-SY. Note: $+1-1$ Kgal differences are the result of computer rounding 
TABLE E-2. TANK USE SUMMARY

July 1993

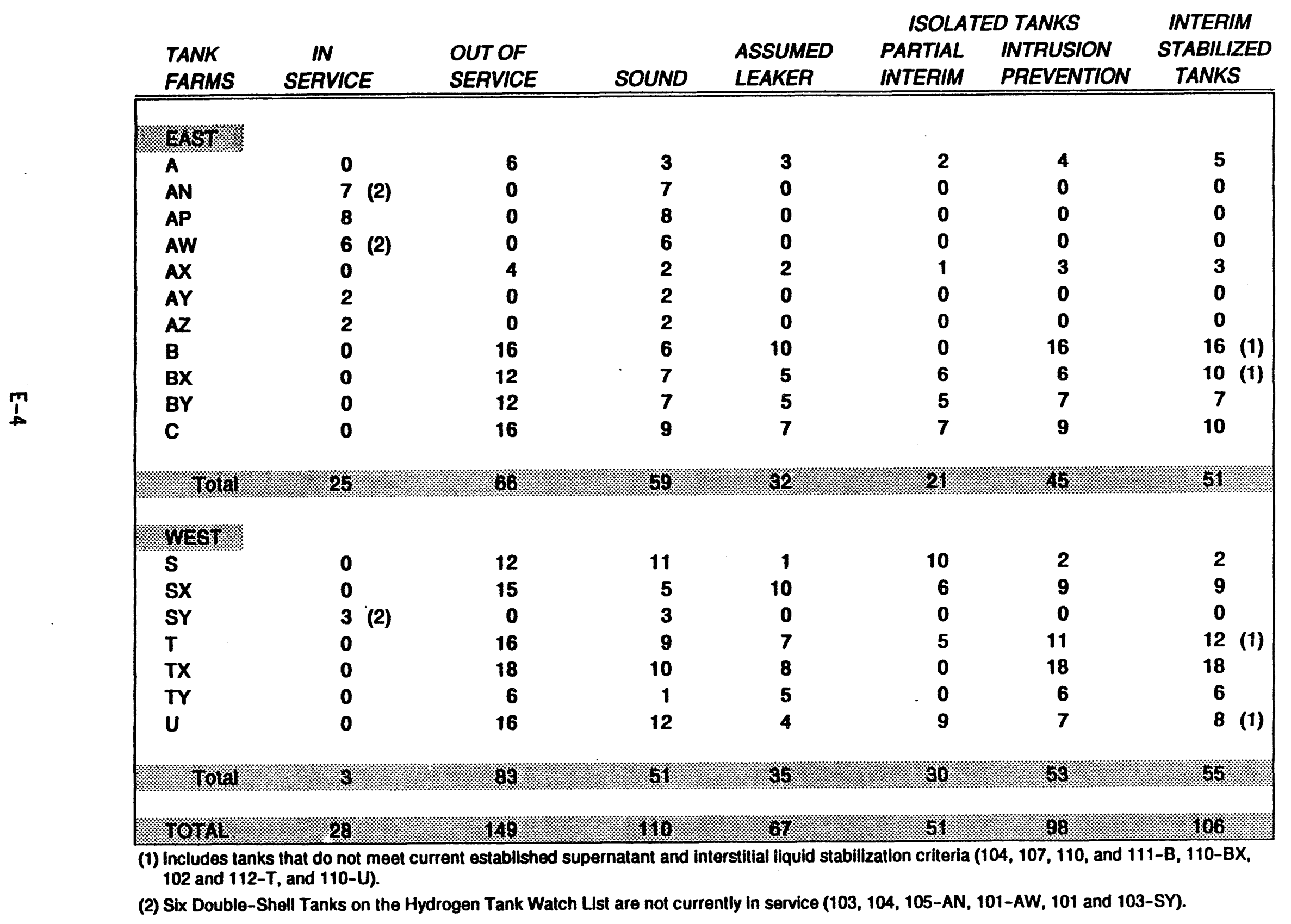


TABLE E-3. INVENTORY SUMMARY BY TANK FARM

WASTE VOLUMES (Kgallons)

July 1993

SUPERNATANT LIQUID VOLUMES

SOLIDS VOLUME

\begin{tabular}{|c|c|c|c|c|c|c|c|c|c|c|c|c|c|c|c|c|}
\hline $\begin{array}{l}\text { TANK } \\
\text { FARM }\end{array}$ & $\begin{array}{l}\text { TOTAL } \\
\text { WASTE }\end{array}$ & $\begin{array}{l}\text { AVAIL } \\
\text { SPACE }\end{array}$ & AGING & $\mathrm{CC}$ & CP & DC & DN & DN/PD & DN/PT & DSSF & NCPLX & TOTAL & DSS & SLUDGE & $\begin{array}{l}\text { SALT } \\
\text { CAKE }\end{array}$ & TOTAL \\
\hline$A N$ & 5976 & 2004 & 0 & 1946 & 6 & 0 & $\cdot 640$ & 0 & 0 & 1943 & $\mathbf{0}$ & 4535 & 937 & 504 & 0 & 1441 \\
\hline$A P$ & 7287 & 1833 & 0 & 0 & 0 & 0 & 6466 & 0 & 0 & 821 & 0 & 7287 & 0 & 0 & 0 & 0 \\
\hline AW & 5882 & 969 & 0 . & 0 & 0 & 0 & 2497 & 987 & $\mathbf{0}$ & 1067 & 0 & 4551 & 0 & 1135 & 196 & 1331 \\
\hline$A x$ & 906 & 0 & 0 & 3 & 0 & 0 & 0 & 0 & 0 & 0 & 0 & 3 & 0 & 19 & 884 & 903 \\
\hline AY & 1757 & 203 & o & 0 & 0 & 825 & 817 & $\mathbf{0}$ & 0 & 0 & 0 & 1642 & 0 & 115 & 0 & 115 \\
\hline$A Z$ & 1929 & 31 & 1799 & 0 & 0 & 0 & 0 & 0 & 0 & 0 & 0 & 1799 & 0 & 130 & 0 & 130 \\
\hline B & 2057 & $\mathbf{0}$ & 0 & 0 & 0 & 0 & 0 & 0 & 0 & 0 & 15 & 15 & 0 & 1697 & 345 & 2042 \\
\hline$B X$ & 1559 & 0 & 0 & 0 & 0 & 0 & 0 & 0 & 0 & 0 & 50 & 50 & 0 & 1354 & 155 & 1509 \\
\hline BY & 4744 & 0 & 0 & $\mathbf{0}$ & 0 & 0 & 0 & 0 & 0 & 0 & 0 & 0 & 0 & 719 & 4025 & 4744 \\
\hline C & 2146 & 0 & 0 & 0 & 0 & 0 & 0 & 0 & 0 & 0 & 169 & 169 & 0 & 1977 & 0 & 1977 \\
\hline of & < $4 \%$ & $201 \%$ & $\%$ & 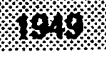 & 6 & 826 & 10120 & \%ol & \% & $1.9 \%$ & 28 & $2000 \%$ & 134 & $820 \%$ & $65 \%$ & 15720 \\
\hline 1\% & & & & & & & & & & & & & & & & \\
\hline $\mathbf{s}$ & 5680 & 0 & 0 & $\mathbf{0}$ & 0 & 0 & 0 & 0 & $\mathbf{0}$ & 17 & 29 & 46 & 0 & 1171 & 4463 & 5634 \\
\hline sx & 4453 & 0 & 0 & 0 & 0 & 1 & 0 & 0 & $\mathbf{0}$ & 0 & 62 & 63 & 0 & 1532 & 2858 & 4390 \\
\hline SY & 2593 & 827 & 0 & 197 & 0 & 0 & 0 & 0 & 658 & 0 & 0 & 855 & 1103 & 71 & 564 & 1738 \\
\hline$T$ & 2034 & 0 & 0 & 0 & 0 & 0 & 0 & 0 & 0 & 0 & 45 & 45 & 0 & 1989 & 0 & 1989 \\
\hline$T X$ & 6905 & 0 & 0 & 0 & 0 & 0 & 0 & 0 & 0 & 0 & 5 & 5 & 0 & 241 & 6659 & 6900 \\
\hline $\mathrm{TY}$ & 638 & 0 & 0 & 0 & 0 & 0 & 0 & 0 & 0 & 0 & 3 & 3 & 0 & 571 & 64 & 635 \\
\hline $\mathbf{U}$ & 3550 & 0 & 0 & 0 & 0 & 0 & 0 & 0 & 0 & 31 & 137 & 168 & 0 & 638 & 2744 & 3382 \\
\hline of & \%ol $6 x$ & $\%$ & 8 & $\$ 9 \%$ & 8 & 格 & 80 & 6 & $65 \%$ & $\%$ & 801 & 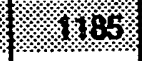 & $\% 0 \%$ & 6218 & $1 \% 4 \%$ & 24668 \\
\hline 6851 & xys obv & 梦: & s. & 346 & 楚6 & $8 \%$ & $301 \%$ & 96 & xos & 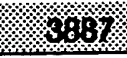 & 8 & $82,2 \%$ & 2010 & x. 440 & 23029 & 10388 \\
\hline
\end{tabular}


TABLE E-4. INVENTORY AND STATUS BY TANK DOUBLE-SHELL TANKS

$$
\text { July } 1993
$$

\begin{tabular}{|c|c|c|c|c|c|c|c|c|c|c|c|c|c|c|c|c|c|}
\hline & TANK & STATUS & & & & & LIOUIO V & OLUKE & & & & SOLIDS VOLLHE & vo & OLUME & DETERHI & TION & \\
\hline & $\begin{array}{l}\text { WASTE } \\
\text { MATL }\end{array}$ & $\begin{array}{l}\text { TANK } \\
\text { INTEGRTY }\end{array}$ & $\begin{array}{l}\text { TANK } \\
\text { USE }\end{array}$ & $\begin{array}{l}\text { EQUIVA- } \\
\text { LENT } \\
\text { WASTE } \\
\text { INCHES }\end{array}$ & $\begin{array}{l}\text { TOTAL } \\
\text { WASTE } \\
\text { (Kgal) }\end{array}$ & $\begin{array}{l}\text { SUPER- } \\
\text { AVAIL MATAMT } \\
\text { SPACE LIQUID } \\
\text { (Kgal) (Kgal) }\end{array}$ & $\begin{array}{l}\text { DRAIN- } \\
\text { ABLE } \\
\text { INTER- } \\
\text { STIT. } \\
\text { (Kgal) }\end{array}$ & $\begin{array}{l}\text { PUAPED } \\
\text { THIS } \\
\text { MONTH }\end{array}$ & $\begin{array}{l}\text { TOTAL } \\
\text { PUMPED }\end{array}$ & $\begin{array}{l}\text { DRAIN- } \\
\text { ABLE } \\
\text { LIQUID } \\
\text { REMAIN } \\
\text { (Kgal) }\end{array}$ & $\begin{array}{l}\text { PUIAP- } \\
\text { ABLE } \\
\text { LIQUID } \\
\text { REMAIN } \\
\text { (Kgal) }\end{array}$ & $\begin{array}{r}\text { SALT } \\
\text { DSS SLDG CAKE } \\
\text { (Kgallons) }\end{array}$ & $\begin{array}{l}\text { LIO } \\
\text { VOL } \\
\text { MTHD }\end{array}$ & $\begin{array}{l}\text { SOL } \\
\text { VOL } \\
\text { MTHD }\end{array}$ & $\begin{array}{l}\text { SOLIDS } \\
\text { VOLUME } \\
\text { UPDATE }\end{array}$ & $\begin{array}{l}\text { LAST } \\
\text { PHOTO } \\
\text { DATE }\end{array}$ & $\begin{array}{l}\text { CHANGE } \\
\text { SINCE } \\
\text { LAST } \\
\text { MONTHLY } \\
\text { REPORT }\end{array}$ \\
\hline
\end{tabular}

\begin{tabular}{|c|c|c|c|c|c|c|c|c|c|c|c|c|c|c|c|c|c|c|}
\hline & & & & & & & ++++++ AN & FARM & STATUS & $+t++t+$ & & & & & & & & \\
\hline$A N-101$ DN & sound & DRCYR & 232.7 & 640 & 500 & 640 & o & 0.0 & 0.0 & 640 & 640 & 0 & 0 & o & $\mathbf{F M}$ & $\mathbf{s}$ & $08 / 22 / 89$ & $0 / 0 / 0$ \\
\hline AN-102 CC & sound & CUHT & 400.4 & 1101 & 39 & 1012 & 3 & 0.0 & 0.0 & 1015 & 1012 & 0 & 89 & o & $\mathbf{F M}$ & $\mathbf{s}$ & 08/22/89 & $0 / 0 / 0$ \\
\hline AN-103 DSS & SOUNO & СUHт & 345.8 & 951 & 189 & 14 & 0 & 0.0 & 0.0 & 14 & 14 & 937 & 0 & o & $\mathbf{F M}$ & $\mathbf{s}$ & 08/22/89 & $10 / 29 / 87$ \\
\hline AN-104 DSSF & SOUND & CUHT & 386.9 & 1064 & 76 & 800 & 25 & 0.0 & 0.0 & 825 & 803 & 0 & 264 & 0 & FH & $\mathbf{s}$ & $08 / 22 / 89$ & $08 / 19 / 88$ \\
\hline AN-105 DSSF & sound & СUHт & 410.5 & 1129 & 11 & 1129 & 0 & 0.0 & 0.0 & 1129 & 1129 & 0 & 0 & 0 & $\mathbf{F M}$ & $\mathbf{s}$ & $10 / 22 / 84$ & $01 / 26 / 88$ \\
\hline AN-106 CP & SOUND & СUнт & 8.4 & 23 & 1117 & 6 & 0 & 0.0 & 0.0 & 6 & 6 & 0 & 17 & 0 & $\mathbf{F M}$ & $\mathbf{s}$ & $08 / 22 / 89$ & $0 / 0 / 0$ \\
\hline$A N-107 C C$ & SOUND & СИнт & 388.4 & 1068 & 72 & 934 & 9 & 0.0 & 0.0 & 943 & 934 & 0 & 134 & 0 & $\mathbf{F M}$ & $\mathbf{s}$ & 08/22/89 & $09 / 01 / 88$ \\
\hline \multirow[t]{2}{*}{7 DOUBLE-SHELL } & L TAMKS & & TOTALS: & 5976 & 2004 & 4535 & 37 & 0.0 & 0.0 & 4572 & 4538 & 937 & 504 & 0 & & & & \\
\hline & & & & & & & t++t++t AP & FARM & StATUS & $+++++t$ & & & & & & & & \\
\hline$A P-101 D N$ & SOUHD & DRCVR & 385.8 & 1061 & 79 & 1061 & 0 & 0.0 & 0.0 & 1061 & 1061 & 0 & 0 & 0 & $\mathbf{F M}$ & $\mathbf{s}$ & $05 / 01 / 89$ & $0 / 0 / 0$ \\
\hline AP-102 DN & SOUND & GRTFD & 402.5 & 1107 & 33 & 1107 & 0 & 0.0 & 0.0 & 1107 & 1107 & 0 & o & 0 & $\mathbf{F M}$ & $\mathbf{s}$ & $07 / 11 / 89$ & $0 / 0 / 0$ \\
\hline$A P-103$ DN & SOUND & DRCVR & 412.0 & 1133 & 7 & 1133 & 0 & 0.0 & 0.0 & 1133 & 1133 & o & 0 & 0 & $\mathbf{F M}$ & $\mathbf{s}$ & $10 / 13 / 88$ & $0 / 0 / 0$ \\
\hline AP-104 DN & SOUND & GRTFD & 6.9 & 19 & 1121 & 19 & 0 & 0.0 & 0.0 & 19 & 19 & 0 & 0 & 0 & $\mathbf{F M}$ & $\mathbf{s}$ & $10 / 13 / 88$ & $0 / 0 / 0$ \\
\hline AP- 105 DSSF & SOUND & СИнт & 298.5 & 821 & 319 & 821 & 0 & 0.0 & 0.0 & 821 & 821 & 0 & 0 & 0 & $\mathbf{F M}$ & $\mathbf{s}$ & $02 / 02 / 89$ & $0 / 0 / 0$ \\
\hline AP-106 DN & SOUND & DRCVR & 410.5 & 1129 & 11 & 1129 & 0 & 0.0 & 0.0 & 1129 & 1129 & o & 0 & 0 & FM & s & $10 / 13 / 88$ & $0 / 0 / 0$ \\
\hline AP-107 DN & SOUND & DRCVR & 405.5 & 1115 & 25 & 1115 & 0 & 0.0 & 0.0 & 1115 & 1115 & 0 & 0 & 0 & $\mathbf{F M}$ & $\mathbf{s}$ & $10 / 13 / 88$ & $0 / 0 / 0$ \\
\hline$A P-108$ DN & SOUND & DRCVR & 328.0 & 902 & 238 & 902 & 0 & 0.0 & 0.0 & 902 & 902 & 0 & 0 & 0 & $\mathbf{F M}$ & $\mathbf{s}$ & $10 / 13 / 88$ & $0 / 0 / 0$ \\
\hline 8 DOUBLE-SHELL & NKS & & TOTALS: & 7287 & 1833 & 7287 & 0 & 0.0 & 0.0 & 7287 & 7287 & 0 & 0 & 0 & & & & \\
\hline
\end{tabular}


TABLE E-4. INVENTORY AND STATUS BY TANK DOUBLE-SHELL TANKS

$$
\text { July } 1993
$$

\begin{tabular}{|c|c|c|c|c|c|c|c|c|c|c|c|c|c|c|c|c|c|}
\hline & TAMI & status & & & & & LIOUID V & OLUME & & & & SOLIDS VOLUME & & OLUNE & DETERMI & TION & \\
\hline ANK & $\begin{array}{l}\text { MASTE } \\
\text { MATL }\end{array}$ & $\begin{array}{l}\text { TAMK } \\
\text { INTEGRTY }\end{array}$ & $\begin{array}{l}\text { TANK } \\
\text { USE }\end{array}$ & $\begin{array}{l}\text { EQUIVA- } \\
\text { LENT } \\
\text { WASTE } \\
\text { INCHES }\end{array}$ & $\begin{array}{l}\text { TOTAL } \\
\text { WASTE } \\
\text { (Kgal) }\end{array}$ & $\begin{array}{l}\text { SUPER- } \\
\text { AVAIL MATANT } \\
\text { SPACE LIOUID } \\
\text { (Kgal)(Kgal) }\end{array}$ & $\begin{array}{l}\text { DRAIN- } \\
\text { ABLE } \\
\text { INIER- } \\
\text { STIT. } \\
\text { (Kgal) }\end{array}$ & $\begin{array}{l}\text { PUWPED } \\
\text { THIS } \\
\text { MONTH }\end{array}$ & $\begin{array}{l}\text { TOTAL } \\
\text { PUMPED }\end{array}$ & $\begin{array}{l}\text { DRAIN- } \\
\text { ABLE } \\
\text { LIOUID } \\
\text { REMAIN } \\
\text { (Kgal) }\end{array}$ & $\begin{array}{l}\text { PLARP- } \\
\text { ABLE } \\
\text { LIOUID } \\
\text { REMAIN } \\
\text { (Kgal) }\end{array}$ & $\begin{array}{r}\text { SALT } \\
\text { DSS SLDG CAKE } \\
\text { (Kgallons) }\end{array}$ & $\begin{array}{l}\text { LIO } \\
\text { VOL } \\
\text { MTHD }\end{array}$ & $\begin{array}{l}\text { SOL } \\
\text { VOL } \\
\text { MTHD }\end{array}$ & $\begin{array}{l}\text { SOLIDS } \\
\text { VOLUIE } \\
\text { UPDATE }\end{array}$ & $\begin{array}{l}\text { LAST } \\
\text { PHOTO } \\
\text { DATE }\end{array}$ & $\begin{array}{l}\text { CHANGE } \\
\text { SINCE } \\
\text { LAST } \\
\text { MONTHLY } \\
\text { REPORT }\end{array}$ \\
\hline
\end{tabular}

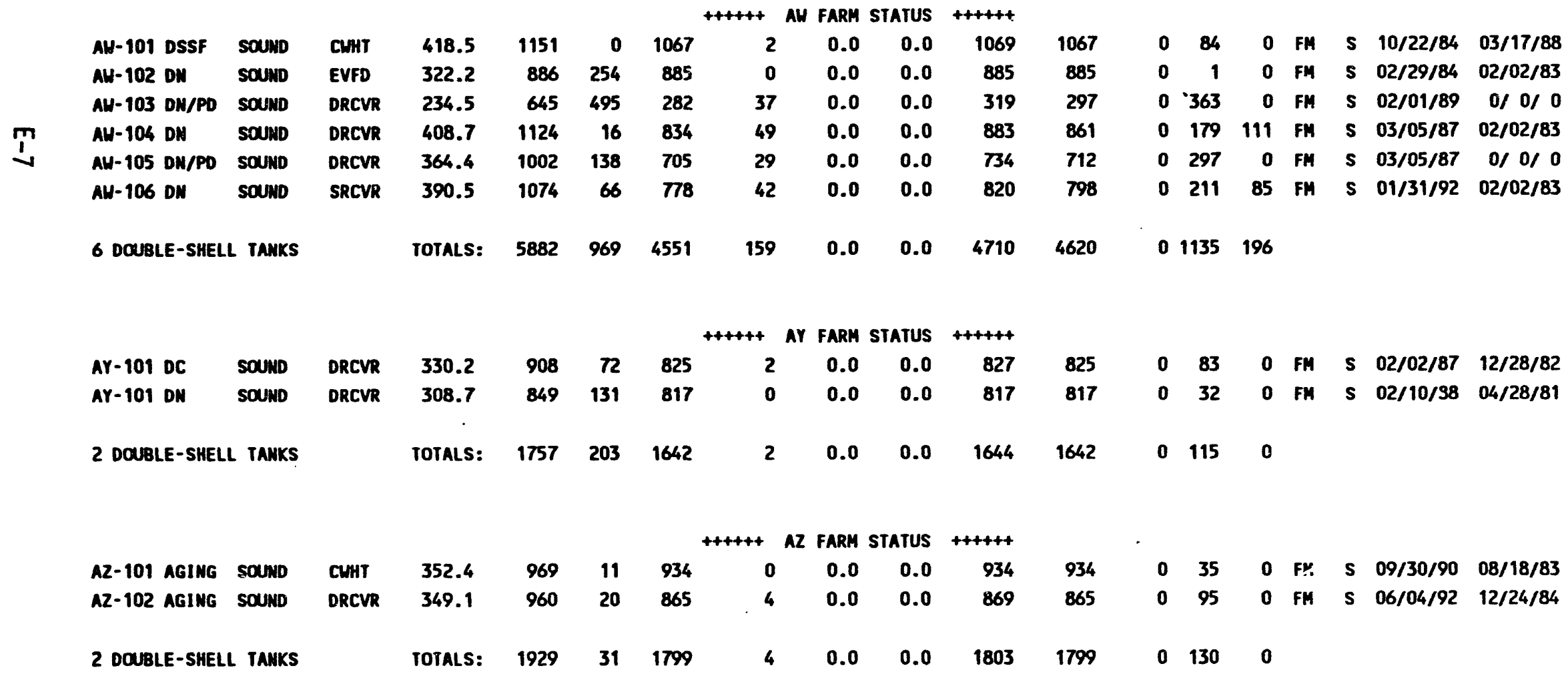


TABLE E-4. INVENTORY AND STATUS BY TANK

DOUBLE-SHELL TANKS

July 1993

TANK STATUS

MASTE TANK TANK
TAMK MATL INTEGRTY USE

LIOUID VOLUME

\begin{tabular}{|c|c|c|c|c|c|c|c|c|}
\hline EQUIVA- & & & SUPER- & $\begin{array}{l}\text { DRAIN- } \\
\text { ABLE } \\
\text { LUTER- }\end{array}$ & & & $\begin{array}{l}\text { DRAIN- } \\
\text { ABLE } \\
\text { LOUID }\end{array}$ & $\begin{array}{l}\text { PUMP- } \\
\text { ABLE } \\
\text { LOUID }\end{array}$ \\
\hline $\begin{array}{l}\text { LENT } \\
\text { WASTE } \\
\text { INCHES }\end{array}$ & $\begin{array}{l}\text { TOTAL } \\
\text { UASTE } \\
\text { (Kgal) }\end{array}$ & $\begin{array}{l}\text { SPACE } \\
\text { (Kgal }\end{array}$ & $\begin{array}{l}\text { LATANT } \\
\text { (Kgal) }\end{array}$ & $\begin{array}{l}\text { STIT. } \\
\text { (Kgal) }\end{array}$ & $\begin{array}{l}\text { PUIPED } \\
\text { THIS } \\
\text { MONTH }\end{array}$ & $\begin{array}{l}\text { TOTAL } \\
\text { PUMPED }\end{array}$ & $\begin{array}{l}\text { REMAIN } \\
\text { (Kgal) }\end{array}$ & $\begin{array}{l}\text { REMAIN } \\
\text { (Kgal) }\end{array}$ \\
\hline
\end{tabular}

\section{SOLIDS VOLUME VOLUME DETERMIMATION}

SOLIDS VOLU

SINCE

SALT LIQ SOL SOLIDS LAST LAST

DSS SLDG CAKE VOL VOL VOLUME PHOTO MONTHLY (Kgallons) MTHO MTHD UPDATE DATE REPORT

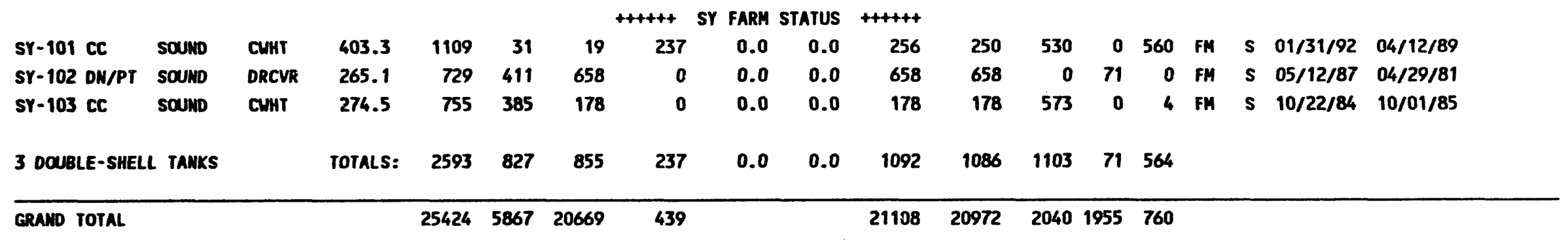

Note: $+1-1 \mathrm{Kgal}$ differences are the result of computer rounding

\begin{tabular}{|c|c|c|c|c|}
\hline \multirow[b]{2}{*}{ Tank Farns } & \multirow{2}{*}{$\begin{array}{l}\text { Available Space } \\
\text { Calculations Used } \\
\text { In This Document } \\
\text { (Most Conservative) }\end{array}$} & \multicolumn{2}{|c|}{ Document SD-MA-TI-357* } & \multirow{2}{*}{$\begin{array}{l}\text { Dociment } \\
\text { OSD-T-151-00007** } \\
\text { Specification Limit }\end{array}$} \\
\hline & & Opersting Limit & Tank Capacity & \\
\hline $\begin{array}{l}\text { AN, AP, AM, SY } \\
\text { AY, AZ (Aging Waste) }\end{array}$ & $\begin{array}{r}1,140,000 \mathrm{gal}(414.5 \mathrm{in.}) \\
980,000 \mathrm{gal}(356.4 \mathrm{in.})\end{array}$ & $\begin{array}{r}1,144,000 \text { gal }: 416 \text { in. }) \\
990,000 \text { gal (360 in.) }\end{array}$ & $\begin{array}{l}1,160,000 \mathrm{gal}(421.8 \mathrm{in.}) \\
1,000,000 \mathrm{gal}(363.6 \mathrm{in.})\end{array}$ & $\begin{array}{l}1,160,500 \mathrm{gal} \text { (422 in.) } \\
1,001,000 \mathrm{gal}(364 \mathrm{in.})\end{array}$ \\
\hline
\end{tabular}

* WHC-SD-LM-TI-357, "Waste Storage Tank Status and Leak Detection Criteria."

* \#HC-0SD-T-151-00007, "Operating Specifications for 241-AN, AP, AH, AY, AZ, \& SY Tank Farms."

(1) Tank AW-101: Although the total waste exceeds the $1140 \mathrm{Kgal}$ specified for waste volume projections of available space, it does not exceed the operating limit criteria. 
TABLE E-5. INVENTORY AND STATUS BY tANK

SIMGLE-SHELL TANKS

July 1993

\begin{tabular}{|c|c|c|c|c|c|c|c|c|c|c|c|c|c|c|c|c|c|c|}
\hline & TANK ST & tatus & & & & LIOUIO & VOLUME & & & & SOLIDS & VOLUME & & VOLU & E DETERM & IMATION & & \\
\hline$K$ & $\begin{array}{l}\text { WASTE } \\
\text { MATERIAL }\end{array}$ & $\begin{array}{l}\text { TANK } \\
\text { INTEGRITY }\end{array}$ & $\begin{array}{l}\text { STABIL/ } \\
\text { ISOLATION } \\
\text { STATUS }\end{array}$ & $\begin{array}{r}\text { TOTAL } \\
\text { MASTE } \\
\text { (Kgal) }\end{array}$ & $\begin{array}{l}\text { SUPER- } \\
\text { MATANT } \\
\text { LIOUID } \\
\text { (Kgal) }\end{array}$ & $\begin{array}{l}\text { DRAIN- } \\
\text { ABLE } \\
\text { INTER- } \\
\text { STII. } \\
\text { (k.gal) }\end{array}$ & $\begin{array}{l}\text { PUMPED } \\
\text { THIS } \\
\text { MONTH } \\
\text { (Kgal) }\end{array}$ & $\begin{array}{l}\text { TOTAL } \\
\text { PUMPED } \\
\text { (Kgal) }\end{array}$ & $\begin{array}{l}\text { DRAIN- } \\
\text { ABLE } \\
\text { LIOUID } \\
\text { REMAIN } \\
\text { (Kgal) }\end{array}$ & $\begin{array}{l}\text { PUMP- } \\
\text { ABLE } \\
\text { LIQUID } \\
\text { REMAIN } \\
\text { (Kgal) }\end{array}$ & $\begin{array}{l}\text { SLUDGE } \\
\text { (Kgal) }\end{array}$ & $\begin{array}{l}\text { SALTCAKE } \\
\text { (Kgal) }\end{array}$ & $\begin{array}{l}\text { LICUIDS } \\
\text { VOLUYE } \\
\text { METHOO }\end{array}$ & $\begin{array}{l}\text { SOLIDS } \\
\text { VOLUME } \\
\text { METHOD }\end{array}$ & $\begin{array}{l}\text { SOLIDS } \\
\text { VOLUME } \\
\text { UPDATE }\end{array}$ & $\begin{array}{l}\text { SOLIDS } \\
\text { UPDATE } \\
\text { SOURCE } \\
\text { SEE } \\
\text { FOOTMOTE }\end{array}$ & $\begin{array}{l}\text { LAST } \\
\text { PHOTO } \\
\text { DATE }\end{array}$ & $\begin{array}{l}\text { CHG } \\
\text { SINCE } \\
\text { LAST } \\
\text { MNTHLY } \\
\text { REPORT }\end{array}$ \\
\hline
\end{tabular}

\begin{tabular}{|c|c|c|c|c|c|c|c|c|c|c|c|c|c|c|c|c|c|}
\hline & & & & & & +++1 & A FARM $S$ & TRTUS & $t++t+t$ & & & & & & & & \\
\hline$A-101$ & DSSF & SOUND & $|P|$ & 953 & 0 & 413 & 0.0 & 0.0 & 413 & 390 & 3 & 950 & $\mathbf{P}$ & $\mathbf{F}$ & $11 / 21 / 80$ & & $08 / 21 / 85$ \\
\hline$A-102$ & DSSF & SOUND & IS/PI & 41 & 4 & 2 & 0.0 & 39.5 & 6 & 0 & 15 & 22 & $\mathbf{P}$ & $\mathbf{F P}$ & $07 / 27 / 89$ & (1) & $07 / 20 / 89$ \\
\hline A-103 & DSSF & ASID LKR & IS/IP & 370 & 4 & 13 & 0.0 & 111.0 & 12 & 0 & 366 & 0 & $\cdot$ & FP & $06 / 03 / 88$ & (1) & $12 / 28 / 88$ \\
\hline A-104 & MCPLX & ASHD LKR & IS/IP & 28 & 0 & 0 & 0.0 & 0.0 & 0 & 0 & 28 & $\mathbf{0}$ & M & PS & $01 / 27 / 78$ & & $06 / 25 / 86$ \\
\hline A. 105 & MCPLX & ASHD LKR & IS/IP & 19 & 0 & 4 & 0.0 & 0.0 & 4 & 0 & 19 & 0 & $\mathbf{P}$ & MP & $08 / 23 / 79$ & (1) & $08 / 20 / 86$ \\
\hline$A-106$ & CP & SOUND & IS/IP & 125 & 0 & 7 & 0.0 & 0.0 & 7 & 0 & 125 & o & $\mathbf{P}$ & $M$ & $09 / 07 / 82$ & & $08 / 17 / 86$ \\
\hline 6 SINGL & ILE-SHELL & TANKS & TOTALS & 1536 & 8 & 439. & 0.0 & 150.5 & 442 & 390 & 556 & 972 & & & & & \\
\hline & & & & & & $+t+$ & AX FARY & STATUS & $+++t+t$ & & & & & & & & \\
\hline$a x-101$ & DSSF & SOUND & IPI & 748 & 0 & 320 & 0.0 & 0.0 & 320 & 298 & 3 & 745 & $\mathbf{P}$ & $F$ & $05 / 06 / 82$ & & $08 / 18 / 87$ \\
\hline$A x-102$ & CC & ASHD LKR & IS/IP & 39 & 3 & 14 & 0.0 & 13.0 & 17 & 3 & 7 & 29 & $\mathbf{F}$ & $\mathbf{S}$ & $09 / 06 / 88$ & & $06 / 05 / 89$ \\
\hline$A x-103$ & CC & SOUND & IS/IP & 112 & 0 & 36 & 0.0 & 0.0 & 36 & 3 & 2 & 110 & $\mathbf{F}$ & $\mathbf{s}$ & $08 / 19 / 87$ & & $08 / 13 / 87$ \\
\hline$A x-104$ & MCPLX & ASHD LKR & IS/IP & 7 & $\mathbf{0}$ & 0 & 0.0 & 0.0 & 0 & 0 & 7 & 0 & $\mathbf{P}$ & $M$ & $04 / 28 / 82$ & & $08 / 18 / 87$ \\
\hline 4 SINGL & LE-SHELL & TANKS & TOTALS: & 906 & 3 & 370 & 0.0 & 13.0 & 373 & 304 & 19 & 884 & & & & & \\
\hline
\end{tabular}


TABLE E-5. INVENTORY AND STATUS BY TANK

SIMGLE-SHELL TAMKS

July 1993

TANK STATUS

MASTE TANK

TAHK MATERIAL IOAKK ISOLATION WASTE LIOUID STIT. MONTH PU B.t++t+ B FARM STATUS ++++++

\begin{tabular}{|c|c|c|c|c|c|c|c|c|c|c|c|c|c|c|c|c|c|}
\hline B-101 & MCPLX & ASND LKR & IS/IP & 113 & 0 & $\begin{array}{r}+++ \\
6\end{array}$ & $\begin{array}{c}A R M S \\
0.0\end{array}$ & $\begin{array}{l}\text { TUS } \\
0.0\end{array}$ & 6 & 0 & 113 & $\mathbf{0}$ & $\mathbf{P}$ & $\mathbf{F}$ & $04 / 28 / 82$ & & $05 / 19 / 83$ \\
\hline B-102 & MCPLX & SOUND & IS/IP & 32 & 4 & 0 & 0.0 & 0.0 & 4 & 0 & 18 & 10 & P & $\mathbf{F}$ & $08 / 22 / 85$ & (1) & $08 / 22 / 85$ \\
\hline B- 103 & MCPLX & ASYD LKR & IS/IP & 59 & 0 & 0 & 0.0 & 0.0 & 0 & 0 & 59 & 0 & $\mathbf{F}$ & $\mathbf{F}$ & $02 / 28 / 85$ & (1) & $10 / 13 / 88$ \\
\hline B- 104 & NCPLX & SOUND & IS/IP & 371 & 1 & 46 & 0.0 & 0.0 & 47 & 40 & 301 & 69 & M & M & $06 / 30 / 85$ & (1) & $10 / 13 / 88$ \\
\hline B-105 & MCPLX & ASMD LKR & IS/IP & 306 & 0 & 23 & 0.0 & 0.0 & 23 & 0 & 40 & 266 & $\mathbf{P}$ & MP & $12 / 27 / 84$ & (1) & $05 / 19 / 88$ \\
\hline B-106 & NCPLX & SOUND & IS/IP & 117 & 1 & 6 & 0.0 & 0.0 & 7 & 0 & 116 & 0 & $\mathbf{F}$ & $\mathbf{F}$ & $03 / 31 / 85$ & (1) & $02 / 28 / 85$ \\
\hline$B-107$ & MCPLX & ASUD LKR & IS/IP & 165 & 1 & 12 & 0.0 & 0.0 & 13 & 7 & 164 & 0 & $M$ & H & $03 / 31 / 85$ & (1) & $02 / 28 / 85$ \\
\hline$B-108$ & MCPLX & sourd & IS/IP & 94 & 0 & 4 & 0.0 & 0.0 & 4 & 0 & 94 & 0 & $\mathbf{F}$ & $\mathbf{F}$ & $05 / 31 / 85$ & (1) & $05 / 10 / 85$ \\
\hline B-109 & MCPLXX & sound & IS/IP & 127 & $\mathbf{0}$ & 8 & 0.0 & 0.0 & 8 & 0 & 127 & 0 & $M$ & $M$ & $04 / 08 / 85$ & (1) & $04 / 02 / 85$ \\
\hline$B-110$ & MCPLX & ASID LKR & IS/IP & 246 & 1 & 22 & 0.0 & 0.0 & 23 & 17 & 245 & 0 & MP & MP & $02 / 28 / 85$ & (1) & $03 / 17 / 88$ \\
\hline B-111 & MCPLX & ASHD LKR & IS/IP & 237 & 1 & 21 & 0.0 & 0.0 & 22 & 16 & 236 & 0 & $\mathbf{F}$ & $\mathbf{F}$ & $06 / 28 / 85$ & (1) & $06 / 26 / 85$ \\
\hline$B-112$ & NCPLX & ASWD LKR & IS/IP & 33 & 3 & $\mathbf{0}$ & 0.0 & 0.0 & 3 & 0 & 30 & 0 & $\mathbf{F}$ & $\mathbf{F}$ & $05 / 31 / 85$ & (1) & $05 / 29 / 85$ \\
\hline$B-201$ & MCPLX & ASMD LKR & IS/IP & 29 & 1 & 3 & 0.0 & 0.0 & 4 & 0 & 28 & 0 & $M$ & M & $04 / 28 / 82$ & & $11 / 12 / 86$ \\
\hline$B-202$ & NCPLX & SOUND & $I S / I P$ & 27 & 0 & 3 & 0.0 & 0.0 & 3 & 0 & 27 & 0 & $P$ & $M$ & $05 / 31 / 85$ & (1) & $05 / 29 / 85$ \\
\hline$B-203$ & MCPLXX & ASMD IKR & IS/IP & 51 & 1 & 5 & 0.0 & 0.0 & 6 & 0 & 50 & 0 & PM & PM & $05 / 31 / 84$ & (1) & $11 / 13 / 86$ \\
\hline$B-204$ & MCPLX & ASHD LKR & IS/IP & 50 & 1 & 5 & 0.0 & 0.0 & 6 & 0 & 49 & 0 & $\mathbf{P}$ & $M$ & $05 / 31 / 84$ & (1) & $10 / 21 / 87$ \\
\hline $16 \mathrm{SIN}$ & GLE-SHE & TANKS & TOTALS & 2057 & 15 & 164 & 0.0 & 0.0 & 179 & 80 & 1697 & 345 & & & & & \\
\hline
\end{tabular}

VOLUME DETERMINATION

\begin{tabular}{|c|c|c|c|c|c|}
\hline & & & SOLIDS & & CHG \\
\hline & & & UPDATE & & SIMCE \\
\hline LIOUIDS & SOLIDS & SOLIDS & SOURCE & LAST & LAST \\
\hline VOLUNE & VOLUME & VOLUME & SEE & PHOTO & MNTHLY \\
\hline METHOD & METHOD & UPDATE & FOOTMOTE & DATE & REPORT \\
\hline
\end{tabular}


tABLE E-5. InVENTORY AMd STATUS BY TANK

SINGLE-SHELL TANKS

July 1993

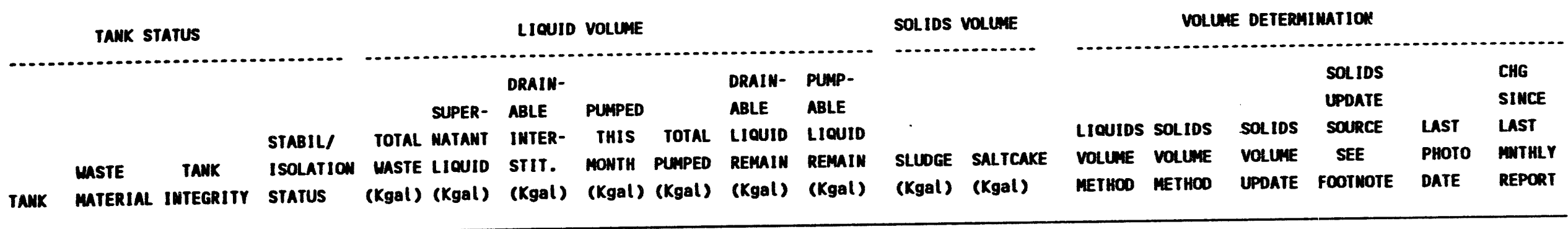

\begin{tabular}{|c|c|c|c|c|c|c|c|c|c|c|c|c|c|c|c|c|}
\hline & & & & & $r++$ & BX FARM S & status & $+++++t$ & & & & & & & & \\
\hline$B X-101$ NCPLX & ASID LKR & IS/IP & 43 & 1 & 0 & 0.0 & 0.0 & 1 & 0 & 42 & 0 & $\mathbf{P}$ & $\mathbf{M}$ & $04 / 28 / 82$ & & $11 / 24 / 88$ \\
\hline $8 X-102$ NCPLX & ASID LKR & IS/IP & 96 & 0 & 4 & 0.0 & 0.0 & 4 & $\mathbf{0}$ & 96 & 0 & $\mathbf{P}$ & M & $04 / 28 / 82$ & & $09 / 18 / 85$ \\
\hline$B X-103$ NCPLX & Sound & IS/IP & 66 & 4 & 0 & 0.0 & 0.0 & 4 & $\mathbf{0}$ & 62 & 0 & $\mathbf{P}$ & $\mathbf{F}$ & $11 / 29 / 83$ & & $10 / 31 / 86$ \\
\hline BX-104 NCPLX & SOUMD & IS/IP & 99 & 3 & 30 & 0.0 & 17.4 & 33 & 27 & 96 & 0 & $\mathbf{F}$ & $\mathbf{F}$ & $09 / 22 / 89$ & (1) & $09 / 21 / 89$ \\
\hline$B X-105$ NCPLX & SOUnd & IS/IP & 51 & 5 & 6 & 0.0 & 15.0 & 11 & 4 & 43 & 3 & $\mathbf{F}$ & $\mathbf{s}$ & $09 / 03 / 86$ & (1) & $10 / 23 / 86$ \\
\hline BX-106 MCPLX & Sound & IPI & 46 & 15 & 0 & 0.0 & 0.0 & 15 & 15 & 31 & $\mathbf{0}$ & $\mathbf{M P}$ & PS & $04 / 28 / 82$ & & $05 / 19 / 88$ \\
\hline$B X-107$ MCPLX & SOUnd & IS/PI & 345 & 1 & 29 & 0.0 & 23.1 & 30 & 23 & 344 & 0 & MP & $\mathbf{P}$ & $09 / 18 / 90$ & (2) & $09 / 11 / 90$ \\
\hline BX-108 NCPLX & ASHD LKR & IS/IP & 26 & 0 & 1 & 0.0 & 0.0 & 1 & 0 & 26 & 0 & $\mathbf{M}$ & PS & $07 / 31 / 79$ & (1) & $10 / 23 / 86$ \\
\hline $8 X-109$ MCPLX & SOUND & $|S / P|$ & 193 & 0 & 13 & 0.0 & 8.2 & 13 & 8 & 193 & 0 & FP & $\mathbf{P}$ & $09 / 17 / 90$ & (2) & $09 / 11 / 90$ \\
\hline BX-110 MCPLX & ASWD LKR & IS/PI & 199 & 1 & 15 & 0.0 & 0.0 & 16 & 10 & 189 & 9 & $\operatorname{MP}$ & H & $08 / 22 / 85$ & (1) & $07 / 31 / 85$ \\
\hline$B X-111$ NCPLX & ASMD LKR & API & 230 & 19 & 50 & 0.0 & 0.0 & 69 & 46 & 68 & 143 & $\boldsymbol{M}$ & $M$ & $07 / 26 / 77$ & & $07 / 16 / 93$ \\
\hline$B X-112$ NCPLX & SOUND & IS/PI & 165 & 1 & 7 & 0.0 & 4.1 & 8 & 2 & 164 & 0 & FP & $\mathbf{P}$ & $09 / 17 / 90$ & (2) & $09 / 11 / 90$ \\
\hline \multirow[t]{2}{*}{12 SIMGLE-SHELL } & TANKS & TOTALS: & 1559 & 50 & 155 & 0.0 & 67.8 & 205 & 135 & 1354 & 155 & & & & & \\
\hline & & & & & +++ & BY FARM & status & $+t+t+t$ & & & & & & & & \\
\hline BY-101 MCPLX & SOUND & IS/IP & 387 & 0 & 5 & 0.0 & 35.8 & 5 & 0 & 109 & 278 & $\mathbf{P}$ & M & $05 / 30 / 84$ & & $09 / 19 / 89$ \\
\hline BY-102 NCPLX & SOUmD & /PI & 341 & 0 & 41 & 0.0 & 123.3 & 41 & 22 & 0 & 341 & MP & $\boldsymbol{M}$ & $08 / 30 / 91$ & (2) & $09 / 11 / 87$ \\
\hline BY-103 NCPLX & ASMD LKR & /PI & 400 & 0 & 160 & 0.0 & 78.5 & 160 & 137 & 5 & 395 & MP & M & $04 / 03 / 90$ & (2) & $09 / 07 / 89$ \\
\hline BY-104 MCPLX & sound & IS/IP & 406 & 0 & 18 & 0.0 & 329.5 & 18 & 0 & 40 & 366 & $\mathbf{P}$ & $M$ & $04 / 28 / 82$ & & $04 / 27 / 83$ \\
\hline BY-105 NCPLX & ASYD LKR & IPI & 503 & 0 & 192 & 0.0 & 0.0 & 192 & 169 & 44 & 459 & $\mathbf{P}$ & $\mathbf{M P}$ & $04 / 28 / 82$ & & $07 / 11 / 86$ \\
\hline BY-106 NCPLX & ASID LKR & $|P|$ & 642 & 0 & 235 & 0.0 & 0.0 & 235 & 213 & 95 & 547 & $\mathbf{P}$ & MP & $04 / 28 / 82$ & & $11 / 04 / 82$ \\
\hline BY-107 NCPLX & ASMD LKR & IS/IP & 266 & 0 & 25 & 0.0 & 56.4 & 25 & 0 & 60 & 206 & $\mathbf{P}$ & MP & $04 / 28 / 82$ & & $10 / 15 / 86$ \\
\hline
\end{tabular}


tABLE E-5. INVENTORY AND STATUS bY tAMK SINGLE-SHELL TAMKS

July 1993

\begin{tabular}{|c|c|c|c|c|c|c|c|c|c|c|c|c|c|c|c|c|c|c|}
\hline & tanK 51 & TATUS & & & & LIOUID & VOLUME & & & & SOLIDS V & MLLUAE & & VOLU & ME DETERMII & IMATIOM & & \\
\hline TANK & $\begin{array}{l}\text { MASTE } \\
\text { MATERIAL }\end{array}$ & $\begin{array}{c}\text { TAMK } \\
\text { INTEGRITY }\end{array}$ & $\begin{array}{l}\text { STABIL/ } \\
\text { ISOLATION } \\
\text { STATUS }\end{array}$ & $\begin{array}{l}\text { TOTAL } \\
\text { WASTE } \\
\text { (Kgal) }\end{array}$ & $\begin{array}{l}\text { SUPER- } \\
\text { MATANT } \\
\text { LIOUID } \\
\text { (Kgal) }\end{array}$ & $\begin{array}{l}\text { DRAIN- } \\
\text { ABLE } \\
\text { INTER- } \\
\text { STIT. } \\
\text { (Kgal) }\end{array}$ & $\begin{array}{l}\text { PUMPED } \\
\text { THIS } \\
\text { MOWTH } \\
\text { (Kgal) }\end{array}$ & $\begin{array}{l}\text { TOTAL } \\
\text { PUMPED } \\
\text { (Kgal) }\end{array}$ & $\begin{array}{l}\text { DRAIN- } \\
\text { ABLE } \\
\text { LIQUID } \\
\text { REMAIn } \\
\text { (Kgal) }\end{array}$ & $\begin{array}{l}\text { PIMP- } \\
\text { ABLE } \\
\text { LIQUID } \\
\text { REMAIN } \\
\text { (Kgal) }\end{array}$ & $\begin{array}{l}\text { SLUDCE } \\
\text { (Kgal) }\end{array}$ & $\begin{array}{l}\text { SALTCAKE } \\
\text { (Kgal) }\end{array}$ & $\begin{array}{l}\text { LIOUIDS } \\
\text { valune } \\
\text { Metroo }\end{array}$ & $\begin{array}{l}\text { SOLIDS } \\
\text { VOLUNE } \\
\text { METHCD }\end{array}$ & $\begin{array}{l}\text { SOLIDS } \\
\text { VOLUAE } \\
\text { UPDATE }\end{array}$ & $\begin{array}{l}\text { SOLIOS } \\
\text { UPDATE } \\
\text { SOURCE } \\
\text { SEE } \\
\text { FOOTWOTE }\end{array}$ & $\begin{array}{l}\text { LAST } \\
\text { PHOTO } \\
\text { DATE }\end{array}$ & $\begin{array}{l}\text { CUG } \\
\text { SIMCE } \\
\text { LAST } \\
\text { mitmLY } \\
\text { REPORT }\end{array}$ \\
\hline$B Y-108$ & MCPLX & ASID LKR & IS/IP & 228 & 0 & 9 & 0.0 & 27.5 & 9 & 0 & 154 & 74 & MP & $M$ & $04 / 28 / 82$ & & $10 / 15 / 86$ & \\
\hline BY -109 & NCPLXX & SOUND & /PI & 423 & 0 & 78 & 0.0 & 93.5 & 78 & 57 & 83 & 340 & $\mathbf{F}$ & PS & $08 / 30 / 91$ & (2) & $10 / 15 / 86$ & \\
\hline BY -110 & MCPLX & sounid & IS/IP & 398 & 0 & 9 & 0.0 & 213.3 & 9 & 0 & 103 & 295 & $\boldsymbol{n}$ & $\mathbf{s}$ & $09 / 10 / 79$ & & $07 / 26 / 84$ & \\
\hline BY-111 & NCPLX & SOUND & IS/IP & 459 & 0 & 0 & 0.0 & 313.2 & 0 & 0 & 21 & 438 & $\mathbf{P}$ & M & $04 / 28 / 82$ & & $10 / 31 / 86$ & \\
\hline BY-112 & MCPLX & SOAnd & IS/IP & 291 & 0 & 8 & 0.0 & 116.4 & 8 & 0 & 5 & 286 & $P$ & $\boldsymbol{M}$ & $04 / 28 / 82$ & & $04 / 14 / 88$ & \\
\hline 12 SING & GLE-SHELL & TANKS & TOTALS: & 4744 & 0 & 780 & 0.0 & 1387.4 & 780 & 598 & 719 & 4025 & & & & & & \\
\hline & & & & & & $t+t+t+$ & C FARM $s$ & STATUS & t+t+t+t & & & & & & & & & \\
\hline$c-101$ & MCPLX & ASID LKR & IS/IP & 88 & 0 & 3 & 0.0 & 0.0 & 3 & 0 & 88 & 0 & $\mathbf{M}$ & $M$ & $11 / 29 / 83$ & & $11 / 17 / 87$ & \\
\hline$C-102$ & DC & SOUND & IPI & 423 & o & 37 & 0.0 & 11.6 & 37 & 19 & 423 & 0 & $\mathbf{F}$ & FP & $04 / 28 / 82$ & & $05 / 18 / 76$ & \\
\hline$c-103$ & $\operatorname{MCPLX}$ & Sound & IPI & 195 & 133 & 0 & 0.0 & 0.0 & 133 & 133 & 62 & 0 & $\mathbf{F}$ & $\mathbf{s}$ & $10 / 22 / 90$ & (2) & $07 / 28 / 87$ & \\
\hline$c-104$ & cc & SOUND & IS/IP & 295 & 0 & 11 & 0.0 & 0.0 & 11 & 5 & 295 & 0 & FP & $\mathbf{P}$ & $09 / 22 / 89$ & (1) & $07 / 25 / 90$ & \\
\hline$c-105$ & MCPLX & SOUMD & IPI & 150 & $\mathbf{0}$ & 11 & 0.0 & 0.0 & 11 & 4 & 150 & 0 & $\mathbf{F}$ & $\mathbf{s}$ & $05 / 31 / 85$ & & $04 / 01 / 88$ & \\
\hline$c-106$ & MCPLX & SOUND & /PI & 229 & 32 & 16 & 0.0 & 0.0 & 48 & 42 & 197 & $\mathbf{0}$ & $F$ & PS & $04 / 28 / 82$ & & $04 / 05 / 79$ & \\
\hline$c-107$ & DC & SOUND & $\mid \mathrm{PI}$ & 275 & 0 & 26 & 0.0 & 16.3 & 26 & 20 & 275 & 0 & 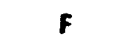 & $\mathbf{s}$ & $01 / 30 / 92$ & (2) & $00 / 00 / 00$ & \\
\hline$c-108$ & MCPLX & SOUND & $15 / 1 P$ & 66 & 0 & 0 & 0.0 & 0.0 & 0 & 0 & 66 & 0 & $n$ & $\mathbf{s}$ & $02 / 24 / 84$ & (1) & $12 / 05 / 74$ & \\
\hline$c-109$ & MCPLXX & SOUND & IS/IP & 66 & 4 & 0 & 0.0 & 0.0 & 4 & 0 & 62 & 0 & M & PS & $11 / 29 / 83$ & & $01 / 30 / 76$ & \\
\hline$C-110$ & DC & ASWD LKR & /PI & 187 & 0 & 7 & 0.0 & 8.9 & 7 & 5 & 187 & 0 & $\mathbf{f}$ & FMP & $03 / 01 / 92$ & (2) & $08 / 12 / 86$ & \\
\hline$c-111$ & MCPLX & ASHD LKR & IS/IP & 57 & 0 & 0 & 0.0 & 0.0 & 0 & 0 & 57 & 0 & $\boldsymbol{M}$ & $\mathbf{s}$ & $04 / 28 / 82$ & & $02 / 25 / 70$ & \\
\hline$C-112$ & MCPLX & SOUND & IS/PI & 104 & 0 & 32 & 0.0 & 0.0 & 32 & 26 & 104 & 0 & $\boldsymbol{M}$ & PS & $09 / 18 / 90$ & (2) & $09 / 18 / 90$ & \\
\hline
\end{tabular}


TABLE E-5, InVENTORY and STATUS BY taMK SIMGLE-SHELL TAMKS

July 1993

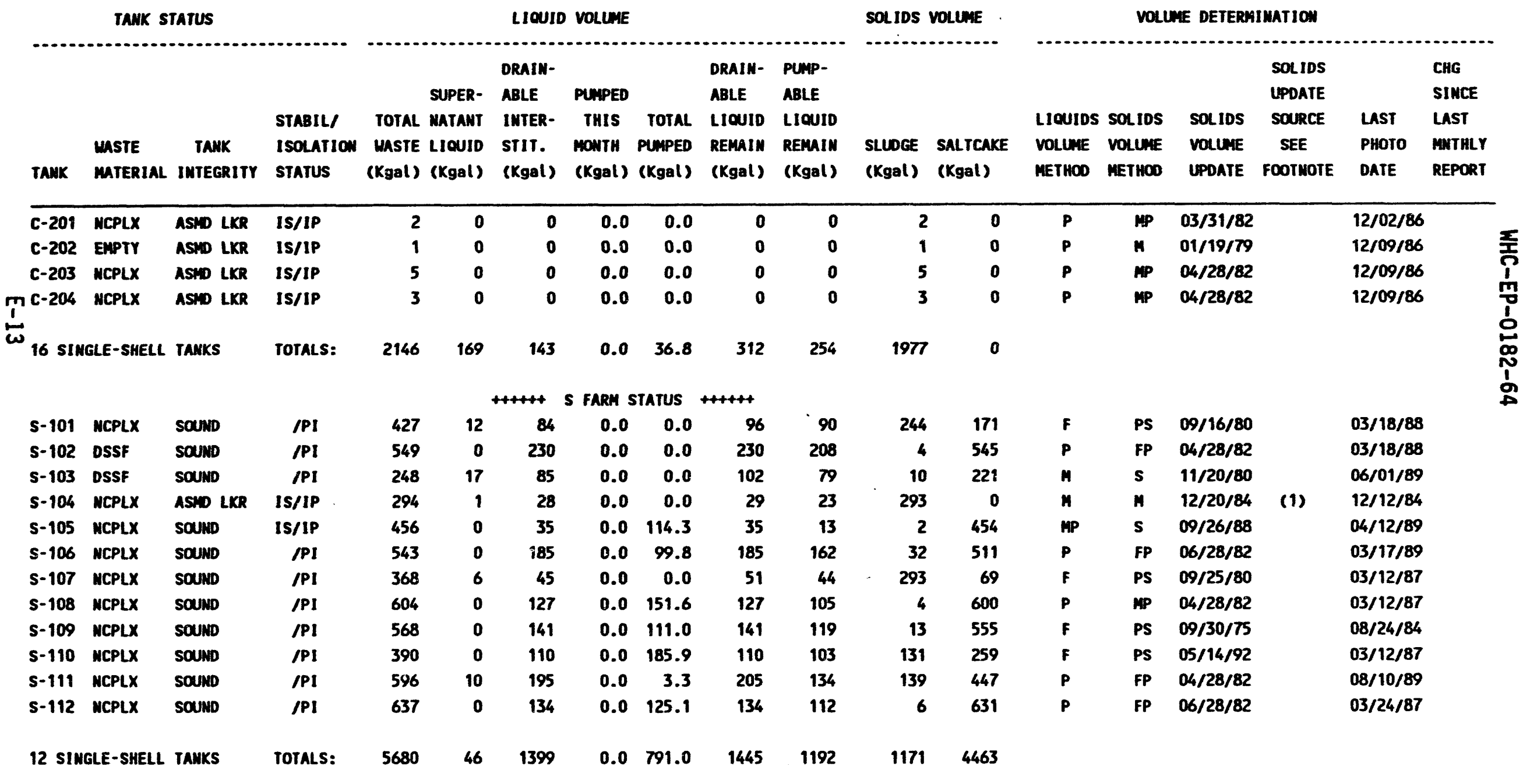

